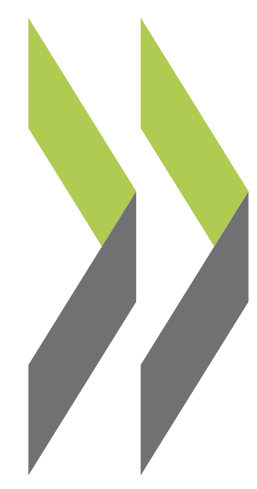

OECD Economics Department Working Papers No. 620

Taxation and Economic Growth

\section{Asa Johansson,}

Chistopher Heady,

Jens Matthias Arnold,

Bert Brys,

Laura Vartia 
Organisation de Coopération et de Développement Économiques

Organisation for Economic Co-operation and Development

03-Jul-2008

ECONOMICS DEPARTMENT

English - Or. English

TAXATION AND ECONOMIC GROWTH

ECONOMICS DEPARTMENT WORKING PAPER No. 620

By

Åsa Johansson, Christopher Heady, Jens Arnold, Bert Brys and Laura Vartia

All OECD Economics Department Working Papers are available on the OECD internet website at www.oecd.org/eco/working_papers

JT03248671 


\section{ABSTRACT/RESUMÉ}

\section{Taxation and Economic Growth}

This paper investigates the design of tax structures to promote economic growth. It suggests a "tax and growth" ranking of taxes, confirming results from earlier literature but providing a more detailed disaggregation of taxes. Corporate taxes are found to be most harmful for growth, followed by personal income taxes, and then consumption taxes. Recurrent taxes on immovable property appear to have the least impact. A revenue neutral growth-oriented tax reform would, therefore, be to shift part of the revenue base from income taxes to less distortive taxes such as recurrent taxes on immovable property or consumption. The paper breaks new ground by using data on industrial sectors and individual firms to show how redesigning taxation within each of the broad tax categories could in some cases ensure sizeable efficiency gains. For example, reduced rates of corporate tax for small firms do not seem to enhance growth, and high top marginal rates of personal income tax can reduce productivity growth by reducing entrepreneurial activity. While the paper focuses on how taxes affect growth, it recognises that practical tax reform requires a balance between the aims of efficiency, equity, simplicity and revenue raising.

JEL classification codes: $\mathrm{H} 23 ; \mathrm{H} 24 ; \mathrm{H} 25 ; \mathrm{O} 40 ; \mathrm{O} 43 ; \mathrm{C} 33$

Key words: taxation; tax design; tax policy; economic growth; productivity; investment

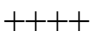

\section{Fiscalité et croissance économique}

Ce document examine la meilleure élaboration du système fiscal afin de promouvoir la croissance économique. Il suggère une classification des impôts selon le modèle "fiscalité et croissance ", venant étayer des résultats déjà connus dans des publications antérieures, mais proposant une ventilation plus détaillée des différents impôts. Il s'avère que les impôts sur les sociétés grèvent le plus la croissance, suivis par les impôts sur le revenu des personnes physiques, et ensuite les impôts sur la consommation. Les impôts sur l'immobilier semblent les moins nocifs. Une réforme fiscale sans incidence sur les impôts et orientée sur la croissance consisterait à transférer une partie de la base imposable des impôts sur le revenu sur des impôts moins générateurs de distorsion, comme les impôts récurrents sur l'immobilier ou ceux sur la consommation. Ce document est innovant dans la mesure où il utilise des données sur les secteurs industriels et les sociétés individuelles afin de démontrer que le fait d'élaborer une nouvelle fiscalité au sein d'une large catégorie d'impôts pourrait, dans certains cas, permettre un gain d'efficacité non négligeable. Par exemple, des taux réduits d'impôts sur les sociétés pour les petites entreprises ne semble pas augmenter favoriser la croissance; de même, des taux marginaux élevés d'impôts sur les revenus des personnes physiques peut réduire la courbe de la productivité en réduisant l'activité entrepreneuriale. Alors que ce document est centré sur la manière dont les impôts affectent la croissance, il reconnaît qu'une réforme fiscale pragmatique nécessite un équilibre entre efficience, équité, simplicité et levée d'impôts.

Codes JEL: $\mathrm{H} 23 ; \mathrm{H} 24 ; \mathrm{H} 25 ; \mathrm{O} 40 ; \mathrm{O} 43 ; \mathrm{C} 33$

Mots clé: imposition; conception fiscale; politique fiscale; croissance économique; productivité; investissement

Copyright OECD, 2008. All rights reserved.

Application for permission to reproduce or translate all, or part of, this material should be made to: Head of Publications Service, OECD, 2 rue André-Pascal, 75775 PARIS CEDEX 16, France. 


\section{TABLE OF CONTENTS}

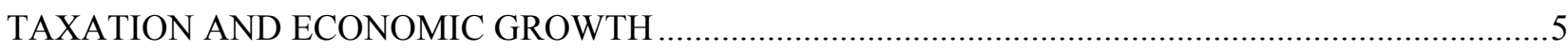

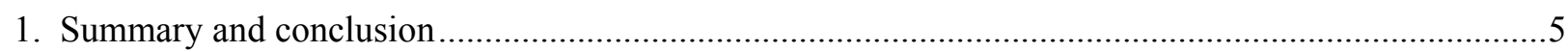

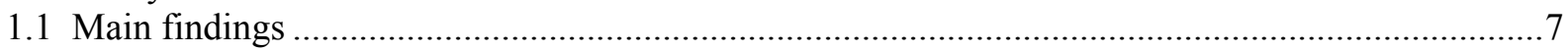

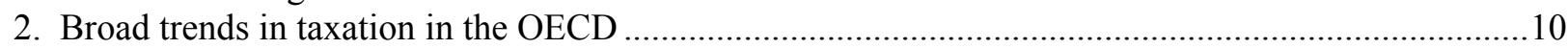

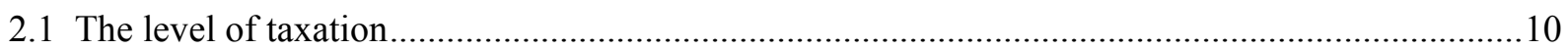

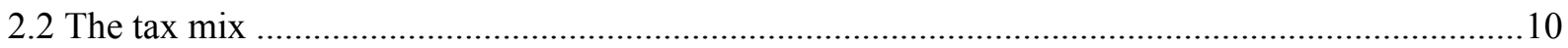

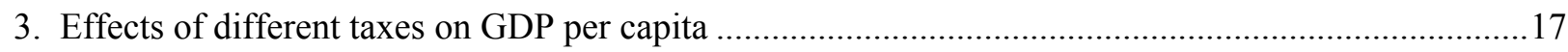

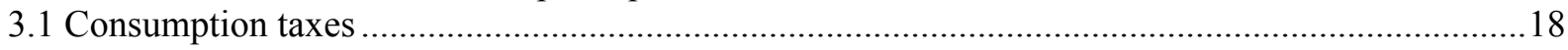

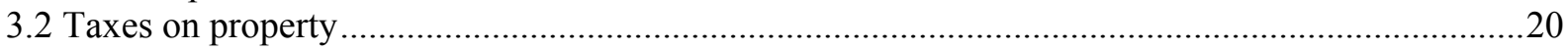

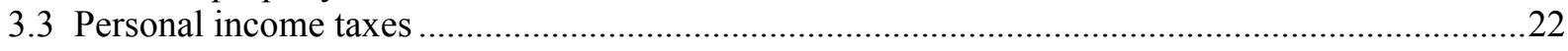

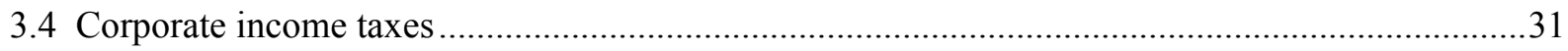

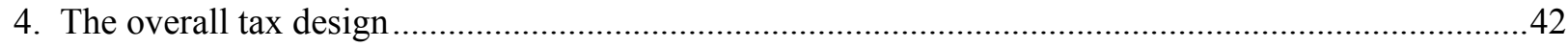

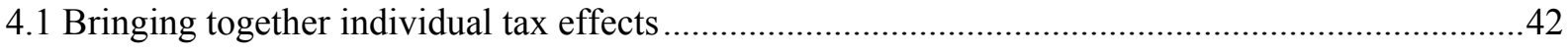

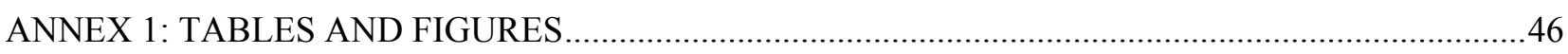

ANNEX 2: DESCRIPTION OF TAX INDICATORS........................................................................... 71

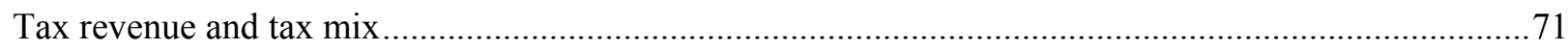

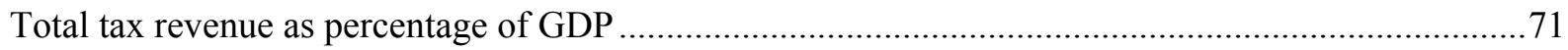

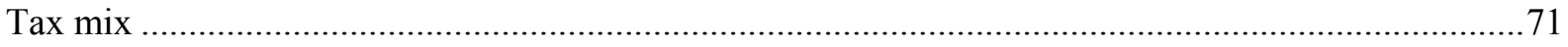

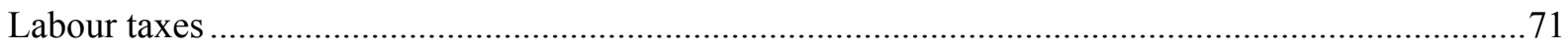

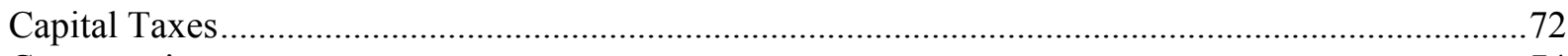

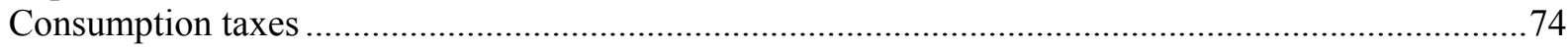

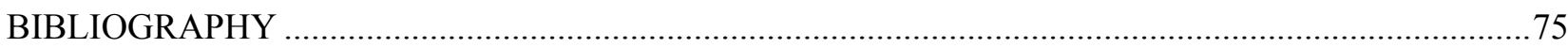

\section{Boxes}

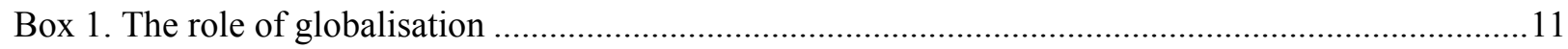

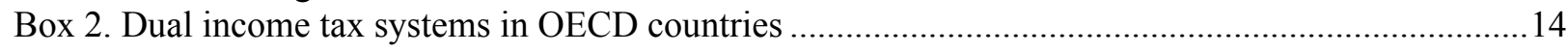

Box 3. Existing OECD evidence on the effects of personal income taxes ..............................................24

Box 4. Estimating the effect of labour taxes on total factor productivity (TFP) ....................................27

Box 5. Flat personal income tax reform experiences .............................................................................

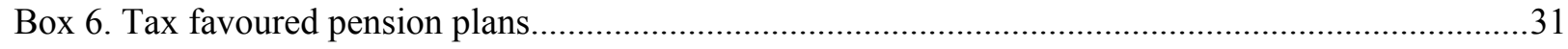

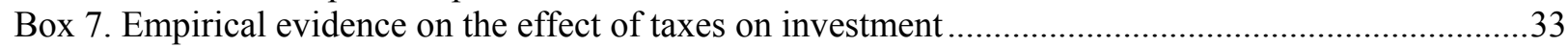

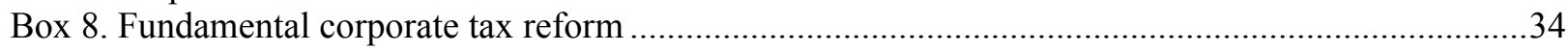

Box 9. Estimating the effect of corporate taxes and R\&D tax incentives on TFP ......................................35

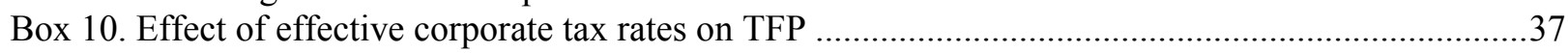

Box 11. Empirical findings on the aggregate effects of the tax structure on GDP ................................43 


\section{Tables}

1. Revenue shares of the major taxes in the OECD area

2. The evolution of standard value-added tax rates

3. Taxation of residential property (2002)

4. Taxes on capital income at the household level in selected OECD countries (2004/2005)

5. Standard and reduced (targeted) corporate income tax rates for small businesses (2005)

6. Estimated effects of labour taxes on TFP - industry-level

7. Estimated effects of corporate taxes on investment: firm-level

8. Estimated effects of corporate taxes on investment: industry-level

9. Estimated effects of corporate taxes on TFP: firm-level

10. Estimated effects of corporate taxes on TFP: industry-level

11. Estimated cross-country effects of the tax mis on long-run GDP per capita

\section{Figures}

1. Tax-to_GDP ratios in the OECD areas (1975-2006)

2. Tax structures in the OECD, 1985 and 2005 (selected countries/areas)

3. Revenues from environmentally-related taxes in per cent of GDP

4. The evolution of property taxdes (as a percentage of GDP)

5. Top statutory personal income tax rates on wage income

6. Average income tax for a single individual at average earnings

7. Statutory income tax progressivity for single individuals at average earnings

8. Tax wedge for a single individual at average earnings

9. Statutory corporate income tax rates

10. Overall statutory tax rates on dividend income (2000 and 2007)

11. Tax subsidies for one US\$ of research and development in OECD countries (2007)

12. Taxes affect the determinants of growth

13. C-efficiency for VAT (average 2002-2004)

14. Tax matrix 


\title{
TAXATION AND ECONOMIC GROWTH
}

\author{
By Åsa Johansson, Christopher Heady, Jens Arnold, Bert Brys and Laura Vartia ${ }^{1}$
}

\section{Summary and conclusion}

1. Tax systems are primarily aimed at financing public expenditures. Tax systems are also used to promote other objectives, such as equity, and to address social and economic concerns. They need to be set up to minimise taxpayers' compliance costs and government's administrative cost, while also discouraging tax avoidance and evasion. But taxes also affect the decisions of households to save, supply labour and invest in human capital, the decisions of firms to produce, create jobs, invest and innovate, as well as the choice of savings channels and assets by investors. What matters for these decisions is not only the level of taxes but also the way in which different tax instruments are designed and combined to generate revenues (what this paper will henceforth refer to as tax structures). The effects of tax levels and tax structures on agents' economic behaviour are likely to be reflected in overall living standards. Recognising this, over the past decades many OECD countries have undertaken structural reforms in their tax systems. Most of the personal income tax reforms have tried to create a fiscal environment that encourages saving, investment, entrepreneurship and provides increased work incentives. Likewise, most corporate tax reforms have been driven by the desire to promote competition and avoid tax-induced distortions. Almost all of these tax reforms can be characterised as involving rate cuts and base broadening in order to improve efficiency, while at the same time maintain tax revenues.

2. This paper focuses on the effects of changes in tax structures on GDP per capita and its main determinants. Focusing on tax structures rather than levels is desirable because cross-country differences in overall tax levels largely reflect societal choices as to the appropriate level of public spending, an issue that is beyond the scope of tax policy analysis. Conversely, investigating how tax structures could best be designed to promote economic growth is a key issue for tax policy making. Yet, in practice, it is hard to completely separate the analysis of the overall tax burden from that of tax structure: countries that have a relatively high level of taxes may also have a tax structure that differs from that of other countries, and the response of the economy to a change in the tax structure varies across countries, depending on their tax level. Even more importantly, fully disentangling the revenue raising function of the tax system from its other objectives, e.g. equity, environmental or public health matters is difficult. In order to make the assessment of the effects of the tax structure on economic performance manageable, these objectives are not dealt with in great detail in this study, except when there is a clear trade off between them and tax

1 Corresponding authors are Åsa Johansson (Email: Asa.Johansson@oecd.org) at the OECD Economics Department and Christopher Heady (Email: Christopher.Heady@oecd.org) at the OECD Centre for Tax Policy and Administration. This work has benefitted greatly from important contributions from Stefano Scarpetta. The authors would also like to thank Jørgen Elmeskov, Giuseppe Nicoletti, Jeffrey Owens, JeanLuc Schneider and Cyrille Schwellnus for their valuable comments and Ana Cebreiro-Gomez for helpful inputs as well as Irene Sinha for excellent editorial support. The views expressed in this paper are those of the authors and do not necessarily reflect those of the OECD or its member countries. 
reforms aimed at raising GDP per capita. Nevertheless, the ways in which governments use the tax system to achieve these other objectives have been extensively studied by the OECD (for instance, see OECD, $2005 \mathrm{c}$, on equity and OECD, 2006d, on the environment).

3. Most of the discussion on the link between changes in the tax structure and economic performance focuses on the effects on GDP levels. This paper, however, recognises that in practice it may be difficult to distinguish between effects on levels and growth rates. Indeed, any policy that raises the level of GDP will increase the growth rate of GDP because effects on GDP levels take time. Also, transitional growth may be long-lasting, and so it has not proved possible to distinguish effects on long-run growth from transitional growth effects, although some elements of the tax system are likely to have a bearing for long-run growth. For instance, it is possible that taxes that influence innovation activities and entrepreneurship may have persistent long-run growth effects, while taxes that influence investment also can have persistent effects on growth but these will fade out in the long-run. In contrast, taxes affecting labour supply will mainly influence GDP levels. In this spirit, this study looks at consequences of taxes for both GDP per capita levels and their transitional growth rates, with a large part of the empirical analysis devoted to assessing the effects of different forms of personal and corporate income taxation on total factor productivity growth.

4. In open economies the design of a national tax system will need to consider the design of tax systems in other countries, since countries are increasingly using their tax systems to improve their ability to compete in global markets. Globalisation may also increase the opportunities for tax avoidance and evasion especially as concerns mobile capital income tax bases. Therefore, the mobility of the tax base plays some part in the design of tax reforms at the national level, and increased international tax policy cooperation among countries may allow for efficiency gains in some areas (for a discussion on this see Box 1).

5. However, there are important issues that this study addresses only cursorily. First, optimal taxation, or how to minimise the excess burden of taxation, is an important topic that is largely outside the scope of this project, although some references are made to the main insights provided by research in this area. Likewise, tax incidence, or who bears the burden of a tax, is not explicitly addressed in this work, except when it has implications for the way the tax structure affects the determinants of growth.

6. Second, the transition costs of tax reform are not considered. These include not only the costs to the public administration but also the costs to businesses in adapting to policy changes. In some circumstances, it might also include the costs of 'grandfathering' some of the old tax provisions (or some other form of compensation) if taxpayers have made substantial investments based on the expectation that these provisions would be maintained. The existence of these costs implies that tax reform will only be attractive if it can be expected to produce offsetting gains in economic performance.

7. Against this background, the analysis in the paper is organised as follows. First, it reviews tax structures and general trends in taxes that are particularly relevant for growth. Second, drawing on theory, existing and new evidence, and the practical experience of member countries, it investigates how the structure of the tax system can have an impact on GDP per capita through its components, labour utilisation and labour productivity. Taking a bottom-up approach, the impact on performance of each of the main categories of taxes (consumption, property, personal and corporate taxation) is discussed and some conclusions are drawn concerning efficient tax design in each of these areas. Third, in the light of this discussion, the final section sketches possible reform avenues for moving towards an overall tax structure that may enhance aggregate economic performance, conditional on the specificities of each country. The proposed framework for describing the main channels through which tax structures affect GDP per capita could in the future be used to identify tax policy priorities in the context of the "Going for Growth" exercise. 


\subsection{Main findings}

\section{General tax trends}

- Despite cross-country differences in the tax structure, most OECD countries rely on three main sources of tax revenues: personal and corporate income taxes, social security contributions and taxes on goods and services. During the past three decades there has been a reduction in the share of tax revenues accounted for by personal income tax while the revenue shares of corporate income taxes and social security contributions have increased. The share of consumption taxes in total revenues has declined, with the mix of taxes on goods and services changing noticeably towards greater use of general consumption taxes (mainly VAT) and away from taxes on specific goods and services. The share of property taxes and environment-related taxes has been fairly constant over time.

- In many OECD countries a change towards flatter personal income tax schedules has occurred, with one of the most pronounced changes in personal income taxation being the reduction in the top statutory income tax rates. In contrast, average workers have not seen their taxes being cut to the same extent. A number of countries have introduced various in-work tax measures to encourage work incentives of marginal workers.

- The reduction in the personal income tax rates has been accompanied by cuts in the corporate income tax rate, partly financed by base broadening in many countries. Likewise, the overall top marginal rate on dividends has decreased mainly as a result of the reduction in the corporate income tax rate. Several countries have introduced tax incentives for investment in research and development.

\section{Broad policy options for reforming the overall tax mix}

8. The tax policy changes that are most likely to increase growth in any particular country will depend on its starting point, in terms of both its current tax system and the areas (such as employment, investment or productivity growth) in which its current economic performance is relatively poor. The discussed reforms should be seen as small tax changes rather than suggesting that shifting the revenue base entirely to one particular tax instrument provides more of a growth bonus since it is probable that there are diminishing growth returns to adjusting taxes.

9. The analysis in this paper suggests some general policy options that could be considered:

- The reviewed evidence and the empirical work suggests a "tax and growth ranking" with recurrent taxes on immovable property being the least distortive tax instrument in terms of reducing long-run GDP per capita, followed by consumption taxes (and other property taxes), personal income taxes and corporate income taxes.

- A revenue neutral growth-oriented tax reform would be to shift part of the revenue base from income taxes to less distortive taxes. Taxes on residential property are likely to be best for growth. However, the scope for switching revenue to recurrent taxes on immovable property is limited in most countries both because these taxes are currently levied by sub-national governments and because these taxes are particularly unpopular. Hence, despite the advantages of drawing on an immovable tax base in a period of globalisation, few countries manage to raise substantial revenues from property taxes, with returns on housing generally taxed more lightly than returns on other assets. 
- In practical policy terms, a greater revenue shift could probably be achieved into consumption taxes. However, with consumption taxes being less progressive than personal income taxes, or even regressive, a shift in the tax structure from personal income to consumption taxes would reduce progressivity. Similarly, shifting from corporate to consumption taxation would increase share prices (by increasing the after-tax present value of the firm) and wealth inequality as well as increasing income inequality by lowering capital income taxation. Such tax shifts therefore imply a non-trivial trade-off between tax policies that enhance GDP per capita and equity, which is likely to be evaluated differently across OECD countries.

- However, changing the balance between different tax sources should not been seen as a substitute for improving the design of individual taxes. Indeed, the reform of individual taxes can complement a revenue shift. For example, broadening the base of consumption taxes is a better way of increasing their revenues than rate increases, because a broad base improves efficiency while a high rate encourages the growth of the shadow economy. More generally, most taxes would benefit from a combination of base broadening and rate reduction.

- Looking within income taxes, relying less on corporate income relative to personal income taxes could increase efficiency. However, lowering the corporate tax rate substantially below the top personal income tax rate can jeopardize the integrity of the tax system as high-income individuals will attempt to shelter their savings within corporations.

- Focusing on personal income taxation, there is also evidence that flattening the tax schedule could be beneficial for GDP per capita, notably by favouring entrepreneurship. Once again, this implies a trade-off between growth and equity.

\section{Possible avenues for tax reforms to enhance the performance of the various drivers of GDP}

Labour utilisation

10. Reforms of labour income taxation will generally have to differ depending on whether the aim is to raise participation or hours worked. Reducing average labour taxes could be desirable for raising participation, while lowering marginal rates may be preferable for increasing hours worked. Any such reform should, however, take into account joint effects with existing benefits, which could affect the effective average and marginal tax rates, particularly for low-skilled workers or second-earners. Also, reductions in the marginal tax rate will lead to greater income inequality. Moreover, the effects of changes in labour taxes on employment are also likely to be dependent on labour market institutions, such as wagesetting mechanisms and minimum wages, which affect the pass through of taxes on to labour cost.

11. There may also be gains, both in the quantity and the quality of labour supply, from reducing the progressivity of the personal income tax schedule. Estimates in this study point to adverse effects of highly progressive income tax schedules on GDP per capita through both lower labour utilisation and lower productivity (see below) partly reflecting lesser incentives to invest in higher education. Again, this implies a potential trade-off between growth-enhancing tax policies and distributional concerns. However, there may be win-win labour tax reforms in this area. For example, "in-work benefits" increase the income of low-income households, thus reducing inequality, and may also improve efficiency if the gain in labour force participation outweighs the adverse incentives on hours worked by job-holders (as benefits are withdrawn) and on human capital formation (as the returns from up-skilling are reduced) as well as the distortionary costs of the tax increases that are needed to finance the in-work benefits. 
Investment

12. Reducing corporate tax rates and removing special tax relief can enhance investment in various ways.

- Especially, if the primary aim is to reduce distortions that hold back the level of domestic investment and to attract foreign direct investment, reducing the corporate tax rate may be preferable to reducing personal income taxes on dividends and capital gains.

- Evidence in this study suggests that favourable tax treatment of investment in small firms may be ineffective in raising overall investment.

- Lowering the corporate tax rate and removing differential tax treatment may also improve the quality of investment by reducing possible tax-induced distortions in the choice of assets.

- Providing greater certainty and predictability in the application of corporate income taxes may lead to higher investment, which in turn, could enhance growth performance.

Productivity

13. There are several ways in which tax policy can influence productivity:

- One option is to reduce the top marginal statutory rate on personal income since it has an impact on productivity via entrepreneurship by affecting risk taking by individuals. While empirical research has pointed to conflicting ways in which entrepreneurship could be affected, in this study a reduction in the top marginal tax rate is found to raise productivity in industries with potentially high rates of enterprise creation. Thus reducing top marginal tax rates may help to enhance economy-wide productivity in OECD countries with a large share of such industries, though the trade off with equity objectives needs to be kept in mind. It is also possible that cutting top marginal tax rates could increase economy-wide productivity through composition effects, by increasing the share of industries with high rates of enterprise creation.

- A second option is to reform corporate taxes, as they influence productivity in several ways. Evidence in this study suggests that lowering statutory corporate tax rates can lead to particularly large productivity gains in firms that are dynamic and profitable, i.e. those that can make the largest contribution to GDP growth. It also appears that corporate taxes adversely influence productivity in all firms except in young and small firms since these firms are often not very profitable. One possible implication is that tax exemptions or reduced statutory corporate tax rates for small firms might be much less effective in raising productivity than a generalised reduction in the overall statutory corporate tax rate. This reduction could be financed by scaling down exemptions granted on firm size as they may only waste resources without any substantial positive growth effects.

- A widely-used policy avenue to improve productivity is to stimulate private-sector innovative activity by giving tax incentives to R\&D expenditure. This study finds that the effect of these tax incentives on productivity appears to be relatively modest, although it is larger for industries that are structurally more R\&D intensive. Nonetheless, tax incentives have been found to have a stronger effect on R\&D expenditure than direct funding.

- Lower corporate and labour taxes may also encourage inbound foreign direct investment, which has been found to increase productivity of resident firms. In addition, multinational enterprises 
are attracted by tax systems that are stable and predictable, and which are administered in an efficient and transparent manner.

Again, it needs to be emphasised that policymakers will need to examine very carefully the trade-off between these growth-enhancing proposals and other objectives of tax systems - particularly equity.

\section{Broad trends in taxation in the OECD}

14. The level and mix of taxation vary markedly across OECD countries but there have been a number of common trends. Many countries have cut personal and corporate tax rates while broadening the tax base and increasing social security contributions. Meanwhile, there has been increased use of ValueAdded Taxes (VAT) and a general trend to higher VAT rates. The data presented in this section and throughout the paper refer to taxes levied by all levels of government.

\subsection{The level of taxation}

15. Between 1975 and 2006, there has been a persistent and largely unbroken upward trend in the ratio of tax to GDP across the OECD area increasing on average in the OECD by over six percentage points of GDP (Figure 1, see Annex 1 for Tables and Figures and Annex 2 for a description of the tax indicators), followed by some more recent signs of stabilisation in the tax revenue in the OECD as a whole. Several countries deviate from this trend. Iceland, Italy, Portugal and Spain all increased their tax to GDP ratios by more than ten percentage points over the period (although all starting from lower than average tax levels), while the increase for the United States was less than three percentage points and the Netherlands experienced a fall in the ratio of over one percentage point. In addition, the Czech Republic, Hungary and the Slovak Republic have reduced their ratios since joining the OECD. Measures of total tax to GDP ratios are routinely used for international comparisons of overall tax burdens, but these measures can be influenced by measurement issues. For example, in some countries transfers to households (such as benefits) are taxed in the same way as earnings, in others they are taxed at reduced rates, consequently affecting the measure of the tax to GDP ratio. ${ }^{2}$ Despite these conceptual and statistical problems, it is useful for policy analysis to consider the level and structure of taxation distinctly.

[Figure 1. Tax-to-GDP ratios in the OECD area, 1975-2006]

\subsection{The tax mix}

16. Despite some significant differences in the distribution of the tax burden between tax instruments, most OECD countries extract the bulk of revenue from three main sources: income taxes, taxes on goods and services, and social security contributions (other payroll taxes are zero or very small in most countries). The share of total tax revenue accounted for by these three main tax instruments has evolved over time (see Table 1 for the unweighted OECD averages). Some of these changes in the tax mix are endogenous while others are policy induced. Globalisation and the increased openness of economies may also be one factor driving the recent trends in taxation in OECD countries (Box 1). The main patterns for the OECD unweighted average over the last thirty years can be summarised as follows, although there are significant variations across countries in both the shares of individual taxes and the trends (Figure 2):

2 Social expenditure to GDP ratios are also influenced by the tax system because most countries have significant taxes on benefits. Adema and Ladaique (2005) found that adjusting gross social spending for the impact of direct taxation cross-country divergences in aggregate social spending are much smaller than implied by the raw numbers. The implication is that a similar relation would hold in the area of taxation, with raw numbers of tax burdens exaggerating cross-country differences. 
- There has been a reduction in the share of tax revenue accounted for by personal income tax, although the share has been fairly constant in Austria, Greece, Italy and the United Kingdom. In France and Iceland, the personal income tax revenue share has increased considerably.

- There has been a continuously growing share of social security contributions, which by 2005 accounted for $26 \%$ of total tax revenues, apart from France, Italy, the Netherlands and Spain where the share has decreased.

- The share of the corporate income tax in total tax revenues has increased in the majority of the OECD countries but not in the large OECD countries (France, Germany, Italy, Japan and the United Kingdom), except in the United States where the revenues have increased since 2005.

- The share of taxes on consumption (general consumption taxes plus specific consumption taxes) has declined gradually, but the mix of taxes on goods and services has changed markedly towards the greater use of general consumption taxes, particularly VAT. However, in Belgium, Denmark, Italy, Norway and the United States, the share of general consumption taxes remained rather constant while it decreased in Austria, France, Iceland and Turkey.

- The share of property taxes (on immovable property, net wealth, inheritances and legal transactions) has been approximately constant but not in France, Ireland, Korea, Luxembourg and Spain where the share has increased by more than 2.5 percentage points since 1980 and in New Zealand where it decreased more than 3 percentage points.

\section{Box 1. The role of globalisation}

Globalisation - the increased openness of economies to trade and investment combined with reduced transport costs and improved communications - has several effects that need to be taken into account in formulating tax policy:

Taxes can affect the costs of producing goods and services, and so change the relative international competitiveness of some sectors, prompting structural changes.

Tourism and cross-border shopping mean that even VAT and sales taxes, which do not normally apply to exports, can influence the demand of foreign residents for domestically produced goods and services.

Personal income taxes can influence workers, particularly those who are highly paid, in the choice of the country in which they work.

Corporate income taxes can influence the choice of location of factories and offices. The tax system is only one factor among many in improving countries' competitiveness otherwise there would have been a large outflow of capital and activities from high to low tax countries, but there is evidence that location decisions are becoming more sensitive to tax.

These factors mean that individual countries are likely to make different tax policy choices from those they would have made in the past, when there was less mobility. Also, as mobility depends on relative tax rates and is most likely to take place between nearby countries, it also means that groups of countries (such as the European Union) may be differently affected when they co-ordinate tax policy changes than would their individual member countries acting alone.

It is generally assumed that choices related to corporate taxation are most affected by globalisation because of the ease with which multinational enterprises can move the location of at least some of their activities. However, highly skilled workers are also becoming more mobile and some countries are taking this into account in designing their personal tax systems. In contrast, the taxation of lower-skilled workers and of consumption is seen as being less affected by globalisation because these tax bases are less mobile. Finally, the taxation of immovable property is seen as the least affected by globalisation.

The effects of this general ranking can be seen in the discussion of taxation trends in this section of the paper, with tax rates falling most for the more mobile tax bases. The ranking can also be expected to be a major factor driving the empirical results reported in this paper, as countries that ignore the pressures of globalisation may be expected to grow more slowly. But, a shift in the tax structure from mobile income taxes to less mobile taxes, such as consumption taxes, would reduce progressivity since consumption taxes are in general less progressive than income taxes. Therefore, such tax shifts imply a trade-off between growth enhancing tax reforms and equity. 
[Table 1. Revenue shares of the major taxes in the OECD area]

\section{[Figure 2. Tax structures in the OECD, 1985 and 2005 (selected countries/areas)]}

17. The remainder of this section briefly reviews the most important changes to consumption taxes, property taxes, personal income taxes and corporate income taxes in the past thirty years.

\section{Consumption taxes}

18. As shown above, the main changes to consumption taxes have been the decline in the revenue share of specific consumption taxes (such as the excise duties on alcohol, tobacco and vehicle fuels) and the large rise in revenues from general consumption taxes. The main factor behind the growth of general consumption tax revenues has been the spread of VAT - the United States is now the only OECD country that does not use VAT - and the gradual increase in the rates applied in many countries except in Canada, the Czech Republic, France, Hungary, Ireland and the Slovak Republic (Table 2).

19. There has also been growing interest in the use of environmentally-related taxes, with several countries introducing new taxes to deal with specific environmental problems. However, as shown in Figure 3, there has not been a general upward trend in their revenues as a proportion of GDP. Excise duties on motor fuels are the largest single source of environmentally-related tax revenue.

[Table 2. The evolution of standard value-added tax rates]

\section{[Figure 3. Revenues from environmentally-related taxes in per cent of GDP]}

\section{Property taxes}

20. Despite their general low revenue shares, property taxes remain an important source of revenue in some OECD countries, with the United Kingdom, Korea, the United States and Canada obtaining at least $10 \%$ of tax revenue from this source in 2005 . This group of taxes are diverse in both their design and their effects, as they include recurrent taxes on immovable property (paid by both households and businesses), taxes on net wealth (paid by both households and corporations), taxes on gifts and inheritance and taxes on financial and capital transactions. The evolution of the OECD average revenues from each of these taxes is illustrated in Figure 4. This shows that recurrent taxes on immovable property - mainly levied at the sub-national level - account for approximately half of total property taxes, while taxes on transactions account for about half of the rest. There are no strong trends in the revenues from any of these taxes as a share of GDP despite short-term variations. As a percentage of GDP, the recurrent taxes on immovable property have increased by 0.5 percentage points or more only in France, Italy, Portugal, Spain and Sweden and decreased by more than 0.5 percentage points in the United Kingdom. The taxes on financial and capital transactions, in percent of GDP, have increased by more than 0.4 percentage points in Belgium, Greece, Ireland, the Netherlands, Spain and the United Kingdom while they decreased by more than 0.4 percentage points only in Japan.

[Figure 4. The evolution of property taxes (as a percentage of GDP)]

21. Owner-occupied housing is taxed favourably in many countries, as can be seen from Table 3 . Imputed rental income is not taxed under the income tax (except in Belgium, the Netherlands, Norway and 
Sweden), although this should be seen in the context of most countries levying property taxes. At the same time, mortgage interest payments can be deducted from the personal income tax base in many countries, but not in Canada, Germany, France (they became partly deductible in 2007) and the United Kingdom. Some countries, like Belgium and Spain, even allow for a deduction of the principal repayments. Moreover, realised capital gains on owner-occupied houses are often not subject to capital gains tax, though the value of the house is subject to inheritance tax in most countries, except Canada and Sweden. Moreover, some countries levy a high transaction tax on the purchase of houses.

[Table 3. Taxation of residential property, 2002]

\section{Personal income taxes}

22. One of the most marked changes in taxation over the past 25 years has been the steep decline in the top rates of personal income tax in OECD countries (Figure 5). The OECD unweighted average has fallen from $67 \%$ in 1981 to $49 \%$ in 1994 and $43 \%$ in $2006 .{ }^{3}$ The largest reductions are observed in Japan (-43 percentage points), Portugal (-42.4 percentage points), the United States ( -34 percentage points) and Sweden (-31 percentage points). However, in general, this has not been matched by a reduction in the average income tax levied on the labour incomes of average production workers (Figure 6), where the OECD unweighted average has fallen by less than five percentage points from slightly below $19 \%$ in 1985 to slightly above $14 \%$ in 2004 . This difference has partly been due to the fact that marginal rates at lower income levels have not been reduced so much and partly due to the fact that most countries have not increased tax thresholds in line with the increase in average earnings. The largest reductions are observed in Ireland (-16.2 percentage points), Sweden (-11.6 percentage points) and Denmark (-9.4 percentage points). The average income tax has decreased by more than 7 percentage points also in New Zealand, Turkey and Luxembourg. Since 1985, the average income tax has strongly increased in Iceland $(+11$ percentage points) and France ( +5.7 percentage points). Despite the strong reduction in the top personal income tax rates in Japan, Portugal and the United States, the average income tax rate has decreased (comparing the values in 2004 with 1985) only by 3 percentage points in Japan, 1.3 percentage points in Portugal and 5.3 percentage points in the United States.

\section{[Figure 5. Top statutory personal income tax rates on wage income]}

\section{[Figure 6. Average income tax for a single individual at average earnings]}

23. The concentration of personal income tax cuts at the top of the income distribution has been reflected in a reduction of the progressivity of the personal income tax in most OECD countries. ${ }^{4}$ The progressivity measure in Figure 7, which compares marginal and average tax wedges for single workers, focuses on taxes at the average wage level. Since 1995, the largest reductions (more than 8 percentage points) are observed in Canada, Iceland, Ireland, France and the Netherlands. This measure does not take into account the impact of tax changes on lower and higher-incomes. In fact in recent years, the tax system has become slightly more progressive when the average tax burden on low and high-income earners is compared. This is mainly the result of the introduction of in-work tax credits in many countries (e.g.

3 If the average is only applied to the countries for which data were available in 1981, the 1994 percentage becomes 50 and the 2006 percentage becomes 46 .

The measure of progressivity used is the difference between the marginal and average personal income tax rates, divided by one minus the average personal income tax rate, for an average single production worker. A higher number indicates higher progressivity at the earnings of an average worker. 
Finland, France, the United Kingdom and the United States), which have reduced the tax burden on lowincome earners more than the reduction in the tax burden on high-incomes caused by the reduction in top statutory income tax rates. Another recent trend in personal income taxation is that some OECD countries, mostly Scandinavian countries, have introduced a dual tax system which taxes personal capital income at low and proportional rate while labour income continues to be taxed at high and progressive rates (Box 2). Several other countries have moved away from comprehensive towards 'semi-dual' personal income taxes.

\section{Box 2. Dual income tax systems in OECD countries}

Finland, Norway, Sweden and to a lesser extent Denmark introduced a dual income tax system in the early 1990s. The purest dual income tax system has been established in Norway. The main characteristics of the Norwegian system in 2005 were:

A flat personal income tax rate of $28 \%$ on net income, which includes wage, pension and capital income less tax deductions. The same rate is used for corporate income. This implies:

a symmetrical treatment of all capital income with no double taxation of dividends and capital gains on shares and full deductibility of all interest expenditures. At the same time, double taxation of distributed profits was prevented through a full imputation system. Shareholders were permitted a tax credit against the personal income tax on dividends for the corporate tax that could be imputed to the dividends they have received.

a broad tax base, aiming to bring taxable income in line with true economic income and a reduction of the number and the value of tax allowances, as all remaining allowances are deductible only at the flat $28 \%$ tax rate.

- Progressive taxation of wage and pension income in addition to the flat rate, by means of surtax on gross income from wages and pensions above a certain threshold level. The highest surtax rate on wages and pensions was $13 \%$ when the tax reform was implemented in 1992; it increased to $19.5 \%$ in 2000 and it decreased to $15.5 \%$ in 2005.

In order to ensure an equal tax treatment of wage earners and the self-employed, the dual income tax system splits the income of the self-employed into a labour income component as a reward for work effort and a capital income component, which is the return to the savings invested in the proprietorship. The part considered as labour income is taxed according to the progressive rate schedule, while the part considered as capital income is taxed at the flat rate. This so-called split-model imputes a return to the capital invested and categorizes the residual income as labour income (Sørensen, 1998).

In general, the main problems with the dual income tax system are twofold. First, dividends and capital gains on foreign shares are often taxed more heavily than dividends and capital gains on shares in domestic companies (for instance because the imputation credit is provided only to domestic shares). A second problem of dual income tax systems arises because of the large difference in top marginal tax rates on labour and capital income. This difference provided taxpayers with a tax-induced incentive to have their income characterised as capital income rather than as labour income, for instance by incorporating themselves. These income shifting problems are observed in most countries where the tax burden on capital income deviates from the tax burden on labour income. The fact that social security contributions are often levied only on labour income just strengthens the income shifting.

In practice, a majority of OECD countries may be characterized as having 'semi-dual' income tax systems, which are defined as tax systems that use different nominal tax rates on different types of income, typically by taxing some forms of capital income at low and often flat rates and remaining forms of income at higher and progressive rates. An example is the Box system in the Netherlands, which was introduced in 2001 . The tax reform reduced the tax rates and broadened the base, replaced tax allowances by tax credits, replaced the wealth tax and the taxation of personal capital income with the taxation of an imputed income from capital. Instead of a tax on the actual return on saving income, a $30 \%$ proportional tax rate is applied on a notional return of $4 \%$ on the net value of the assets owned by the shareholder. This presumptive capital income tax, which ensures that all forms of personal capital income are taxed equally, is therefore equivalent to a tax on net wealth of $1.2 \%$. Progressivity is obtained through a basic tax-free allowance.

Source: OECD (2006b): "Fundamental Reform of Personal Income Tax". 
[Figure 7. Statutory income progressivity for single individuals at average earnings]

\section{Social security contributions}

24. All OECD countries except Australia and New Zealand levy compulsory social security contributions on labour income, in addition to personal income tax. As noted above, there has been a general upward trend in these contributions. This has resulted in a smaller reduction in the overall taxation of labour income than would be observed by considering personal income taxes alone. Figure 8 shows the evolution of the tax wedge (incorporating both social security contributions and personal income tax) ${ }^{5}$ applied to the earnings of the average production worker. The OECD unweighted average has fallen by less than one percentage point from 1985 to 2004, much less than the fall in personal income tax of about $5 \%$, noted above. Even though the OECD average has hardly changed over this period, the tax wedge for the average production worker declined by more than 5 percentage points in Denmark, Ireland, Luxembourg, New Zealand, the Netherlands and the United Kingdom. Meanwhile, the tax wedge increased by more than 5 percentage points in Australia, Canada, Germany, Iceland, Japan and Turkey.

\section{[Figure 8: Tax Wedge for single individual at average earnings]}

25. A few OECD countries (e.g. Australia, Austria and Canada) levy payroll taxes (also included in the tax wedge), which are similar to employers' social security contributions but do not give an entitlement to social benefits. The amounts of revenue involved are generally small and do not show any particular time trend.

\section{Taxes on corporate income}

26. The reduction in personal income taxes has been accompanied by cuts in corporate tax rates. Since 1994, the largest rate reductions have been implemented in Hungary (-16 percentage points), the Czech Republic (-18 percentage points), Italy ( -20 percentage points), Poland and the Slovak Republic (-21 percentage points), Turkey (-26 percentage points) and Ireland ( -27.5 percentage points). The corporate tax rate has increased only in France and Finland $(+1.1$ and +1 percentage point respectively) (Figure 9). In the OECD area, the unweighted average corporate tax rate has dropped from $47 \%$ in 1981 to $40 \%$ in 1994 and $27.6 \%$ in 2007 . The corporate tax rate reductions have been partly financed by corporate tax base broadening measures in many countries -- for instance through the implementation of less generous tax depreciation allowances, the reduction in the use of targeted tax provisions and stricter corporate tax enforcement policies enacted by OECD countries. ${ }^{6}$ As the rate cuts were not fully financed by reductions in depreciation allowances, effective tax rates also fell although, as noted earlier, corporate tax revenues have tended to increase reflecting, inter alia, rising corporate profits. This increase in corporate profits is partly a result of increased incentives for businesses to incorporate, especially in the European Union (De Mooij and Nicodème, 2007). The revenue effects of lower corporate tax rates will therefore partly show up in lower personal income tax revenues rather than lower corporate income tax revenues (OECD, 2007b).

5 The tax wedge measures the amount of personal income tax, employees' and employers' social security contribution and payroll taxes less cash benefits as a proportion of labour costs, defined as the wage plus employers' social security contributions and payroll taxes.

Some OECD countries (e.g. the United States and Mexico) have implemented an alternative minimum tax, which is a tax that eliminates many tax reliefs and so creates a tax liability for an individual or corporation with high income who would otherwise pay little or no tax. 


\section{[Figure 9. Statutory corporate income tax rates]}

27. The rate of taxation on dividends combines features of both the personal and corporate tax systems. It has been of particular interest in recent years, given the policy focus on the relevant advantages, disadvantages and methods of integrating corporate and personal level taxation of distributed income. Figure 10 reports the top marginal tax rates on the distribution of domestic source profits to a resident individual shareholder, taking account of the fact that profits are usually taxed both at the corporate level and again when they are distributed as dividends (although double taxation may be reduced by introducing imputation systems, tax credits or reduced tax rates on dividends).

28. Many European countries have moved away from full imputation systems to systems where dividends are taxed at a lower rate at the personal level. ${ }^{7}$ Germany introduced the so-called half-income system in 2002 , whereby $50 \%$ of dividends are taxed as personal income. ${ }^{8}$ Several other countries have introduced or are introducing similar partial inclusion systems where some proportion of dividends are taxed as personal income, e.g. Finland, France, Italy, Portugal and Turkey.

[Figure 10. Overall statutory rates on dividend income (2000 and 2007)]

29. On average, the top marginal tax rate on dividends in OECD countries was reduced by more than 7 percentage points between 2000 and 2007 to $43 \%$ (Figure 10). The largest part of this reduction is attributable to the reduction in the corporate income tax rate. The part of the tax that is paid as corporate income tax has decreased by more than 5 percentage points to $27.6 \%$ on average in the OECD. A smaller part of the reduction in the statutory tax burden on dividends is due to the decrease in personal income tax rates. ${ }^{9}$ Since 2000, the top marginal tax rate on dividends has increased only in Finland and Norway (as a result of the introduction of the partial inclusion system in Finland and the allowance for shareholder equity tax system in Norway) and in Korea.

30. In many countries, interest payments are taxed at the household level at higher rates than dividends in order to (partly) offset the corporate tax rate that has been levied on equity income while interest payments are deductable from the corporate tax base (Table 4). Also, capital gains are taxed at the household level differently from dividends in many OECD countries (see Section 3 below).

\section{[Table 4. Taxes on capital income taxation at the household level in selected OECD countries $(2004 / 2005)]$}

31. In the OECD, ten countries levy a reduced corporate income tax rate on the profits of small businesses that are below a certain ceiling (Table 5). In order to benefit from the reduced rate, other conditions have to be fulfilled as well. In some countries, small businesses benefit from other special corporate tax provisions, such as expensing of investments.

\section{[Table 5. Standard and reduced (targeted) corporate income tax rate for small businesses} (2005)]

7 Under a full imputation system, dividends paid by a resident firm out of income that has already borne company tax can be passed on to resident shareholders by giving imputation credits for company tax paid

8 This was abolished in Germany as part of the 2008 corporate tax reform.

9 The reduction of the effective tax rate was 10.8 percentage points in the United States, due to the recent introduction of a reduced tax rate on dividends at the personal level. 
32. A growing feature of corporate tax systems is the use of tax credits or special deductions for research and development (R\&D) expenditures. These are now available in more than half the OECD countries. Figure 11 reports the value of the tax subsidies for $R \& D$ that is provided by these measures. ${ }^{10}$ Norway, the Czech Republic, Portugal, Mexico and Spain are the countries that provide the most generous R\&D tax treatment. Some countries provide more generous tax subsidies for R\&D in small- and mediumsized enterprises than for large companies. This is especially the case in Canada and the Netherlands.

[Figure 11. Tax subsidies for one US\$ of research and development in OECD countries 2007)]

\section{Effects of different taxes on GDP per capita}

33. As discussed in the previous section, there are large differences in both tax levels and tax structures across OECD countries. Economic theory suggests that these differences may play a role in explaining differences in economic performance. The structure of the tax system can have an impact on GDP per capita by affecting the amount of hours worked in the economy (labour utilisation), and the amount of output that is produced per hour (labour productivity) or both. However, it is generally difficult to assess the overall effect of a tax reform on output performance for several reasons. First, changes in any single tax may simultaneously affect several determinants of GDP per capita. For instance, a reduction in the average labour tax may increase employment (ultimately affecting labour utilisation) but at the same time it increases the opportunity cost to undertake higher education and, assuming progressivity is not influenced, therefore reduces incentives to invest in education (ultimately affecting labour productivity). Second, tax reforms typically involve changes in several kinds of tax instruments at once, with complementary or offsetting effects on the determinants of GDP per capita. Third, the effects of changes in taxation often depend on the design of other policies and institutions. Thus, the adverse effect of labour taxes on employment is typically dependent on wage-setting institutions, including minimum wages, which affect among other things the pass through of taxes on to labour cost.

34. This section focuses on the influence that the design of the different taxes - consumption, property, personal and corporate taxes - can have for GDP per capita levels and growth rates. The described effects are partial, since the effect of one tax on GDP per capita and its determinants are assessed holding all other taxes constant. Section 4 explores the combined effects on GDP per capita of changes in several tax instruments as well as their joint effects with policies and institutions that are country-specific. Throughout the analysis, a bottom-up approach looking at the influence of one tax on the various determinants of GDP will be used (as sketched in Figure 12). Two important limitations with this approach are that an empirical comparison of the magnitudes of the different tax effects on economic performance is not possible and that not all potential joint effects between different taxes or between taxes and institutions may be fully explored.

\section{[Figure 12. Taxes affect the determinants of growth]}

35. An alternative to this "bottom-up" analysis would be to develop simulation or general equilibrium models. These models have the advantage that they often have a detailed description of the magnitude of the effect of the various kinds of taxes on different categories of taxpayers and account for the inter-linkages between different markets. But most often these models are designed on a country

10 Figure 11 shows a negative value for tax subsidies in some countries. This is because the baseline of the definition (which gives a value of zero for the measure) represents the immediate deductibility of the capital costs for R\&D from the corporate tax base (immediate expensing), which is more generous than the typical tax treatment given to capital costs for other activities. Therefore, a negative value in the figure does not imply that the tax treatment of R\&D is less favourable than for other forms of investment. 
specific basis and the parameters of the model are calibrated to replicate the dynamics of a specific country. Therefore, these models are useful for assessing the effects of tax reforms in individual countries, but they are not practical for cross-country analysis since it is difficult to develop and empirically calibrate a model that takes into account the structure and dynamics of a large number of countries. In addition, the dynamics of these models can be difficult to interpret and often only very long-term relationship can be discussed.

\subsection{Consumption taxes}

36. Consumption taxes can be categorised as either general consumption taxes, typically VAT or sales tax (which are applied on a broad range of goods and services), or specific consumption taxes, such as excises and import duties, which are applied on a limited number of goods and services. In general, consumption taxes and particularly VAT are often thought to have a less adverse influence on the decisions of households and firms and thus on GDP per capita than income taxes. However, these advantages have to be balanced against equity concerns that arise from their lack of progressivity.

\section{Consumption taxes are neutral to saving...}

37. Since consumption taxes apply the same tax rate on current and future consumption (provided that tax rates are constant over time) they do not influence the rate of return on savings and individual's savings choices as income taxes do. Hence, consumption taxation is often seen as favouring private savings relative to income taxation. However, the empirical evidence on the sensitivity of private savings to aftertax interest rate changes is inconclusive: some studies found sizeable effects of interest rates on savings while other studies found no effects at all (e.g. Hall, 1988; Summers 1982). In an open economy with mobile capital, any changes in private savings are likely to over-state the resulting change in the capital stock, and hence GDP. Nonetheless, increased private savings can be expected to increase future net national income, provided that budgetary policy remains stable and allows the savings to flow into (possibly foreign) income-earning investments.

\section{...but they may affect employment and hours of work in the same way as income taxation.}

38. Because they lower the purchasing power of real after-tax wages, consumption taxes may curb labour supply in much the same way as a proportional income tax. Consumption taxes can also reduce labour demand in the short-term if they add to wages and labour cost. ${ }^{11}$ The extent and persistence of this effect depends on labour market settings (e.g. bargaining systems). The empirical evidence of the impact of consumption taxes on labour supply and employment is sparse. Most empirical studies that assess the effect of taxation on employment exclude consumption taxes from the relevant wedge (e.g. Pissarides, 1998, Bassanini and Duval, 2006). However, some recent studies that include the consumption tax in the overall labour tax wedge find that a rise in this wedge reduces market work, though no separate effect of consumption taxes on employment is estimated (e.g. Nickell, 2004).

\section{Differentiated consumption taxes can encourage work...}

39. The pattern of consumption taxes can also affect labour supply. Relatively high consumption taxes on goods complementary to leisure (such as golf clubs) encourage work, as can relatively low consumption taxes (or even subsidies) on goods complementary to work (such as child care). Corlett and Hague (1953) show that the benefits of (sufficiently small) non-uniformities in taxation outweigh the harm of distorting consumer choice. It can be shown (Heady, 1987) that this is a generalisation of the famous

11 Short-term inflationary effects may influence wages and labour cost, but what matters for long-run employment is the total tax wedge and what matters for long-term inflation is monetary policy. 
'inverse elasticity rule' derived by Ramsey (1927) that can also be used to justify (aside from public health considerations) the high taxes that are often applied to alcohol and tobacco products. In practice, it is difficult to clearly identify those goods for which the efficiency gain of taxation at a special rate outweighs the additional administrative and compliance costs. So, as argued by Ebrill et al. (2001), the few goods for which it can be justified are probably best dealt with by special excise taxes or (in the case of child care) subsidies rather than by a multi-rate VAT or sales tax system.

....and can yield environmental benefits...

40. Specific consumption taxes that penalise the production and consumption of "bads" can improve environmental outcomes while generating revenues that can be used to offset other taxes on, for example, labour. Examples are excise duties on petrol and diesel. A similar argument can be made for "bads" that affect consumers' health, with potential social externalities (e.g. tobacco or alcohol), though the extent of such externalities is controversial (e.g. Jeanrenaud and Soguel, 1999; Guhl and Hughes, 2006).

\section{...but are an inefficient way of reducing income inequality. .}

41. Many OECD countries use differentiated consumption taxes to reduce inequality by exemptions and zero ratings on certain goods and services, for instance, basic groceries. The reduced efficiency linked with VAT exemptions should be weighed against the benefits associated with the public policy of exempting these goods and services. Deaton and Stern (1986) show that direct lump-sum payments to households, depending only on their socio-economic characteristics, are better for both equity and efficiency, while Ebrill et al. (2001) argue that direct targeted transfers to low-income households are more effective in enhancing equity than VAT exemptions/zero-ratings. The reason is that higher income households consume relatively more of the low-taxed goods and therefore will benefit more from the lower rates than low-income households.

... and would not be a solution to the underground economy...

42. A high uniform consumption tax, such as VAT, will encourage certain easily hidden activities to move into the underground economy. Some countries have taken the view that the way to deal with this is to apply a lower rate of tax to the goods and services these activities produce. However, it is difficult to exactly identify the goods and services that fall into this category, especially since many consumer purchases can be made with cash. Also, it should be noted that even the underground economy pays a nonzero rate of VAT as it is unable to reclaim the VAT paid on its inputs. In these circumstances it may be administratively easier to counter the incentive to enter the underground economy by a combination of avoiding excessively high rates of tax, having a fairly high VAT threshold and a well-targeted audit programme than by a multi-rate VAT system. Moreover, the introduction of lower rates risk being a slippery slope, likely triggering rent-seeking activities by producers of other goods and services also wishing to be covered by reduced rates.

...so the argument for single rate VAT is strong.

43. Overall, therefore, there are valid arguments for the use of specific consumption taxes in particular cases, mainly related to the environment and work incentives. However, the arguments related to equity are much weaker, because alternative approaches to the problem are more effective. Also, none of the arguments provide against a broad-based single-rate VAT or sales tax. Indeed, they suggest that such a tax should be the main source of consumption tax revenues.

44. One measure of the broadness of the tax base, the extent of reduced rates and the effectiveness with which taxes are collected is the so-called "C-efficiency" for VAT, which expresses the revenue collected from the actual VAT in a countries as a proportion of the revenue that would be raised if the main 
rate of VAT were applied to all consumption. A high ratio suggests a uniformly applied VAT on a broad base with effective tax collection while a low ratio may indicate an erosion of the tax base either by exemption or reduced rates, poor compliance or poor tax administration or a combination of these. In 2003, this ratio varied between 100\% (New Zealand) and $31.8 \%$ (Mexico) (Figure 13).

\section{[Figure 13. C-efficiency for VAT (Average 2002-2004)]}

\section{The international dimension}

45. It is also important to consider the international dimension when assessing the advantages and disadvantages of consumption taxes. Higher consumption taxes in one country may induce individuals to consume in countries with lower taxes, though cross-border shopping is relatively small-scale except in cases where large population centres are close to a border or the tax differences are very large (which happens most commonly for excise duties on tobacco and alcohol). However, consumption taxes have the advantage of mainly being 'destination based', so that the taxes are refunded on exports and applied to imports. Thus, aside from cross-border shopping (including some cases of e-commerce sales to final consumers), VAT and other destination-based consumption taxes do not affect the pattern of international trade. ${ }^{12}$

\subsection{Taxes on property}

46. Property taxation in OECD countries takes four main forms: recurrent taxes on land and buildings, taxes on financial and capital transactions, taxes on net wealth and taxes on gifts and inheritances. These taxes generally share the aim of taxing the relatively wealthy and reducing inequality. However, they vary widely in their effectiveness and their distortionary costs.

Recurrent taxes on land and buildings have a small adverse effect on economic performance...

47. Recurrent taxes on land and buildings (especially residential buildings) are generally argued to be more efficient than other types of taxes in that their impact on the allocation of resources in the economy is less adverse. This is because these taxes do not affect the decisions of economic agents to supply labour, to invest in human capital, to produce, invest and innovate to the same extent as some other taxes. This conjecture is supported by the new empirical work undertaken in this project (see Section 4). Another advantage of property taxes is that the tax base is more stable and the tax revenue generated from this tax is therefore more predictable than for revenues obtained from labour and corporate taxes, partly due to less cyclical fluctuation in property values (e.g. Joumard and Kongsrud, 2003). Also, as real estate and land are highly visible and immobile these taxes are more difficult to evade, and the immovable nature of the tax base may be particularly appealing at a time when the bases of other taxes become increasingly internationally mobile. Property taxes also encourage greater accountability on the part of government, particularly where they are used to finance local government. Property taxes, with regular updating of valuation (which, with modern technology, is now feasible), can also increase the progressivity of the tax system (for example, by the exemption of low value properties), provided that special arrangements are made to reduce the liquidity constraints that the tax may imply for the relatively small number of people with low incomes and illiquid assets.

12 Recently there has been an increasing trend in VAT fraud linked to international trade, taking advantage of tax refund on exports from one country to another, so called "carousel fraud". This has involved substantial revenue losses for some (mainly European Union) countries and has resulted in the introduction of a number of strong measures to improve enforcement. 
... and they could contribute to the usage of underdeveloped land...

48. The design of property taxes on land and buildings can also be used as an instrument to affect land development and land use patterns. For example, low taxes on vacant property and undeveloped land can encourage the under-utilisation of land which may lead to a reduced supply of land for housing particularly in urban areas. ${ }^{13}$ Linking the assessment value to market value may increase incentives for developing land as market prices also reflect the development potential of land. But, in many OECD countries the assessment values of land lag substantially behind the actual development in land prices generating gaps between taxable land values and current land prices, which are politically difficult to close (e.g. Finland, the United Kingdom). ${ }^{14}$

\section{...while preferential housing tax treatment may distort capital flows}

49. As described in Section 2, owner-occupied housing has a favourable tax treatment relative to other forms of investment in many OECD countries through reduced tax rates or exemption for imputed rental income, mortgage interest payment deductibility and exemptions from capital gains tax. While the favourable treatment of owner occupation is often justified by the specific nature of housing and the positive externalities for society associated with its consumption (OECD, 2005a), they may distort the flow of capital out of other sectors and into housing. They can also reduce labour mobility and thus the efficient allocation of labour. In these circumstances, raising taxes on immovable property could improve economic efficiency and growth. The distortion between housing and other investments should be removed by taxing them in the same way: taxing the imputed rent and allowing interest deductibility. However, most OECD countries do not tax imputed rent at all, while those that do often under-estimate the rental value. In such circumstances, the denial of mortgage interest relief and the use of property taxes can provide a 'second best' approach, though local government control over property taxes makes it difficult in many cases to implement this approach in a co-ordinated fashion.

By contrast, taxes on financial and capital transactions are highly distortionary...

50. It is always less distortionary to tax the income and services provided by assets than the transaction involved in acquiring or disposing of them. This follows from the Diamond and Mirrlees (1971) result that taxes on intermediate transactions are inefficient, in the sense that the same revenue and distributional effect can be obtained at a lower distortionary cost by taxing income (including capital income) or consumption (consumption of housing services). The lower distortionary effect arises because both transaction taxes and taxes on income/consumption discourage the ownership of the assets, but the transaction taxes have the added distortionary cost of discouraging transactions that would allocate these assets more efficiently. For example, they discourage people from buying and selling houses and so discourage them from moving to areas where their labour is in greater demand. In fact, the distributional effects of transaction costs are probably also less desirable, as the tax falls more heavily on people who trade more frequently, such as people who need to move frequently for their jobs. Nevertheless, governments have found these taxes attractive for two reasons: they are relatively easy to collect and they compensate for the difficulties of applying VAT to the financial sector. Capital gains taxes, which are paid only upon realisation, suffer from some of the same shortcomings as taxes on intermediate transactions. ${ }^{15}$

13 For instance, in the Barker Review (Barker, 2006) of the land use planning system of England a set of recommendations dealt with the more efficient use of land where, among other things, changes were suggested to encourage business property to be kept in use and to provide incentives for the use of vacant previously developed land.

14 In many countries, these taxes are set at the local level which adds to the difficulty to reform them.

15 However, as discussed in Section 3.3, below, capital gains taxes also have advantages. 
...net wealth taxes are potentially less distortionary...

51. In principle, net wealth taxes can be used to redistribute income from the wealthy if they are based on total net wealth and have an exemption level that is high enough to exclude the life-cycle savings of all but the wealthy. They are also a very useful backup to personal income taxes since they provide tax authorities with information that enables them to identify inconsistencies between income flows and wealth held by taxpayers. However, these taxes discourage savings of the people to whom they apply, and may encourage people to move their wealth offshore, though these arguments apply just as strongly to taxes on transactions (which also distort the allocation of assets, as explained above). In practice, net wealth taxes often exempt certain assets, such as pension fund assets, thus distorting the portfolio choice and providing a method of tax avoidance: borrowing money (that will reduce net wealth) to purchase tax exempt assets.

\section{... and inheritance taxes are even less distortionary.}

52. Inheritance taxes are rather like net wealth taxes, except that they are levied only at the end of a person's life. This has the advantage of avoiding the taxation of most life-cycle savings. Inheritance taxes may also be seen as a way of taxing income or capital gains that were not taxed while the person was alive. Also, as argued by Auerbach (2006), these taxes have less distortionary effects than annual wealth taxes because a large part of inheritances are unplanned (being a hedge against the uncertain date of death). As with wealth taxes, it makes sense to have an exemption level that avoids taxing the majority of people who leave small inheritances. This reduces the number of people affected without losing much of the potential revenue. As one method of avoiding this tax is to make gifts during one's lifetime, a gift tax is a useful anti-avoidance measure although it could reduce growth by delaying the transfer of assets between generations. Most countries that have an inheritance tax, levy it on the inheritors, as a function of their individual inheritance but a few levy it on the value of the deceased person's estate. The advantage of levying it on the individual inheritor is that: $i$ ) it encourages distribution of wealth to larger number of inheritors, each of whom has a personal exemption; and ii) it allows the rate to vary between different inheritors.

53. These brief descriptions demonstrate the wide variety of property taxes and their effects on economic efficiency. One important set of differences between them is the way that they treat different classes of assets differently, including the different treatment of real and financial assets. Recurrent taxes on immovable property obviously affect only one class of real assets, while net wealth taxes typically exempt certain types of assets, particularly pension rights but sometimes other assets as well. Also, taxes on financial and capital transactions usually apply lower rates to financial transactions than they do to the transfer of land and buildings. It is generally thought that differences in tax treatment within a class of closely substitutable assets cause greater changes in behaviour. For example, financial assets are generally more substitutable for each other than are real assets and so are more responsive to differences in tax treatment. However, this does not necessarily mean that differences in tax treatment between financial assets are more damaging for growth, as the mix of financial assets may be much less important for growth than the mix of real assets, for example between housing and business assets.

\subsection{Personal income taxes}

54. This section focuses on personal income tax and social security contributions, as these are the main ways in which incomes are taxed in OECD countries, and examine their impact on GDP. The following aspects of these taxes are examined: average and marginal tax wedges; tax progressivity; top marginal income tax rates; effective taxes on returning to work and extending hours of work; and taxes on capital income. 


\section{Average and marginal tax wedges are likely to affect labour utilisation and productivity}

55. Taxes on labour such as personal income taxes and employers' and employees' social security contributions can potentially have adverse effects on labour utilisation by affecting both labour supply and labour demand (see Box 3 for an overview of recent OECD evidence). Labour taxes affect labour supply through both the decision to work (the extensive margin) and average hours worked (the intensive margin) (for an overview see Meghir and Phillips, 2007, Koskela, 2002). A decrease in labour taxes can have both a substitution and an income effect ${ }^{16}$ on participation and hours worked, with the net effect on labour supply being an empirical matter. Labour taxes also influence firms' cost of labour especially when the tax burden cannot be shifted on to lower net wages. In this case, lower taxes bring down labour costs and firms respond by increasing labour demand (Nickell, 2004; Koskela, 2002; Pissarides, 1998; Layard et al. 1991). ${ }^{17}$ In equilibrium, employment and average hours worked can, therefore, be affected by changes in personal income taxes and contributions.

56. It has been argued (e.g. Disney, 2004) that social security contributions have a smaller impact on labour supply than other taxes because the eventual social benefits that workers receive are related to the amount of contributions that they have paid. However, in many countries there is only a loose relationship between the amount of social security contributions paid and the amount of benefits received. Indeed, the empirical analysis for this paper found only weak evidence that employees' social security contributions have less of an impact than personal income taxes in terms of reducing GDP per capita. ${ }^{18}$ One reason for the difficulty to identify such differential effects in the data could be that the relationship between contributions and benefits varies widely across OECD countries. As well, repeated reforms in social security schemes have sometimes made the link between contributions and benefits even less evident, increasing the tax character of contributions.

57. Empirical studies have found hours worked to be only modestly responsive to labour taxes while participation is much more responsive to them (e.g. Heckman 1993; Blundell et al. 1998). Most empirical studies also find that the estimated elasticity of hours worked with respect to the after-tax wage is very small (close to zero) for men while for women/second-earners it is positive (Blundell and MaCurdy, 1999; Klevmarken, 2000; Evers et al. 2006; Alesina et al. 2005b; Causa, 2008). As women tend to be more responsible for child care or other non-market activities (providing therefore a closer substitute for market work than is the case for men) the labour supply decision of women tends to be more responsive to taxes than that of men. Studies looking at employment in various partial equilibrium models controlling for other institutional characteristics have found that high labour tax wedges curb employment by raising labour

16 The substitution effect of a decrease in labour taxes would increase labour supply as the reward for additional work has increased, while the income effect would reduce labour supply as it increases household income and thus increases the demand for leisure.

17 There is evidence that high labour taxes at the lower end of the earnings distribution price low-skilled, lowproductivity workers out of work, especially when these taxes interact with relatively high (statutory or contractual) minimum wages, since this limits the possibility of increases in non-labour costs being passed onto lower net wages (OECD 2007a).

18 Attempts have been taken to empirically assess the effect of social security contributions on GDP per capita by splitting personal income taxes into social security contributions and other personal income taxes. In some of these regressions, there was some indication that social security contributions are less harmful to GDP per capita than personal income taxes, with this difference being primarily driven by the less adverse effects of social security contributions levied on employees. Although these findings were significant in some specifications, they were not robust to slight changes in the sample or year coverage, or to minor redefinitions of the indicators. 
costs (Daveri and Tabellini, 2000; Koskela, 2002; Nickell et al. 2003; Prescott, 2004; Nickell, 2004; Bassanini and Duval, 2006). ${ }^{19}$

58. To the extent that labour taxes affect the relative price of capital and labour this could lead to a reallocation of inputs within and between firms and/or industries that could have transitional growth effects. For instance, a change in the relative factor price could lead to less usage of one of the production inputs (or possibly both) in a firm and/or industry. It is possible that all inputs not used in this firm/industry are either re-allocated to other less productive firms/ industries or not used at all, thereby lowering the efficiency in the use of production inputs, i.e. the so-called total factor productivity (TFP) growth. ${ }^{20}$ Indeed, new empirical results based on industry-level data for a sub-set of OECD countries, find some evidence that employer and employee social security contributions (SSC) negatively influence TFP. The analysis also provides weak hints that this effect tends to be stronger in countries with sizeable administrative extension of collective wage agreements (for details see Box 4).

\section{Box 3. Existing OECD evidence on the effects of personal income taxes}

The 2007 reassessment of the OECD Jobs Strategy explored the direct impact of taxation and possible interactions between taxation and other policies on employment and unemployment (the extensive margin of labour supply). After controlling for other policies (e.g. product market regulations, employment protection legislation, union density and corporatism, childcare and leave weeks) the tax wedge between labour cost and take-home pay is found to have a negative effect on the employment rate: According to the results from the baseline specification, in the study a ten-percentage-points reduction of the tax wedge in an average OECD country would increase the employment rate by 3.7 percentage points (OECD, 2005b). Furthermore, tax incentives for second-earners to start working, either full or part-time, are found to have a significant impact on prime-age female employment rates.

Family taxation may discourage labour market participation of second-earners due to effectively heavier taxation of married women relative to that of men and single women in many OECD countries (Jaumotte, 2003). The high effective taxation of second-earners is partly explained by the existence of a dependent spouse allowance and of other family-based tax measures in many OECD countries, which are lost if both spouses work. Taxes also influence female participation through the progressivity of the income tax system which is likely to reduce employment and hours worked of second-earners in the case of joint family taxation. ${ }^{1}$ This suggests that a more neutral tax treatment of second-earners could raise female participation. A combination of taxes and certain means-tested benefits such as child tax credits can create so-called "inactivity traps" where available employment opportunities become financially unattractive. In such cases an increase in gross in-work earnings fails to translate into a sufficient net income increase to justify starting work due to higher taxation and benefit withdrawals (Immervoll and Barber, 2005). This discourages labour market participation by certain groups, especially lone parents and second-earners.

The OECD project on factors explaining differences in hours worked (OECD, 2007f) considers the impact of taxes on hours worked (the intensive margin of labour supply). The theoretical net effect of the impact of labour taxes on labour supply is unclear. Taxes reduce labour supply through the substitution effect while the income effect raises labour supply. The study suggests that a high marginal tax wedge on second-earners is a key factor in explaining the relatively low working hours among this group. This finding is supported by disaggregated empirical evidence showing that the marginal tax wedge has a considerably stronger impact on the hours worked by women than on those worked by men. A one percentage point increase in the marginal rate is estimated to reduce the hours worked by women by around $0.7 \%$ whereas for men the impact of a same increase in the tax rate is close to zero (Causa, 2008).

The OECD study on the determinants of tertiary education shows that the rate of return to education, measured

19 The magnitude of the impact of taxes varies widely across studies but, excluding the high estimates, Nickell (2004) found that a 10 percentage point rise in the tax wedge reduces employment by around $1 \%$ to $3 \%$ of the working-age population.

TFP measures the change in output that cannot be accounted for by a change in inputs and is thus a measure of how efficiently the inputs are used. 
by the private internal rate of return (IRR), is an important factor driving the demand for tertiary education and human capital formation (Oliveira Martins et al. 2007). This measure summarises the economic incentives to take up tertiary education and tax policies can affect these incentives through their effects on the opportunity costs of taking up tertiary education (i.e. foregone earnings) and net wages after graduation (as well as, to a minor extent, on expected unemployment and pension benefits). Oliveira Martins et al. (2007) suggests that the impact of taxes on investment in tertiary education can be sizeable. The policy simulations show that a five percentage point reduction in marginal tax rates increases the IRR which leads to an average 0.3 percentage points increase in tertiary education graduation rates.

1. This effect is likely to be even stronger when child care costs are taken into account, though empirical cross-country evidence of this is not yet available.

59. It is also possible that labour taxes influence foreign direct investment adversely by increasing labour cost in the host country. For instance, Hajkova et al. (2006) found that the impact on FDI of labour taxes is generally substantially larger than that of cross-border effective corporate tax rates (see below). ${ }^{21}$ This can hinder technology transfers and spill-overs of best practices from multinationals to domestic firms, thereby reducing TFP.

\section{Tax progressivity may affect both labour utilisation and productivity}

60. The notion is accepted in all countries that progressive income taxes play a role in achieving a more equal distribution of income and consumption. However, it is also widely acknowledged that progressivity has the undesirable effect of distorting individual decisions to supply labour and invest in human capital. There are a number of ways of defining progressivity. In this study, a progressive tax system is defined as one in which the average tax rate increases with income or, equivalently, in which the marginal tax rate is higher than the average tax rate at any income level. ${ }^{22}$ While there is obviously a link between marginal and average tax rates - the average rate increases (falls) with income when the marginal tax rate is above (below) the average rate - it is possible to vary the two independently to some extent. For example, the average tax rate can be reduced for all taxpayers without altering the marginal tax rates of all but those on the lowest incomes by granting a general tax credit for a fixed amount.

61. Growth regressions undertaken for this study point to sizeable adverse effects of progressive income tax schedules on GDP per capita (see Arnold, 2008 for details), which go over and above the effects working through human capital accumulation. For example, consider the average OECD country in 2004 , which had an average personal income tax rate of $14.3 \%$ and a marginal income tax rate of $26.5 \%$. If the marginal tax rate were to decrease by 5 percentage points in this situation, thus decreasing the progressivity of income taxes, the estimated increase in GDP per capita in the long run would be around $1 \%$. Given that this analysis controls for human capital, this effect could originate from the responsiveness of labour supply to progressivity. However, it is also possible that it partly reflects higher entrepreneurship and risk-taking, if the measure of progressivity used in this project is correlated with progressivity at higher levels of income (see below).

21 The effect on FDI of a one standard deviation change in the tax wedge on labour income is around ten times larger than the effect of a similar change in the marginal and average cross-border effective tax rate.

22 From a policy perspective it is the overall progressivity of the tax system which is relevant. Thus, for example, the potential regressive effects of VAT may be affected by progressive elements in other parts of the tax system. 
62. These results suggest a non-trivial trade-off between tax policies that enhance GDP per capita and distributional objectives. However, there can be cases where this trade-off does not exist (see discussion of in-work benefits below).

\section{The interaction between labour income taxes and the benefit system}

63. It is possible that the interaction of the tax and benefit systems can create high average and marginal effective tax rates for certain groups, affecting labour force participation, hours worked and employment. For example, these joint effects can influence the financial reward from moving from inactivity to low-paid work and the incentives to re-enter the labour market - particularly for low-skilled low-pay workers and second-earners - after a period of unemployment. These high effective tax rates may have sizeable consequences on participation and employment, particularly if upward wage mobility is relatively limited at the bottom of the wage distribution.

64. Recent tax reforms in some OECD countries have aimed to reduce disincentives to participate in the labour market, especially for low-income and low-skilled households, by introducing so called "inwork benefits" or "make-work pay policies". These benefits or tax credits which top up the earnings of low-income earners have had some success in reducing "inactivity traps" of some groups of workers (Meyer and Rosenbaum, 2001; Blundell et al. 2000; Card and Robins, 1998). For example, "in-work benefits" increase the income of relatively low-income households, thus reducing inequality, and may also improve efficiency if the gain in labour force participation outweighs the reduced hours of those already in work. $^{23}$ That said, these schemes must be carefully designed (OECD, 2005b) to avoid worsening the incentives of those in part-time work to increase hours and to progress in work by up-grading their skills, thereby creating "low-wage traps" while avoiding high budgetary costs. ${ }^{24}$ Thus, the two main ways in which the government can help people on low-incomes - by providing them with direct income support and by encouraging them to earn more - may be in conflict with one another (Adam et al. 2006a; 2006b). In addition, these benefits need to be financed which may imply raising some other taxes.

\section{Top marginal statutory rates mainly affect productivity}

65. Top marginal statutory rates on labour income have an ambiguous impact on TFP via entrepreneurship by affecting risk taking by individuals. On the one hand, high top statutory income taxes reduce the post-tax income of a successful entrepreneur relative to an unsuccessful one and can reduce entrepreneurial activity and TFP growth. On the other hand, high tax rates provide for increased risksharing with the government if potential losses can be written off against other income (tax payments), which may encourage entrepreneurial activity (Myles, 2008). However, Gentry and Hubbard (2000) suggests that the higher is the difference between the marginal tax rates when successful and unsuccessful (a measure of tax progressivity) the lower is risk-taking as the extra tax that applies to high profits is greater than the tax saving that is produced by losses, effectively reducing the strength of the risk-sharing effect.

23 In-work benefits conditional on employment encourages participation in the labour market and reduce the likelihood of "unemployment" or "inactivity traps". But, they also tend to increase marginal tax rates for workers earning relatively low wages, due to the phasing out of these in-work benefits. Therefore, in terms of their potential effect on labour supply, these benefit schemes trade off higher participation against lower working hours of certain groups already in work.

24 A similar "win-win" situation can also sometimes arise with other methods of encouraging low-wage workers into the workforce, such as targeted reductions in social security contributions. These are of course subject to the same caveat in terms of the implied budgetary costs. 
66. Industry-level evidence covering a sub-set of OECD countries suggests that there is a negative relationship between top marginal personal income tax rates and the long-run level of TFP (see Box 4 for details). The magnitude of the estimated impact of a change in top personal income taxes differs across countries depending on the composition of their business sectors, increasing with the proportion of industries with structurally high entry rates. One possible policy implication may be that countries with a large share of their industries characterised by high firm entry (or wishing to move in this direction) may gain more from lowering their top marginal tax rate than other countries. However, it is likely that some other policies and institutional settings, such as product market regulation, have a more direct impact on entrepreneurship (Scarpetta and Tressel, 2002; Brandt, 2005; Conway et al. 2006). Additionally, the magnitude of the impact of tax reform may depend on the stance of these policies. Indeed the empirical analysis shows that the negative impact of top marginal tax rates on TFP is stronger in countries with a high level of the OECD indicator of product market regulation (PMR) ${ }^{25}$, suggesting complementarities between taxation and product market policies. ${ }^{26}$

\section{Box 4. Estimating the effect of labour taxes on total factor productivity (TFP)}

Gauging the direct effect of taxation on TFP based on industry-level data is difficult as available tax indicators are not differentiated by industries, although their impact may vary across industries. An indirect way to test for these tax effects is to see whether some industries are more affected by taxes due to some salient industry characteristics, such as technology or organisational features (for a detailed overview of this approach see Vartia, 2008). To test this, the analysis identifies industry-specific characteristics relevant for different tax policies and examines the interaction between these characteristics and the appropriate taxes. This interaction term is then used in the empirical model as the main variable of interest together with other relevant variables to explain changes in TFP (see e.g. Rajan and Zingales, 1998). For example, the estimation assumes that one channel through which labour taxes affect TFP is industries' labour intensity, while top marginal taxes affect TFP through the channel of firm entry. If the results of the econometric analysis support the hypothesis that the negative impact of taxes on TFP is stronger in certain industries due to these salient characteristics, then the estimated coefficient of the interaction term should be negative whereas if tax incentives have a stronger positive effect on TFP in industries with certain characteristics, the coefficient should be positive. One important caveat to this approach is that the estimated effect only captures the effect of a tax working through a specific channel. Any direct effect of the specific tax on TFP (unrelated to the industry characteristics) is captured in the fixed effects. TFP at the industry-level is calculated as the "Solow-residual" from a production function where the factor shares in the production function are proxied by the cost shares in value-added. The empirical analysis is based on a model that captures technological catch-up with the leading firms/industries and persistence of TFP levels over time. The same empirical approach is used in assessing the effects of corporate taxes on TFP. In general, this empirical approach provides reliable findings about the qualitative effects of various taxes on TFP, but the quantitative effects should be interpreted with caution. The main empirical results of the effect of labour taxes on TFP, as summarised in Table 6, are (see Vartia, 2008 for details):

Employer and employee social security contributions (SSC) have a more negative influence on TFP in industries that are relatively more labour intensive (Columns 1,2). However, the magnitude of the effect of SSC on the long-run level of TFP is estimated to be relatively small.

Top marginal personal income tax rates have a more negative effect on TFP in sectors characterised by high firm entry rates (Column 3). A simulation experiment indicates that the effect of a reduction of the top marginal tax rate from $55 \%$ to $50 \%$ on the average yearly TFP growth rate (over 10 years) would be 0.05 percentage points larger for industries with the median firm entry rate than for industries with the lowest level of firm

The PMR indicator includes, among other things, measures of the administrative burden on firms and regulatory barriers for start-ups.

This finding may reflect that potential entrepreneurs weigh the total cost against the potential return of starting up a business. Since taxes add to cost on top of the regulatory costs, the overall cost is increased, which may tilt the balance towards not becoming an entrepreneur in business environments where taxes are high at the same time as regulations are burdensome. 
entry. Under the assumption that the effect of top marginal rates are close to zero in industries with the lowest level of firm entry, this may be interpreted as a median effect. The effect of this tax reduction on TFP depends on the industry structure and this tax cut would increase the average annual productivity growth rate by 0.06 percentage points more in an industry at the 75 th percentile of firm entry than in an industry at the 25th percentile of the distribution of firm entry.

There is weak evidence that the negative effect of SSC tends to be stronger in countries with a sizeable administrative extension of collective wage agreements to non-unionised firms (Column 4). The extension of wage agreements may magnify the effects of SSC increases on labour cost by making it more difficult to shift the burden of this increase on workers' wages and more so in industries that are more labour-intensive.

[Table 6. Estimated effects of labour taxes on TFP: Industry-level]

\section{Capital income taxes may affect investment and entrepreneurship through savings and firms' financing}

67. Taxes on personal capital income may affect private savings by reducing their after-tax return. However, as discussed in Section 3.1, the effects of this on savings, and particularly on investment, are uncertain. Nonetheless, differences in the personal income tax treatment of different forms of savings can be expected to distort the allocation of savings and reduce the growth potential of the economy. As most OECD countries do favour certain types of savings (such as owner-occupied housing, private pension funds) over others (such as bank deposits), there is scope to increase growth by reducing these distortions.

68. High capital gains taxes may affect both the demand for venture capital through entrepreneurs' career choice and the supply of funds (e.g. Poterba, 1989). Since venture capital is one important source for financing high-technology firm start-ups, financial support for these start-ups may be hindered by high capital gains tax, thus lowering the potential contribution of new firm entry to TFP growth. However, there is little empirical evidence of this link. More generally, policymakers face difficult choices in relation to capital gains taxes (see OECD, 2006c). In particular, exempting capitals gains from taxation provides opportunities for tax avoidance by transforming taxable income into tax-free capital gains, but the application of capitals gains tax can "lock-in" investments and prevent the efficient reallocation of capital because (for reasons of practical administration) capital gains are taxed on realisation. It is, therefore, unsurprising that OECD countries differ widely in their taxation of capital gains.

69. The design of the capital income tax system and its interaction with corporate taxation may also influence firms' access to finance, which in turn can affect risk-taking and TFP (e.g. Feldstein, 2006). In most OECD countries, profits are taxed first at the corporate level and then at the personal level when they are distributed as dividends, and there has been a recent trend away from the use of imputation systems that give a credit at the personal level for taxes paid at the corporate level. Double taxation can create a bias towards financing investment with debt rather than equity, which may in turn discriminate against firms that have less access to debt financing. For instance, personal taxation of dividends has less influence on larger firms that can raise finance from foreign investors, who are generally not subject to the home country's personal taxes on dividends.

70. While the effects of high dividend taxes on financial structure are widely accepted, there is no consensus among corporate finance theorists on whether dividend tax cuts have a real effect on investment decisions or they are merely fully capitalised in share values (e.g. Auerbach, 2002). ${ }^{27}$

27 Under the "traditional" corporate finance view, firms' marginal source of finance is new share issuance and dividend tax cuts feed into firms' cost of capital and thus promote investment. The "new" view suggests that the marginal source of finance is retained earnings and that dividend tax reductions are capitalised into 
71. Tax design should try to reconcile the broad policy objectives of taxation (e.g. revenue raising potential, administrative simplicity and equity) with efficiency considerations. Thus, the tax system should, as far as possible, avoid encouraging economic behaviour that could influence market activity adversely. This generally requires a broad tax base and few differences in tax rates (OECD, 2006b). As discussed above, on the personal income side, some important design features are the tax unit/base (individual or joint family taxation), the progressivity of the tax schedule, tax compliance and the tax treatment of capital income which can have an influence on economic performance. But, one complexity is that reforms of personal income taxes are often difficult to evaluate in isolation from the rest of the tax and benefit system since changes in taxes often interact with existing benefits affecting the effective average and marginal tax rates.

72. The main purpose of family-based taxation is to increase vertical and horizontal equity in the taxation of households with different composition of income. One argument for equity being defined across households rather than across individuals is that the household is often the principal consumption unit. However, joint family taxation can create disincentives for (married) second-earners to enter the labour market and have adverse effect on GDP per capita. On the other hand, one problem with individual taxation is how to attribute non-labour income between the spouses, for instance, if it should be accredited to the spouse with highest income or if couples should be able to freely choose. While this has equity implications, it is unlikely to significantly influence economic behaviour. Thus, the choice between family and individual taxation involves a trade-off between equity concerns and the labour supply of secondearners which affects labour utilisation and GDP per capita.

73. The choice of tax schedule in a country is also likely to depend on how the trade-off between equity and tax distortions is valued. A flat tax system with few allowances and tax credits is generally simpler to administer and probably gives rise to fewer tax-induced distortions than other systems, but it puts less emphasis on redistribution (Box 5). By contrast, a highly progressive income tax system normally reduces incentives to work and to invest in human capital, although "in-work benefits" can improve work incentives for low-wage workers while increasing progressivity. High progressivity may also increase the incentives for tax avoidance and tax evasion and contribute to a growing shadow economy that reduces measured GDP, although it is arguable that the tax level is more important than its progressivity in this regard. This may reduce tax revenues and undermine the fairness of the system. There is also a possibility that high top marginal rates will increase the average tax rates paid by high-skilled and high-income earners so much that they will migrate to countries with lower rates resulting in a "brain-drain" which may lower innovative activity and productivity.

74. Another important issue is the taxation of capital income. Over the last 50 years, the traditional approach to income taxation was the comprehensive income tax, which applies a single tax schedule to a person's (or couple's) total income, combining labour income with all the different forms of capital income. However, many OECD countries have moved away from this approach to varying extents, by applying lower rates of tax to some or all capital income (OECD 2006b). A particularly interesting example of this is the dual-income tax system (Box 2), such as that used in most Nordic countries, which taxes all capital income at a single flat rate that is lower than the top rates applied to labour income. However, this creates an incentive for entrepreneurs to disguise labour income as capital income. The dualincome tax also raises equity concerns but it has several advantages: it reduces any disincentive to save; it may help offset the fact that capital income taxes are usually applied to the nominal rather than the real return on savings; it reduces the incentive for capital owners to move their savings offshore in an attempt

share values, but do not affect investment. Recent empirical evidence based on micro data shows that none of these extremes applies to all firms (Auerbach, 2002). 
to avoid taxation; and it reduces the scope for tax arbitrage between different sources of capital income. Several other countries have adopted a 'semi-dual' approach, in which different types of capital income are taxed at different rates. Countries may have different efficiency reasons for taxing interest, dividends and capital gains at lower rates than labour incomes. For example, many countries give special treatment to capital gains because of their association with risk-taking and do not see as great a necessity to reduce the general taxation on savings.

\section{Box 5. Flat personal income tax reform experiences}

Estonia was the first European country that introduced a flat tax levied at a rate of $26 \%$ on personal (and corporate) income in 1994 . The flat rate is $21 \%$ in 2008 , but Estonia is in the process of reducing the rate gradually to $18 \%$ from 2011 onwards. The other Baltic States soon followed the Estonian example, as did several other Central and Eastern European countries - among those is Russia where a flat personal income tax rate of $13 \%$ was introduced in 2001.

The Slovak Republic is the first OECD country to have a flat tax. The country introduced a 19\% rate in 2004 that applies to both corporate and personal income, and which is also used as the value-added tax rate. The tax reform in the Slovak Republic broadened the tax base by eliminating almost all tax reliefs but increased the basic allowance. At the same time, the Slovak government reduced social assistance benefits and shifted the tax burden from direct to indirect taxation. They continue to levy high health and other social security contributions. Since 2006, also Iceland applies a flat income tax rate on labour income above a threshold (ISK 1080067 in 2007). The central government rate in 2007 is $22.75 \%$ and the local government's income tax rate varies between $11.24 \%$ and $13.03 \%$ between municipalities. In 1998, Iceland levied a surtax of $7 \%$ on higher incomes, but this rate has been gradually reduced over time and was abolished from 2006 onwards. Iceland levies a low fixed amount of employee SSC and employer SSC are levied at a low rate of $5.34 \%$ on gross wages in 2007 . The Czech Republic has introduced a flat personal income tax in 2008. In addition, flat tax systems have been and still are discussed in several other OECD countries.

A common feature of all flat tax proposals is that the introduction of a single rate is combined with the abolition of all or most tax allowances and tax credits. This might improve the tax system's efficiency, especially if a low flat tax rate would be levied. Efficiency would be improved even further if the same flat rate is introduced for both personal and corporate income as this reduces or even removes the tax incentives for income shifting between the personal and the corporate sector. However, identical tax rates are not sufficient for these incentives to disappear, as they also depend on the definition of the tax base.

Progressivity in flat tax systems is achieved by means of a basic allowance or basic income provision. This might have a positive effect on redistribution, both because the value of deductions in a progressive tax rate system are increasing with income and because high-income persons are generally in a better position to take advantage of these allowances than are low and medium income persons. In addition, it is often argued that lowering tax rates stimulates the economy and leads to increased employment, which will normally have a positive effect on income distribution as well. On the other hand, the static/first-year effects of flat tax reforms will probably give by far the largest tax cuts to high-income individuals but also lowincome earners might gain if the basic allowance is increased. It is however the middle-income earners that most likely will be worse off after a flat tax reform.

In addition to the personal income taxes, most countries levy social security contributions only on labour income (and not, for instance, on capital income). Social security contributions then undermine the 'flatness' of the tax system if they don't confer an actuarially fair entitlement to a possibly contingent future social benefit. One could then say that flat tax systems turn into (semi-) dual income tax systems with proportional instead of progressive taxation of labour income.

In some countries, having a flat tax on capital and labour income might require a rather high tax rate, which would reduce the tax system's efficiency and might raise problems because of the international mobility of the tax bases. On the other hand, implementing a rather low flat tax rate would undermine the benefit system in many OECD countries and would undermine income redistribution.

Source: OECD (2006b) "Fundamental Reform of Personal Income Tax“.

75. The taxation of dividends is an area of special interest, not only because of recent moves away from imputation systems but also because of its links with corporate taxation. Some countries, such as Finland, moved away from imputation for publicly quoted companies partly because they wished to use the money saved to reduce the rate of corporate tax, in order to attract foreign direct investment. Moves of this sort increase the taxation of profits at the personal level in the country of the shareholder's residence and reduce the taxation of profit at the corporate level in the country in which the profits arise. In general in an open economy, a residence-based capital income tax (like dividend tax) may discourage savings without 
affecting domestic investment whereas a source-based capital income tax (such as the corporate tax) tends to reduce and distort domestic investment. The choice between these two approaches to the taxation of profits depends to some extent on whether the policy aim is to raise the level of domestic investment or saving.

76. Also, to encourage saving most OECD countries currently give tax incentives to certain forms of private saving, for example pensions (e.g. Yoo and de Serres, 2004). While these incentives are likely to lead to changes in the composition of savings there is little evidence that they result in increases in overall private savings and since the tax breaks involved are likely to reduce public savings, their effect on GDP is at best uncertain (OECD, 2006b, Box 6).

\section{Box 6. Tax-favoured pension plans}

Economic efficiency in the taxation of savings requires that, in the absence of an existing market failure, tax policy should not affect individuals' decisions about what assets they save in. But the government may want to encourage people to save in specific retirement saving instruments and many OECD countries use some type of tax incentives to encourage the development of private pension saving. These incentives may be put in place to reduce "moral hazard" of individuals who may be tempted to not save enough for their retirement during their working life and instead relying on the social safety net. Also, countries with an ageing population can find that these tax incentives are a way to smooth the transition from "pay-as-you-go" financing to "pre-funding" of pension schemes. One potential problem with taxing different forms of savings differently is that it results in saving decisions being driven not by underlying returns but by the tax system.

A savings scheme is usually considered as being taxed favourably when its tax treatment differs from a regime that treats all sources of income equally from a fiscal standpoint (the so called "comprehensive income tax regime"). There are several ways in which tax incentives for pension savings can be provided. For instance, in an "exemptexempt-taxed" (EET) scheme both the funds contributed and the accrued return on the accumulated funds are exempted from taxation while the benefits are treated as taxable income upon withdrawal. But the tax incentives do not necessarily need to imply a tax-deferral, under a "taxed-exempt-exempt" (TEE) scheme the income tax on pension savings is pre-paid while the accrued returns and withdrawal is tax-exempt. In practice, there is a whole range of possible tax combinations going from a scheme of "taxed-taxed-taxed" to "exempt-exempt-exempt", but most OECD countries apply some form of the EET regime (Yoo and de Serres, 2004). The net tax cost in terms of foregone tax revenues of the tax favoured schemes, or the size of the tax incentives to invest in a private pension schemes, varies across OECD countries. It ranges from 40 cents per dollar or euro contributed (Czech Republic) to around zero (Mexico and New Zealand). Despite the variation, most OECD countries incur a sizeable net tax cost. Half of the countries incur a tax cost of more than 20 cents, and it exceeds 10 cents in most OECD countries (Yoo and de Serres, 2004).

These tax advantages in pension savings need to be weighed against poor targeting since the moral hazard problem does not affect individuals whose expected pension income is well above the social safety net. Moreover, it is highly likely that the favourable tax treatment of pension savings only distorts the composition of savings without increasing the overall level of savings at the expense of tax revenues (OECD 2006b; Antolin, et. al. 2004; OECD 2004).

\subsection{Corporate income taxes}

77. Corporate income taxes are levied on the corporation as an entity rather than on the individuals who own the corporation. This section describes the effect of the main components of corporate taxation on GDP in OECD countries. The tax variables considered are: statutory and effective corporate rates (including depreciation allowances), cross-border effective rates, and R\&D tax incentives.

\section{Corporate taxation may affect capital formation...}

78. Corporate income taxes can affect the rate of capital accumulation and hence GDP per capita. Since firms' investment decisions are driven by the cost of and the expected return to investment projects, 
corporate taxes can have a negative effect on corporate investment by reducing its after-tax return. The extent of this effect can, in turn, be expected to depend on the degree of openness of the economy, with a more open economy likely to suffer more from an excessively high corporate tax than a more closed economy. ${ }^{28}$ It is also possible that taxes on personal capital income affect investment decisions by small firms that are only able to access domestic savings, but since most investment is undertaken by large firms with access to international funds, personal capital income taxes are likely to have a small effect on GDP. Foreign direct investment (FDI) is affected in a similar way as domestic investment by corporate taxation. However, it is also affected by the tax treatment of cross-border income (see below). Moreover, the effect of corporate taxes on capital formation through FDI can also depend on the size of the economy, with larger economies able to attract FDI aimed at supplying their large markets even if they maintain relatively high tax rates. Also, the proportionate effect of FDI on the domestic capital stock may be larger in smaller economies. The effect of corporate taxes on investment may also depend on other policies and institutions. For instance, tight product market regulations and a large administrative burden on firms can make firms' investment decisions less responsive to cuts in corporate tax rates as these administrative and regulatory barriers increase the adjustment cost of capital (Alesina et al. 2005a).

79. Empirical evidence obtained from both firm-level data covering a sample of 14 European OECD countries and industry-level data covering 21 industries in 16 OECD countries suggest that investment is adversely affected by corporate taxation through the user cost of capital (see Box 7). There are several empirical findings worth mentioning:

- Increases in the tax-adjusted user cost are found to reduce investment at the firm level and the effect on firm-level investment is stronger in more profitable industries. This indicates that the tax component of the user cost contributes significantly to the reduction in investment by disproportionately increasing the user cost for firms with a large tax base.

- Differentiating the impact of the tax-adjusted user cost across firms of different size (number of employees) and age, it appears that older firms' investment, irrespective of firm size, responds more strongly to corporate taxation through the user cost than younger firms' investment. There are two possible interpretations. One possibility is that young firms are generally less profitable than older firms and therefore have a smaller tax base. A second possibility is that young firms benefit from targeted exemptions or reduced rates.

- The firm-level sensitivity of investment to the corporate tax rate finds confirmation at the industry-level. Since the user cost of capital takes into account depreciation allowances that are deductible from firms' tax liability at the rate of the corporate tax, the magnitude of the influence of a change in capital depreciation allowances also depends on the level of corporate tax rates. 


\section{Box 7. Empirical evidence on the effect of taxes on investment}

The empirical results, both at firm and industry level, assessing the effect of taxes on investment are obtained by introducing the tax adjusted user cost in a standard investment equation with adjustment costs of capital (see Schwellnus, 2008 and Vartia, 2008 for details). The empirical approach is based on the user cost theory of capital which stems from a neoclassical investment model in which investment decisions are made to maximise the net present value of the firm (e.g. Hall and Jorgenson, 1967). In addition to the standard user cost components (the required rate of return to the investment, the economic depreciation rate and anticipated capital gain/loss due to a change in before-tax price of the asset) the tax-adjusted user cost takes into account taxes on profits and the present value of the tax savings from depreciation allowances. The industry-specific user cost is constructed as a weighted average of the asset specific user cost where the weights are the share of each asset in total industry investment. The advantage of framing the empirical analysis within the user cost theory is that estimations are closely linked to theory. But one disadvantage is that the tax effects on investment are not separable from the effects of the other components included in the user cost. The firm and the industry level investment equations are based on different non-linear specifications. At the firm level, a non-log specification including a quadratic term of the lagged investment-to-capital ratio capturing a non-linear adjustment of investment is used. The industry level equation is specified in log terms and the adjustment of investment is captured by the lagged investment-to-capital ratio. ${ }^{1}$

The main empirical findings at the firm-level, summarised in Table 7, are (see Schwellnus, 2008 for details):

Increases in the tax-adjusted user cost are found to reduce investment at the firm-level (Column 1). A simulation experiment indicates that a reduction of the statutory corporate tax rate from $35 \%$ to $30 \%$ reduces the user cost by approximately $2.8 \%$. This implies a long-run increase of the investment-to-capital ratio of approximately $1.9 \%$, given its long-run user cost elasticity of 0.7 .

The size of the negative tax effect on investment appears to be similar for small and large firms (measured by the number of employees). In contrast, only older firms' investment appears to be negatively affected by increases in the tax-adjusted user cost (Column 3). One possible explanation is that young firms are generally less profitable than older firms and therefore less affected by corporate taxation. The other explanation may be that among young firms there is a disproportionately high share of small firms that benefit from exemptions or reduced rates.

[Table 7. Estimated effects of corporate taxes on investment: firm-level]

The main results obtained at the industry-level, summarised in Table 8, are (see Vartia, 2008 for details):

The investment-to-capital ratio is negatively affected by increases in corporate taxation. The long-run user cost elasticity is estimated to vary between -0.4 and -1 , depending on the empirical specification. A simulation experiment indicates that a cut in the statutory corporate tax rate from $35 \%$ to $30 \%$ would increase the long-run investment-tocapital ratio by $1.0 \%$ and $2.6 \%$, depending on the specification. These are lower and upper bound estimates at the industry level and the firm-level estimate lies within this interval. The estimated effect of this tax reduction is equivalent to an increase in the average investment-to-value-added ratio by 0.2 to 0.5 percentage points.

The corporate tax rate enters non-linearly into the user cost formula and as a result the magnitude of the effect of a change in the tax depends on the level of corporate taxes. Countries with a higher corporate tax rate experience a somewhat larger negative effect from the same increase in the tax than countries with a lower tax rate.

The effect of a five percentage point increase in the net present value of the depreciation allowance (of both machinery and structures) is estimated to increase the investment rate by $0.9 \%$ to $2.5 \%$, depending on the empirical specification. ${ }^{2}$ Since the depreciation allowances are deductible from firms' tax liability at the rate of the corporate tax, the magnitude of the impact of a change in capital depreciation allowances also depends on the level of corporate tax rates.

[Table 8. Estimated effects of corporate taxes on investment: industry level]

1. In the firm-level data it is possible to capture the adjustment of the capital stock with a non-linear specification including a quadratic term, whereas at the industry level, capturing the adjustment of the capital stock with this specification is difficult. Therefore, the industry level analysis uses a log specification with the lagged dependent variable measuring the adjustment process.

2. The average value of the net present value of the depreciation allowance is $40 \%$ for structures and $78 \%$ for machinery. 


\section{... and productivity in several ways}

80. There are several channels through which corporate taxation can affect TFP. First, as with labour taxes, corporate taxes can distort relative factor prices resulting in a re-allocation of resources towards possibly less productive sectors (e.g. non-corporate sector) which may lower total factor productivity (e.g. Boersch-Supan, 1998). Second, complex corporate tax codes can cause high tax compliance costs for firms and high administrative burdens for governments, which absorb resources that could be used for productive activities, causing productivity and efficiency losses. Third, high corporate taxes may reduce incentives to invest in innovative activities by reducing their after-tax return. Fourth, to the extent that corporate taxes reduce FDI and the presence of foreign multinational enterprises they can hinder technology transfers and knowledge spill-overs to domestic firms (see below).

81. Also, corporate taxes distort corporate financing decisions, favouring debt over equity because of the deductibility of interest from taxable profits. This can affect TFP by distorting the allocation of investment between industries, favouring those that find it easy to raise debt finance and disadvantaging those that have to rely more on equity, such as knowledge-based industries that invest heavily in intangible property. Even within an industry this can disadvantage innovative fast-growing firms that may rely on risk capital more than other firms. This has led to the consideration of a range of fundamental corporate tax reforms in several OECD countries (Box 8). It is also possible that corporate taxes affect the allocation and reallocation of resources across firms which can play an important role in accounting for aggregate productivity. A similar problem can arise from the "lock-in" effect of capital gains tax.

\section{Box 8. Fundamental corporate tax reform}

Many policymakers in OECD countries are concerned about whether they can maintain their current levels of corporate income tax revenues, especially in the light of increasingly mobile tax bases, and how they can create a more attractive investment climate for domestic and foreign investors. They are also concerned about the distortions induced by their corporate income tax systems - the corporate income tax is likely to distort the total amount of investment and the type of investment projects that are undertaken, the corporate sources of finance (debt, newly issued equity or retained earnings), the location of the corporate tax base, the choice of a business legal form and the tax might have an impact on corporate mergers and acquisitions. Policymakers also look for ways to reduce corporate income tax complexity. In principle, these goals can be achieved through fundamental corporate income tax reform. However, in practice, fundamental reform is often difficult to implement because of the trade-offs between simplicity, efficiency and fairness considerations and because of the potential international tax consequences, transitional implications and tax revenue consequences.

The allowance for corporate equity (ACE) tax system - as, for instance, implemented in Belgium - provides a deductible allowance for corporate equity in computing the corporation's taxable profits. Similar to the deductibility of interest payments from the corporate income tax base, the allowance for corporate equity equals the product of the shareholders' funds (generally the company's total equity capital) and an appropriate nominal interest rate (interest rate on medium term government bonds). The allowance therefore approximates the corporation's "normal" profits. The corporate tax is then confined to economic rents because only corporate profits in excess of the ACE are subject to corporate tax. As a result, the ACE tax system does not distort the choice between debt and equity as sources of finance at the corporate level.

The allowance for shareholder equity (ASE) tax system - as implemented in Norway - exempts the normal return on equity from double taxation as well. However, it provides tax relief for the normal return on equity not at the corporate level as under the ACE tax system, but at the personal level instead. The ASE might be calculated as the value of the shares held by the household multiplied by an imputed return (interest rate on medium-term government bonds). As is the case for the ACE tax system, which is equivalent to a corporate cash-flow tax, the ASE tax is equivalent to a personal level cash-flow tax.

Governments might also implement other types of corporate income taxes as a full imputation system, the shareholder allowance for corporate equity tax system or the comprehensive business income tax (CBIT) system. The $\mathrm{CBIT}$, for instance, allows no deduction of either interest payments or the return on equity from taxable corporate earnings. Except for the CBIT rate, no additional taxes would be imposed on distributions to equity holders or on payments of interest. 
Finally, instead of taxing corporate income, government might implement a corporate cash-flow tax. Under a corporate cash-flow tax, income is taxed only when cash is received and costs are deductible immediately when purchases are made and interest costs are not deductible. The capitalisation of assets is therefore no longer required due to the immediate expensing of the investment and the economic depreciation of assets no longer has to be measured. A corporate cash-flow tax treats debt and equity symmetrically and so does not distort the firm's decisions on sources of finance.

Source: OECD (2007b) "Fundamental Reform of Corporate Income Tax".

82. The empirical findings at both firm- and industry-level suggest that there is a negative effect of taxes on TFP (see Box 9 for details). Allowing for heterogeneity in the tax impact across both firm size and age categories, it appears that the negative effect of corporate taxes is uniform across firms of different size and age, except that no such effects are found for firms that are both young and small. There are two possible explanations for this result. First, small firms benefit from exemptions and reduced rates of corporate taxes. However, this does not explain why small firms are negatively affected by corporate taxes after their initial five years of existence (i.e. after they become "old" according to the convention adopted here). A more convincing explanation, therefore, is that the category of young and small firms includes a large share of start-ups with low or zero profits, even in highly profitable industries. For these firms the effect of corporate taxes may therefore be negligible.

83. It is also possible that corporate taxes have a differential effect on firms that are in the process of catching up with the productivity performance of the best practice firms (catch-up firms) and firms that are falling behind (non catch-up firms), especially if profitability is higher in catch-up than in non catch-up firms. In this case, corporate taxes could have a particularly negative effect on innovation incentives for catch-up firms by disproportionately reducing their after-tax return to innovation. This conjecture is supported by empirical findings showing that only firms that are in the process of catching up with best practice are negatively affected by the statutory corporate tax rate (see Box 9 for details). These results suggest that lowering the corporate tax rate may be particularly beneficial for productivity growth of the most dynamic and innovative firms. This could be because such firms rely heavily on retained earnings to finance their growth.

\section{Box 9. Estimating the effect of corporate taxes and R\&D tax incentives on TFP}

As with labour taxes, the empirical approach to estimate the effect of corporate taxation on TFP is based on identifying industry-specific characteristics that are expected to cause a differential effect of corporate taxes on industry TFP (described in Box 4). More specifically, the estimation approach (both at firm and industry-level) assumes that one channel through which corporate taxes affect TFP is industries' corporate profitability (high returns). ${ }^{1}$ Furthermore, to assess the effect of tax incentives for R\&D expenditures and the resulting effect on TFP it is assumed that the channel through which these incentives influence R\&D differently across industries is the R\&D intensity of industries. ${ }^{2}$ Firmlevel TFP is calculated as the residual from the estimation of a logarithmic Cobb-Douglas production function using firm level data on value-added and labour and capital inputs while, as described in Box 4, industry-level TFP is measured as the "Solow-residual" from a production function. The empirical results draw on a specification that captures two empirical regularities, namely technological catch-up with the leading firms/industries and persistence of TFP levels over time (Scarpetta and Tressel, 2002; Griffith et al. 2006). As mentioned in Box 4, this empirical approach provides reliable qualitative indications regarding the qualitative effects of various taxes on TFP, though the size should be interpreted with caution.

The main empirical results concerning the influence of corporate taxes on TFP at the firm-level are (see Schwellnus, 2008 for details):

Lowering corporate taxes is estimated to boost firm-level TFP in profitable industries (Table 9, Column 1). A simulation experiment indicates that the effect of a reduction of the corporate tax rate from $35 \%$ to $30 \%$ on the average yearly TFP growth rate (over 10 years) would be 0.4 percentage points higher for firms in 
industries with median profitability than for firms in industries with the lowest level of profitability. Under the assumption that the effects of corporate taxation are close to zero for firms with the lowest tax base, this may be interpreted as a median effect. Given that trend TFP growth of OECD countries averaged around $1.1 \%$ over the period 2000-2005 (OECD, 2007e) the simulated increase in TFP growth due to a tax reduction would seem to be an upper bound estimate. The effect of this tax cut on TFP depends on the industry structure and this reduction would increase the average annual productivity growth rate by 0.4 percentage points more in an industry at the 75 th percentile of profitability than in an industry at the 25 th percentile of profitability.

The negative effect of corporate taxes is uniform across firms of different size and age classes, except for firms that are both small and young. This may either be due to some countries' exemptions or reduced rates targeted at start-up firms or to their low average profitability, which both reduces the amount of their effectively paid corporate (Table 9, Column 2).

Rising firms that are in the process of catching up with the technological frontier are particularly affected by corporate taxes (Table 9, Column 3). Even in sectors with low average profitability there is a subset of highly profitable firms that catch up with the technological frontier. These firms' tax base is large so that a high corporate tax rate increases their effective tax burden disproportionately relative to that of other firms.

\section{[Table 9. Estimated effects of corporate taxes on TFP: Firm-level]}

The main empirical results obtained at the industry-level are (see Vartia, 2008 for details):

Lowering corporate taxes is estimated to boost TFP in profitable industries (Table 10, Column 1). A simulation experiment indicates that the average effect (over 10 years) of a reduction of the corporate tax rate from $35 \%$ to $30 \%$ on the yearly TFP growth rate would be 0.08 percentage points higher for industries with the median profitability than for an industry with the lowest level of profitability. As mentioned above, this may be interpreted as a median effect. The effect of this tax cut on TFP depends on the industry structure and this reduction would increase the average annual productivity growth rate by 0.08 percentage points more in an industry at the $75^{\text {th }}$ percentile of profitability than in an industry at the $25^{\text {th }}$ percentile of profitability.

[Table 10. Estimated effects of corporate taxes on TFP: Industry-level]

The effect of tax incentives for R\&D spending is obtained by using the B-index ${ }^{3}$ as a proxy of the generosity of R\&D tax incentives. The main result is:

R\&D tax incentives are estimated to raise R\&D spending (Table 10, Column 2). However, the average effect of tax incentives on the level of TFP is rather small, though it appears to be larger in R\&D intensive industries. A simulation experiment indicates that the effect on the annual TFP growth rate of an increase of the tax incentives from $10 \%$ to $15 \%$ (equivalent to a 5 cents increase in tax subsidy per dollar invested in R\&D) would be 0.01 percentage points larger for an industry having the median R\&D intensity than for an industry with the lowest level of R\&D intensity. Again, this may be interpreted as a median effect if it is assumed that the effect of tax subsidies is close to zero in industries with very low R\&D intensity. The effect of R\&D incentives could potentially be larger in R\&D intensive industries. Indeed, this increase in tax incentives is estimated to raise the average annual productivity growth rate by 0.09 percentage points more in an industry at the 75th percentile of the distribution of R\&D intensity than in a sector at the 25th percentile of R\&D intensity.

1. For example, some industries may tend to be more profitable not because of pure economic rents, but because they rely on high expected returns to capital to compensate for high-risk investment projects such as R\&D or other intangible factors.

2. It is important to remember that this estimation approach only captures the effect of a tax working through a specific channel, here through industry's profitability and R\&D intensity. Any direct effect of the specific tax on TFP (unrelated to the industry characteristics) is captured in the fixed effects.

3. The B-index measures the minimum value of before-tax income that a firm needs to cover the cost of R\&D investment where the cost is standardised to one dollar. R\&D tax incentives are measured as one minus the B-index.

84. Effective corporate tax rates are broader measures of the corporate tax burden than statutory corporate tax rates since they take into account both the rate at which corporate profits are taxed and the tax base to which it is applied. They may, therefore, capture additional channels through which corporate taxation affect TFP (Box 10). Indeed, the empirical results assessing the effect of the effective corporate 
tax rate on TFP using industry-level data suggest that high average effective corporate taxes have a negative impact on TFP.

\section{Box 10. Effect of effective corporate tax rates on TFP}

Effective tax rates are derived from theoretical investment models where firms maximise the after-tax net present value (NPV) of their investment projects given the tax system. Depending on the assumptions of the model the effective rates can refer to a marginal effective tax rate (METR) which is applied to incremental investment projects earning just their minimum required return or to an average effective tax rate (AETR) which is applied to discrete investment projects earning some economic rent. The empirical analysis in this study uses data on the effective tax rates computed by the Institute for Fiscal Studies (IFS) based on the methodology of Devereux and Griffith (2003). The focus is on two important elements of corporate tax codes: the depreciation allowances and statutory corporate tax rates. ${ }^{1}$ Depreciation allowances are deducted from firms' taxable income and thus they reduce the cost of investment.

The empirical results using industry-level data on a panel of 12 OECD countries covering 21 industries over the 1981-2001 period suggest that the average effective corporate tax (AETR) has a negative effect on TFP. As pointed out in Box 4 and Box 9, the estimated effects are significant and give qualitative information about the sign of the effect of effective taxes on TFP, but the size of the effects is somewhat larger than expected. A simulation experiment indicates that the effect of a reduction of the effective tax rate from $35 \%$ to $30 \%$ on the average yearly TFP growth rate (over 10 years) would be 0.1 percentage points larger for an industry with the median profitability than for an industry with the lowest level of profitability. As discussed in Box 9, this may be interpreted as a median effect. The effect of this tax cut on TFP depends on the industry structure and this reduction would increase the average annual productivity growth rate by 0.1 percentage points more in an industry at the 75th percentile of profitability than in an industry at the 25th percentile of the distribution of profitability (see Vartia, 2008 for details).

1. Thus, the rates ignore, for example, the personal taxes paid by the shareholders.

Targeted corporate rates: the dispersion of effective rates can also adversely affect TFP

85. While the statutory corporate tax rate applies mostly to large corporations, some firms are taxed with lower targeted corporate tax rates. These rates are intended to lessen the impact of corporate tax rates on investment of certain types of firms (mainly small- and medium-sized firms) or regions. As illustrated in the previous section, about half of OECD countries have some form of reduced corporate tax rates targeted at either small firms, certain business activities or firms operating in certain regions. The standard justification for differential tax treatment of small firms is that they could suffer from market failures. ${ }^{29}$ However, this rationale is not always uncontentious, the targeting may be difficult to achieve and the implied tax relief may involve a waste of funds. ${ }^{30}$ Also, this special tax relief may result in an economic inefficiency if, as a consequence, resources are allocated towards small, less productive firms, due for instance to threshold effects (Crawford and Freedman, 2007). It can also lead to the artificial splitting of firms to obtain the preferential rate. The unintended result could be to prevent some firms to grow to their optimal scale of production, with negative consequences on productivity performance.

29 For example, these market failures could be asymmetric information on market or products, monopoly power of large firms making entry difficult for small firms or difficulties for small firms in raising finance (Crawford and Freedman, 2007).

30 Similar conclusions are reached in International Tax Dialogue (2007). 


\section{Tax incentives have some effects on productivity through $R \& D$}

86. As already mentioned, corporate taxes can have a negative effect on investment in $R \& D$, and thus TFP, in a similar way as taxes affect physical investment. But, other factors beyond taxation, such as market failures, may reduce private incentives for firms to invest in innovation, possibly preventing private investment from reaching socially optimal levels. ${ }^{31}$ To counteract these possible market failures, many OECD countries grant some type of $R \& D$ tax incentives in order to stimulate private-sector innovative activity. A recent OECD study found that tax incentives could help to raise R\&D expenditure and innovative activity, but with long time lags and a relatively modest overall impact (Jaumotte and Pain $2005 \mathrm{a}, \mathrm{b}$ ). Further, these tax incentives were found to have stronger effects on both R\&D expenditure and patents than direct funding. These findings partly confirm earlier OECD work on the impact of public expenditure on R\&D (Guellec and van Pottelberghe, 2000).

87. One advantage of R\&D tax incentives, compared to other more direct forms of support for innovative activity, is that decisions on which $R \& D$ projects to undertake are taken by firms themselves and so are more likely to be successful than projects selected by government officials. At the same time, the deadweight losses may be larger for general tax incentives than for targeted direct grants. Moreover, tax incentives, like direct subsidies, are generally only available for formal $R \& D$, which is mainly implemented in manufacturing industries. Tax incentives to raise R\&D may, therefore, have little effect on productivity in the increasingly important service sectors, where innovations are often produced informally in the course of ordinary business operations. Additionally, the increasingly footloose nature of investment suggests that R\&D spending in one country is also likely to respond to a change in incentives in other countries (Abramovsky, et al. 2005). Thus, if tax incentives that attract R\&D activities of multinationals in one country are matched by similar benefits offered by other countries, the overall loss of tax revenue may exceed the benefits to be obtained locally from $R \& D$ externalities or knowledge spill-overs from MNEs.

88. Empirical results using industry-level data support previous findings in that tax incentives for R\&D appear to enhance TFP (Box 9 for details). But, the effect of tax incentives on the level of TFP relative to best practice level seems to be rather small. For example, a five percentage points increase in these incentives (equivalent to an increase of the subsidy by 5 cents per dollar spent on R\&D) would raise the yearly TFP growth rate in an industry with median R\&D intensity by 0.01 percentage points more than in an industry with very low R\&D intensity (see Box 9). ${ }^{32}$ This corroborates the conclusion of Jaumotte and Pain, $(2005 a, b)$ that tax policies can do relatively little to enhance innovative activity. ${ }^{33}$ However, the analysis also shows that the effect of R\&D incentives could potentially be larger in $R \& D$ intensive industries and, to the extent that tax-induced innovative activities in highly R\&D intensive industries may translate in a persistent acceleration of TFP growth, tax reforms that enhance R\&D spending may still be beneficial. In any event, conclusions about the advantage of these tax incentives over general cuts in corporate taxation for R\&D outcomes should be based on the relative cost-effectiveness of these policies, which is an area that needs further investigation.

31 Firms face difficulties in appropriating the benefits of their investments in innovation while preventing their competitors from doing so. The extent to which this is possible depends on both the strength of competition and the degree of protection of intellectual property rights

32 This increase corresponds to $1 / 2$ of the standard deviation of tax subsidies across countries.

33 This may suggest that non-tax policies should be considered in addressing under investment in R\&D and low total factor productivity in OECD countries, such as reforms in product markets, tertiary education and research policies and intellectual property rights regimes. 


\section{Effective cross-border tax rates may also affect the international allocation of fixed capital}

89. Taxes influence investment incentives of foreign investors in a similar way as those of domestic investors. Aside from the effects of tax wedges on labour (see above), tax influences on FDI include both domestic tax rates and other tax arrangements affecting cross-border incomes. A country's attractiveness as a location for foreign direct investment (FDI) depends, among other things, on how its tax system compares with possible competitor destinations. The combined effect of the home and the host country's tax codes as well as bilateral and multilateral tax agreements matter, for example, withholding taxes that countries apply to payments abroad from firms operating in the domestic economy may depend on tax treaties (see e.g. Yoo, 2003).

90. The implications of FDI taxation regimes are likely to be different from those of taxation on domestic investment because FDI not only adds to capital formation but also generates technology and knowledge spillovers that can boost productivity of domestic firms (Keller 2004; Griffith et al. 2004; Criscuolo, 2006; Bloom et al. 2007). Furthermore, foreign affiliates may increase the level of competition and thus the incentives to improve productivity in the host country. Some non-policy factors also affect how FDI responds to changes in different taxes. In particular, FDI may be more sensitive to taxes in small countries (or countries having a small market size) or in countries facing comparative disadvantages related to distance or transaction costs. Recent empirical OECD work found evidence of an adverse effect of corporate taxes on FDI, however, the effect seems to be small relative to that of tax wedges on labour income and other policies affecting the business environment (Hajkova et al. 2006). ${ }^{34}$ This result is consistent with the conclusions in an OECD literature review which finds considerable evidence of a negative relationship between FDI and host country taxation (OECD, 2007c).

91. Foreign direct investment allows firms to choose their location based inter alia on taxes. In turn, this can spur tax competition in order to attract both foreign affiliates and profits generated by activities elsewhere, which multi-national enterprises can shift to relatively low tax countries (see below). There is some evidence that multinational firms react to tax incentives (for overviews see Gordon and Hines 2002 and OECD, 2007c) and of tax competition taking place in recent years resulting in cuts in the corporate tax rates (see e.g. Devereux and Sorensen, 2006). The ongoing integration of world capital markets and the increase in the mobility of capital has affected the sensitivity of the capital base to tax changes. This can spur further tax competition and have important implications for the design and effect of tax policies.

92. A further factor that can influence the international allocation of fixed capital is whether the home country of a multinational firm exempts foreign dividends from tax, or subjects them to domestic taxation while providing a credit for taxes already paid in the source country. The economic rationale for the credit system is that, in principle, it removes any corporate tax distortion between domestic and foreign investment by domestically owned firms, and between investments in different foreign countries (i.e. it furthers "capital export neutrality"). However, the credit system is never implemented in a way that fully achieves this: countries normally limit the credit to the amount of tax that would have been due under domestic law, and most countries grant deferral to 'active' business income so that it is only taxed when it is repatriated. In contrast, the economic rationale for the exemption system is that, if all countries adopted it, investments into a particular country would all be taxed the same, regardless of their country of origin (i.e. "capital import neutrality"). This promotes equal competition within any host country and also means that the transfer of ownership of a company from one multinational group to another would not affect the corporate taxes levied on its profits (thus facilitating the transfer of companies to the owners that will manage them most efficiently). However, as with the credit system, most countries do not employ a 'pure' exemption system, applying the credit system in certain situations. Over the past 15 years, there has been a

34 The study shows that a one percentage point increase in the effective corporate tax rate of the host country reduces its FDI stocks by $1 \%$ to $2 \%$. 
gradual movement of countries moving from a credit to an exemption system, at least in part because of the competitive edge that this can give to their resident multinational firms.

\section{Issues in the design of a growth-oriented corporate income tax system}

93. Summing up, the main reason for imposing a corporate income tax is that the tax plays an important withholding function, acting as a "backstop" to the personal income tax (for an overview see OECD, 2007b). In the absence of corporate income taxation, business earnings that are retained escape taxation until the shareholder realises the corresponding capital gains or losses. And in the absence of capital gains tax, retained earnings would not be taxed at all. Therefore, by levying corporate income tax governments prevent shareholders from sheltering their equity income from taxation and, at the same time, avoid large differences in the tax burdens on capital versus labour income and on corporate versus unincorporated businesses.

94. There is a wide consensus that corporate taxation should avoid discouraging efficiency improvements and aim at ensuring neutrality and consistency, for instance, by not favouring some investment or firms at the expense of other, potentially more productive, investment or firms (e.g. Devereux and Sørensen, 2006). This would imply a reasonably low corporate tax rate with few exemptions. As described earlier, recently most tax reforms in the OECD have indeed involved tax cuts and base broadening $(\mathrm{OECD}, 2007 \mathrm{~b}){ }^{35}$ This approach minimises tax-induced distortions while raising revenues as efficiently as possible.

95. Besides the level of the corporate rate and the breadth of the tax base, the following areas could also be considered:

- Exemptions. The evidence reviewed and the empirical results in this section suggest that preferential tax treatment of or exemptions from corporate taxation for small firms are not likely to be justified. Investment decisions of small firms do not appear to be more sensitive to corporate taxes than those of large firms - indeed evidence points to the opposite. Moreover, TFP in small firms tends to be less sensitive to corporate taxation than TFP in other types of firms. Thus, special tax reliefs based on firm size could result in economic inefficiencies as resources may be wasted. Cutting back on these exemptions free resources for cuts in the overall statutory corporate tax rate, which were found to be beneficial for enhancing economic growth by favouring high return and rapidly catching up firms and industries.

- Tax incentives for innovation. Tax incentives for R\&D to stimulate private-sector innovative activity seem to have larger effects than direct support, but these effects appear nonetheless relatively small outside R\&D intensive industries. Other measures, such as pro-competitive product market reforms or reforms in tertiary education systems, may be more effective for enhancing innovation activities.

- Double taxation of equity. The choice of treatment of corporate equity income can have implications for economic growth. In many countries corporate equity is taxed both at the company and at the shareholder level in form of dividend and capital gains tax. The treatment of such income at the personal level is important since this "double taxation" creates disincentives to invest and discriminates against equity finance in favour of debt and thereby tilts the playing field in the direction of enterprises that easily obtain debt finance. Particularly personal taxes on

35 The definition of the corporate tax base in OECD countries is complex as it involves legislation covering many areas such as allowances for capital expenditure, valuation of assets and to which extent expenses can be deducted. 
corporate equity income distort the cost of equity capital for small firms without access to international stock markets. It also discourages firms from choosing to become corporations. Generally, double taxation of dividends may inhibit firm growth, with negative consequences on economic performance.

- Relation with personal income taxation. The possibility of tax minimisation by shifting income between corporate and personal taxation needs to be taken into account when designing the corporate tax system. If personal income is taxed at a significantly higher rate than corporate income this may encourage an entrepreneur to classify her/his income as corporate instead of personal, which would reduce tax liabilities, consequently eroding the tax base and lowering overall tax revenues collected.

- Tax complexity. Another issue is that the increasing complexity of the tax system may be harmful for growth. Complex tax codes tend to result in high tax compliance costs than can lead to a loss of efficiency as resources are wasted to comply with the tax system instead of being put into productive use. It may also contribute to make the business environment less friendly, deterring FDI. A complex tax system also contributes to low awareness of incentives and tax reliefs, especially among small firms, which may reduce investment and economic performance. One reason for the increasing complexity of the tax system is that governments react to tax planning by some firms with anti-abuse legislation that inevitably increases the administrative load on all firms. For instance, Slemrod et al. (2007) suggest that tax complexity in the United Kingdom has increased in recent years mainly because a significant volume of anti-avoidance legislation has been added to the tax code. However, measuring the complexity of the tax system is not easy and no representative cross-country tax indicator has been developed in this field. Even though there is yet no available cross-country evidence on the growth effects of tax complexity, a cautious approach in the design of corporate taxation is to aim for a simple tax system.

- International aspects. It is not necessarily the case that a high tax rate produces high tax revenues since, with open economies, firms can choose to locate their activities, or their profits, in low-tax countries. The possibility of shifting incomes between different jurisdictions has become more important with globalisation. Multinational firms who are active in many countries may be able to shift profits between countries by using transfer pricing and intra-group loans to take advantage of lower levels of corporate statutory tax rates. ${ }^{36}$ Thus, countries may seek to compete over mobile capital and the corporate tax base by lowering effective and statutory tax rates. The empirical literature on tax competition suggests that the increasing mobility of capital has had some impact on lowering corporate statutory tax rates, which is consistent with the observed reductions in the statutory rates in OECD countries over the last two decades. The physical location decision of multinationals (MNEs) is important since they may contribute to the host country's growth by spurring competition and facilitating the transfer of new technologies adding to productivity growth. But it has to be recognised that tax is only one factor in influencing these decisions. subsidiaries abroad. The OECD transfer pricing guidelines maintain the arm's length principle of treating related enterprises within a multinational group and affirm traditional transaction methods as the preferred way of implementing the principle (OECD 1995). The "Arms Length Price" represents the price charged in comparable transactions between independent parties, where the price is not influenced by the relationship or business interest between the parties in the transaction. 


\section{The overall tax design}

\subsection{Bringing together individual tax effects}

96. The "bottom-up" approach adopted in the previous section gives a detailed description of the main growth linkages concerning each type of tax. But these separate effects need to be brought together in order to understand the overall impact of tax systems on economic performance. This section proposes a simple framework for attempting such a synthesis. In this framework, taxes are organised in an overview matrix (Figure 14) in four broad groups: consumption, property, personal income and corporate income tax. Within this broad tax mix, the differential impact of individual tax instruments on the drivers of GDP per capita is reported relying on the links highlighted in the previous section. Each entry in the matrix considers the impact of an increase in one tax, holding all other taxes unchanged, on a performance measure. A negative (positive) sign indicates that an increase in the tax adversely (positively) affects the driver of growth. However, some taxes may simultaneously influence, possibly in different ways, many drivers of growth. Reading down the rows in the matrix it is possible to consider the effect of a tax measure, for example the average personal income tax wedge, on all the determinants of growth. Similarly, looking across the columns in the matrix allows assessing the effect of all taxes on one of the drivers of growth. A memorandum item indicates if strong distributional effects arise from changes in those taxes. The last column compares performance in each of the drivers of GDP per capita relative to average OECD performance.

\section{[Figure 14. Tax matrix]}

97. The advantage with this set-up is that it can account for reinforcing or offsetting effects on overall economic performance of tax reforms involving the adjustment of several tax instruments. The level and design of taxes in a country relative to a benchmark (a country or OECD average) could be compared with the relative performance of the country on each of the drivers of growth that are affected by these taxes. Thus, it could be of some use in the annual "Going-for-Growth" exercise for identifying tax policy priorities in OECD countries. Clearly, the matrix by itself cannot provide policy guidance since, as explained in previous sections, additional country-specific factors must be taken into account in the design of tax reforms. These include the starting level of taxation and tax mix, interactions with country-specific policy and institutional settings in other areas (such as bargaining and other labour market features), the effectiveness of tax administration and so on. The next paragraphs provide an attempt to account for such complexities within a broad framework for tax policy design.

\section{Broad tax design: policy insights from the previous sections}

98. All OECD countries rely on a mix of consumption, property, personal income, and corporate income tax. The evidence reviewed in the previous sections indicate that setting the right mix is important, because the distortionary effects of collecting revenue from different sources can be very different and there could be efficiency gains from replacing part of the revenues from income taxes with revenues from less distortionary taxes such as consumption or property taxes, especially recurrent taxes on residential property, for a given overall level of the tax burden (e.g. Dahlby 2003; European Commission, 2006). The empirical work undertaken for this project confirms this conjecture and, abstracting from other policy objectives, suggests a "tax and growth ranking" of the tax instruments with regard to their long-run effect on GDP per capita (see Box 11 for details).

99. The following results are worth mentioning:

- Taxing consumption and property appears to have significantly less adverse effects on GDP than taxing income. 
- Corporate income taxes appear to have a particularly negative impact on GDP per capita. This is consistent with the previously reviewed evidence and empirical findings that lowering corporate taxes raises TFP growth and investment. Reducing the corporate tax rate also appears to be particularly beneficial for TFP growth of the most dynamic and innovative firms. Thus, it seems that corporate taxation affects performance particularly in industries and firms that are likely to add to growth. The adverse influence of corporate taxes on GDP per capita through TFP is also consistent with the additional linkages described in Figure 14, including those working through entrepreneurship, innovative activity and FDI.

- As discussed earlier and illustrated in Figure 14, the distortionary effects of property taxes on the allocation of resources in the economy are likely to be less severe than those of income and consumption taxes. Indeed, within non-income taxation, recurrent taxes on immovable property seem to have the least adverse effect on GDP per capita. ${ }^{37}$

\begin{abstract}
Box 11. Empirical findings on the aggregate effects of the tax structure on GDP
The empirical findings at the macro level on the effect of the tax structure on long-run GDP were obtained by introducing a set of tax structure indicators into a panel regression of GDP per capita covering 21 OECD countries over the period 1970 to 2005 (for details see Arnold, 2008). Throughout the analysis, differences across countries in the overall tax burden are accounted for by including the level of the tax-to-GDP ratio. The setup also considers the government budget constraint and takes into account that more use of a given tax instrument reduces the amount of revenues that need to be raised from other taxes. ${ }^{1}$ This allows drawing conclusions on the impact of a revenue-neutral shift from one tax instrument to another on longrun GDP. The main findings reported in Table 11 are:

Estimates of the effect on GDP per capita of changing the tax mix while keeping the overall tax-to-GDP ratio constant indicate that a shift of $1 \%$ of tax revenues from income taxes to consumption and property taxes would increase GDP per capita by between a quarter of a percentage point and one percentage point in the long run depending on the empirical specification. The magnitude of the estimated effect is larger than what would be reasonably expected. Given that there is a wide dispersion of the point estimates across specifications it is clear that the size of the effects cannot be measured precisely in a cross-country comparative setting. For example, the estimated effects may overstate the effect of a shift in the tax mix because this shift may trigger similar shifts in the trading partners' economies, which would reduce the benefits from such a shift in the home country. Thus, the magnitude of the effects should be interpreted with caution. Column 1 shows a negative growth impact for a move from consumption and property taxes to income taxes, while Column 3 estimates a similarly-sized positive effect for an opposite shift away from income taxes.

Column 2 reports results in which a decrease in corporate income taxes (financed by an increase in consumption and property taxes) has a stronger positive effect on GDP per capita than a similar decrease in personal income taxation.

Results reported in Column 4 break up the effect of an increase in consumption and property taxes, allowing a reduction in income taxation. While both of them are associated with higher GDP per capita than relying on income taxes, the effect is significantly larger for property taxes. Column 5 separates recurrent taxes on immovable property from all other property taxes and the positive effect on GDP is significant larger for recurrent taxes on immovable property than for all other property taxes and consumption taxes.
\end{abstract}

\title{
[Table 11. Estimated cross-country effects of the tax mix on long-run GDP per capita]
}

The qualitative empirical findings are robust to a large number of robustness checks and alternative specifications, including the addition of several other economic variables affecting long-run GDP. In contrast, the magnitudes of the estimated effects are sensitive to the exact empirical specification, including the number of other economic and policy variables accounted for in the analysis. Moreover, the results obtained need to be interpreted with some caution as it is possible that the overall tax burden and the revenues shares are not independent of each other in the data, possibly leading estimated coefficients to be biased in terms of the effects of revenue-neutral tax changes.

1. There is a possibility that the effects of certain taxes may be different in settings where this tax instrument is already heavily used. To take this into account, an alternative specification that allows for non-linearities in the effects of individual taxes by adding them as quadratic terms in addition to the linear specification has been tried. However, these estimations were not able to generate significant coefficient estimates. 
100. The evidence surveyed in this study and the empirical work suggests that there could be gains in terms of long-run GDP per capita from increasing the use of consumption and property taxes relative to income taxes without changing overall tax revenues. One recent example of such a tax shift is in Germany where the VAT rate was increased in the beginning of 2007 from $16 \%$ to $19 \%$, partly to finance a cut in social security contributions. However, it is likely that the response of the economy to such a revenue shift would vary across countries depending on the precise nature of the reform as well as country characteristics. For example, a shift away from personal income taxes towards consumption taxes can have potentially larger positive effects on GDP per capita if it takes the form of cuts in marginal personal income tax rates rather than increases in thresholds (although the latter would be more effective at reducing inequality). It is also possible that the effectiveness of such a tax shift would vary across countries depending on the efficiency in collecting VAT and consumption taxes (as indicated by the c-efficiency of VAT).

101. In the long-run a revenue-neutral shift from personal income to VAT/consumption taxes may not have much effect on the average total taxes paid by a typical employee and so is unlikely to affect their decisions as to whether or not to work. This is because a reduction in income taxes offset by an increase in VAT/consumption tax by the same amount does not affect the real net wage of workers and leaves labour supply unaffected. This is the case if labour supply depends on the total tax burden of a worker and VAT/consumption tax is largely paid by workers, in which case there is limited opportunity to affect labour supply through this reform (e.g. Layard et al. 1996). But since personal income taxes are generally more progressive than consumption taxes this reform will reduce the marginal tax rate of a typical worker and increase their incentive to work additional hours and thus promote economic growth although at the expense of making the tax system less progressive. Also, if the increase in VAT/consumption taxes reduces the real income of those outside the labour force, it could increase the incentive to work.

102. If a shift from income to consumption taxation changes the incidence of taxation on different categories of workers, labour market institutions could also play a role in determining the effect of the change in tax policy on labour utilisation. For instance, the tax burden may be shifted to low-paid workers affecting their labour supply decision if they spend relatively more of their income on consumption goods that have experienced an increase in the price because of the tax increase. Likewise, the tax burden may also be shifted on to pensioners and other groups outside the labour market to the extent that their income follows gross wages. To the extent that wage-setting mechanisms, such as minimum wages, prevent the pass through of such additional tax burden on to wages, labour demand could be affected as well.

103. A reform towards greater use of taxes on consumption could raise GDP but it would also increase inequality, particularly at the lower end of the wage distribution as consumption taxes are less progressive than personal income taxes. This implies a trade-off between tax policies that enhance GDP per capita and equity. However, changes in the tax and benefits system could be used to offset some of the effects of this reform on inequality, although such changes would reduce work incentives and so offset (part or all of) the growth-enhancing effects of the tax shift. Some countries use reduced VAT rates on certain goods (e.g. food items) to lower the tax burden on low-income households, but this is a relatively ineffective way of reducing inequality. As discussed in Section 3.1, it is better to use the benefit system to deal with distributional concerns. Even so, it is possible that a large group of voters could lose out from a shift to consumption taxes, making it politically and socially difficult to implement. The redistributive implications of the tax shift may also have adverse effect on the labour force participation of marginal workers (European Commission, 2006). This may happen because, as wages and personal income taxes of lowskilled workers are already low, they would gain little from a cut in personal income taxes, but would lose from the increase in consumption taxes, reducing their likelihood of labour force participation. 
104. A shift towards taxes on property appears to be even better for growth than a shift towards consumption taxes and has the added advantage that it would be less likely to raise equity concerns. The discussion in Section 3.2 suggests that the best form of the shift would be towards recurrent taxes on immovable property as this is the least distortionary type of property tax. Nonetheless, there are two practical drawbacks to a significant shift towards greater taxation of immovable property. First, these taxes are very unpopular in many countries, at least in part because of their visibility. This unpopularity could be reduced if the reforms suggested in Section 3.2 were implemented, especially the use of up-to-date valuations and provisions to deal with the situation of people with low incomes and illiquid assets. In some countries, an increase in the progressivity of the tax might make it more acceptable. The second practical drawback is that, in most OECD countries, property tax revenues belong to local governments and so a shift towards property taxes would require some changes to the revenue sharing arrangements. However, this difficulty should not be over-estimated as in most OECD countries local governments receive some income tax revenues (which could be substituted by property tax revenues) and/or substantial grants from higher levels of governments (which could be reduced as property tax revenues increased). 


\section{ANNEX 1: TABLES AND FIGURES}

\section{Tables}

1. Revenue shares of the major taxes in the OECD area

2. The evolution of standard value-added tax rates

3. Taxation of residential property (2002)

4. Taxes on capital income taxation at the household level in selected OECD countries (2004/2005)

5. Standard and reduced (targeted) corporate income tax rates for small businesses (2005)

6. $\quad$ Estimated effects of labour taxes on TFP: industry-level

7. Estimated effects of corporate taxes on investment: firm-level

8. Estimated effects of corporate taxes on investment: industry-level

9. Estimated effects of corporate taxes on TFP: firm-level

10. Estimated effects of corporate taxes on TFP: industry-level

11. Estimated cross-country effects of the tax mix on long-run GDP per capita

\section{Figures}

1. Tax-to-GDP ratios in the OECD area (1975-2006)

2. Tax structures in the OECD, 1985 and 2005 (selected countries/areas)

3. Revenues from environmentally-related taxes in per cent of GDP

4. The evolution of property taxes (as a percentage of GDP)

5. Top statutory personal income tax rates on wage income

6. Average income tax for a single individual at average earnings

7. Statutory income tax progressivity for single individuals at average earnings

8 Tax wedge for single individual at average earnings

9. Statutory corporate income tax rates

10. Overall statutory tax rates on dividend income (2000 and 2007)

11. Tax subsidies for one US\$ of research and development in OECD countries (2007)

12. Taxes affect the determinants of growth

13. C-efficiency for VAT (average 2002-2004)

14. Tax matrix 
Table 1. Revenue shares of the major taxes in the OECD area

\begin{tabular}{lrrrrrrr}
\hline & 1975 & 1980 & 1985 & 1990 & 1995 & 2000 & 2005 \\
\cline { 2 - 7 } & & & & & & & \\
Personal income tax & 30 & 31 & 30 & 30 & 27 & 26 & 25 \\
Corporate income tax & 8 & 8 & 8 & 8 & 8 & 10 & 10 \\
Social security contributions & 22 & 22 & 22 & 22 & 25 & 24 & 26 \\
$\quad$ (employee) & $(7)$ & $(7)$ & $(7)$ & $(8)$ & $(8)$ & $(8)$ & $(8)$ \\
$\quad$ (employer) & $(14)$ & $(14)$ & $(13)$ & $(13)$ & $(14)$ & $(14)$ & $(15)$ \\
Payroll taxes & 1 & 1 & 1 & 1 & 1 & 1 & 1 \\
Property taxes & 6 & 5 & 5 & 6 & 6 & 5 & 6 \\
General consumption taxes & 15 & 15 & 16 & 17 & 18 & 18 & 19 \\
Specific consumption taxes & 18 & 17 & 16 & 13 & 13 & 12 & 11 \\
Other taxes 2 & 1 & 0 & 1 & 3 & 3 & 3 \\
Total & 100 & 100 & 100 & 100 & 100 & 100 & 100 \\
\hline
\end{tabular}

1. Including social security contributions paid by the self-employed and benefit recipients (heading 2300) that are not shown in the breakdown over employees and employers.

2. Including certain taxes on goods and services (heading 5200) and stamp taxes.

Source : OECD Revenue Statistics 
Table 2. The evolution of standard value-added tax rates

Percent

\begin{tabular}{|c|c|c|c|c|c|c|c|c|}
\hline & 1975 & 1980 & 1985 & 1990 & 1995 & 2000 & 2005 & 2007 \\
\hline Australia & - & - & - & - & - & 10 & 10 & 10 \\
\hline Austria & 16 & 18 & 20 & 20 & 20 & 20 & 20 & 20 \\
\hline Belgium & 18 & 16 & 19 & 19 & 20.5 & 21 & 21 & 21 \\
\hline Canada & - & - & - & - & 7 & 7 & 7 & 6 \\
\hline Czech Republic & - & - & - & - & 22 & 22 & 19 & 19 \\
\hline Denmark & 15 & 22 & 22 & 22 & 25 & 25 & 25 & 25 \\
\hline Finland & - & - & - & - & 22 & 22 & 22 & 22 \\
\hline France & 20 & 17.6 & 18.6 & 18.6 & 20.6 & 20.6 & 19.6 & 19.6 \\
\hline Germany & 11 & 13 & 14 & 14 & 15 & 16 & 16 & 19 \\
\hline Greece & - & - & - & 18 & 18 & 18 & 19 & 19 \\
\hline Hungary & - & - & - & 25 & 25 & 25 & 20 & 20 \\
\hline Iceland & - & - & - & 22 & 24.5 & 24.5 & 24.5 & 24.5 \\
\hline Ireland & 19.5 & 25 & 23 & 23 & 21 & 21 & 21 & 21 \\
\hline Italy & 12 & 15 & 18 & 19 & 19 & 20 & 20 & 20 \\
\hline Japan & - & - & - & 3 & 3 & 5 & 5 & 5 \\
\hline Korea & - & 10 & 10 & 10 & 10 & 10 & 10 & 10 \\
\hline Luxembourg & 10 & 10 & 12 & 12 & 15 & 15 & 15 & 15 \\
\hline Mexico & - & 10 & 15 & 15 & & 15 & 15 & 15 \\
\hline Netherlands & 16 & 18 & 19 & 18.5 & 17.5 & 17.5 & 19 & 19 \\
\hline New Zealand & - & - & - & 12.5 & 12.5 & 12.5 & 12.5 & 12.5 \\
\hline Norway & & 20 & 20 & 20 & & 23 & 25 & 25 \\
\hline Poland & - & - & - & - & 22 & 22 & 22 & 22 \\
\hline Portugal & - & - & - & 17 & 17 & 17 & 21 & 21 \\
\hline Slovak Republic & - & - & - & - & 23 & 23 & 19 & 19 \\
\hline Spain & - & - & - & 12 & 16 & 16 & 16 & 16 \\
\hline Sweden & 17.65 & 20.63 & 23.46 & 23.46 & 25 & 25 & 25 & 25 \\
\hline Switzerland & - & - & - & - & 6.5 & 7.5 & 7.6 & 7.6 \\
\hline Turkey & - & - & & 10 & 15 & 17 & 18 & 18 \\
\hline United Kingdom & 8 & 15 & 15 & 15 & 17.5 & 17.5 & 17.5 & 17.5 \\
\hline United States & - & - & - & - & - & - & - & - \\
\hline
\end{tabular}

Source : OECD Revenue Statistics 
Table 3. Taxation of residential property (2002)

\begin{tabular}{|c|c|c|c|c|c|}
\hline & \multirow{2}{*}{$\begin{array}{l}\text { Imputed } \\
\text { rental } \\
\text { income } \\
\text { taxed }\end{array}$} & \multicolumn{2}{|c|}{ Tax relief on mortgages } & \multirow{2}{*}{$\begin{array}{c}\text { Capital gains on } \\
\text { housing assets } \\
\text { taxable }\end{array}$} & \multirow{2}{*}{$\begin{array}{c}\text { Estate/ } \\
\text { Gift/Inheritance } \\
\text { tax }\end{array}$} \\
\hline & & Interest & $\begin{array}{l}\text { Principal } \\
\text { repayments }\end{array}$ & & \\
\hline Austria & $\mathrm{N}$ & $\begin{array}{c}\mathrm{Y} \\
\text { (up to ceiling) }\end{array}$ & $\mathrm{N}$ & Y & Y \\
\hline Belgium & $\begin{array}{c}\text { Y } \\
\text { (with fixed } \\
\text { deduction) }\end{array}$ & $\begin{array}{l}\text { Y } \\
\text { (up to imputed } \\
\text { rental income) }\end{array}$ & $\begin{array}{c}\mathrm{Y} \\
\text { (within limit) }\end{array}$ & $\begin{array}{c}\mathrm{Y} \\
\text { (if sold }<5 \text { years) } \\
\text { POOD are exempt }\end{array}$ & $\mathrm{Y}$ \\
\hline Canada & $\mathrm{N}$ & $\mathrm{N}$ & $\mathrm{N}$ & $\begin{array}{c}\mathrm{Y} \\
\text { (on 50\% of gains) } \\
\text { POOD are exempt }\end{array}$ & $\begin{array}{c}\mathrm{N} \\
\text { (but subject to } \\
\text { capital gains tax } \\
\text { from which POOD } \\
\text { are exempt) }\end{array}$ \\
\hline Denmark & $\mathrm{N}$ & $\mathrm{Y}$ & n.a. & $\begin{array}{c}\mathrm{Y} \\
\text { POOD are exempt }\end{array}$ & Y \\
\hline Germany & $\mathrm{N}$ & $\mathrm{N}$ & $\mathrm{N}$ & $\begin{array}{c}\mathrm{Y} \\
\text { (if sold }<10 \text { years) } \\
\text { POOD are exempt }\end{array}$ & $\begin{array}{c}Y \\
\text { (lower than for } \\
\text { financial assets) }\end{array}$ \\
\hline Finland & $\mathrm{N}$ & $\begin{array}{c}\mathrm{Y} \\
\text { (up to a } \\
\text { ceiling) }\end{array}$ & n.a. & $\begin{array}{c}\text { Y } \\
\text { POOD exempt if } \\
\text { sold > } 2 \text { years }\end{array}$ & Y \\
\hline France & $\mathrm{N}$ & $\mathrm{N}$ & $\mathrm{N}$ & $\begin{array}{c}\mathrm{Y} \\
\text { POOD are exempt }\end{array}$ & Y \\
\hline Ireland & $\mathrm{N}$ & $\mathrm{Y}$ & $\mathrm{N}$ & $\begin{array}{c}\mathrm{Y} \\
\text { POOD are exempt }\end{array}$ & Y \\
\hline Italy & $\stackrel{N}{N}$ & $\begin{array}{c}\mathrm{Y} \\
\text { (for POOD) }\end{array}$ & $\mathrm{N}$ & $\begin{array}{c}Y \\
(50 \% \text { for POOD) }\end{array}$ & Y (until 2001) \\
\hline Netherlands & $\mathrm{Y}$ & Y & $\mathrm{N}$ & $\mathrm{N}$ & $\begin{array}{c}Y \\
\text { (above tax free } \\
\text { threshold) }\end{array}$ \\
\hline Norway & $\mathrm{Y}$ & Y & $\mathrm{N}$ & $\begin{array}{c}Y \\
\text { (exempt if } \\
\text { occupied by owner } \\
>1 \text { of } 2 \text { years } \\
\text { preceding sale) }\end{array}$ & $\mathrm{Y}$ \\
\hline Spain & $\begin{array}{c}\mathrm{N} \\
\text { (for POOD) }\end{array}$ & Y & $\mathrm{Y}$ & $\begin{array}{c}\text { Y } \\
\text { (exempt if } \\
\text { reinvested) }\end{array}$ & Y \\
\hline Sweden & Y & Y & $\mathrm{N}$ & $\begin{array}{c}\text { Y } \\
\text { (exempt if } \\
\text { reinvested) }\end{array}$ & $\mathrm{N}$ \\
\hline United Kingdom & $\mathrm{N}$ & $\mathrm{N}$ & $\mathrm{N}$ & $\begin{array}{c}\mathrm{Y} \\
\text { POOD are exempt }\end{array}$ & $\mathrm{Y}$ \\
\hline United States & $\mathrm{N}$ & $\begin{array}{c}\mathrm{Y} \\
\text { (up to ceiling) }\end{array}$ & $\mathrm{N}$ & $\begin{array}{l}\text { Y (until 2002) } \\
\text { (deduction for } \\
\text { POOD if held > } \\
2 \text { years) }\end{array}$ & $\mathrm{Y}$ \\
\hline
\end{tabular}

Note: POOD = principal owner-occupied dwellings.

Source: Catte, P., N. Girouard, R. Price, and C. André (2004), "Housing Markets, Wealth and the Business Cycle", OECD Economics Department Working Papers, No. 394; Baunkjoer, C.F. (2004), "Housing Taxation", Housing and Housing Policy in Nordic Countries, M. Lujanen (ed.), Nordic Council of Ministers. 
Table 4. Taxes on capital income at the household level in selected OECD countries (2004/2005)

\begin{tabular}{|c|c|c|c|c|}
\hline & $\begin{array}{l}\text { Dividend tax treatment } \\
\text { at the shareholder level } \\
(2005)\end{array}$ & $\begin{array}{l}\text { Tax treatment of capital } \\
\text { gains on portfolio equity } \\
\text { shares } \\
\text { (as of } 1 \mathrm{July,} \mathrm{2004)}\end{array}$ & $\begin{array}{l}\text { Tax treatment of } \\
\text { capital gains on } \\
\text { principal residence } \\
\text { (as of } 1 \mathrm{July,} 2004 \text { ) }\end{array}$ & $\begin{array}{l}\text { Taxation of } \\
\text { interest payments } \\
(2005)\end{array}$ \\
\hline Australia & $\begin{array}{l}\text { Dividends taxed at } \\
\text { marginal ordinary PIT } \\
\text { rates }(0 \%-17 \%-30 \%- \\
42 \%-47 \%) \text { but imputation } \\
\text { credit is provided for } \\
\text { corporate tax already paid } \\
\text { (full imputation system). }\end{array}$ & $\begin{array}{l}\text { Shares held }<1 \text { year: capital } \\
\text { gain included in assessable } \\
\text { income. } \\
\text { Shares held } \geq 1 \text { year: } 50 \% \\
\text { of capital gain included in } \\
\text { assessable income. Capital } \\
\text { gain taxed at marginal } \\
\text { ordinary PIT rates. }\end{array}$ & $\begin{array}{l}\text { Exempt (partial capital } \\
\text { gains inclusion to extent } \\
\text { used for business or } \\
\text { rent). }\end{array}$ & $\begin{array}{l}\text { Taxed at marginal } \\
\text { ordinary PIT rates } \\
(0 \%-17 \%-30 \%- \\
42 \%-47 \%)\end{array}$ \\
\hline Belgium & $\begin{array}{l}25 \% \text { flat rate in general; } \\
15 \% \text { flat rate under } \\
\text { certain conditions. }\end{array}$ & $\begin{array}{l}\text { Shares purchased with } \\
\text { speculative intent: } 33 \% \text { flat } \\
\text { rate. } \\
\text { Other shares: exempt. }\end{array}$ & $\begin{array}{l}\text { Exempt. If gains } \\
\text { deemed as speculative, } \\
\text { taxed at } 16.5 \% \text { flat rate. }\end{array}$ & $15 \%$ flat rate \\
\hline Canada & $\begin{array}{l}\text { Dividends taxed at } \\
\text { marginal ordinary PIT } \\
\text { rates (federal and } \\
\text { provincial) but } \\
\text { imputation credit is } \\
\text { provided for corporate tax } \\
\text { already paid (full } \\
\text { imputation system in } \\
\text { 2006) }\end{array}$ & $\begin{array}{l}\text { Half }(50 \%) \text { inclusion in net } \\
\text { taxable capital gains. Taxed } \\
\text { at marginal ordinary PIT } \\
\text { rates. }\end{array}$ & $\begin{array}{l}\text { Exempt. Recognition of } \\
\text { no more than } 1 \\
\text { principal residence per } \\
\text { family at any one time. }\end{array}$ & $\begin{array}{l}\text { Taxed at marginal } \\
\text { ordinary PIT rates. }\end{array}$ \\
\hline Finland & $\begin{array}{l}43 \% \text { of dividends from a } \\
\text { quoted company are } \\
\text { exempt, with the } \\
\text { remaining } 57 \% \text { being } \\
\text { taxed as the shareholder's } \\
\text { income from capital } \\
\text { (taxed at } 28 \% \text { rate). }\end{array}$ & $\begin{array}{l}\text { Inclusion in income from } \\
\text { capital, separate taxation at } \\
29 \% \text { flat rate }(28 \% \text { in } \\
2005) \text {. }\end{array}$ & $\begin{array}{l}\text { Exempt if owned and } \\
\text { permanently occupied } \\
\text { by taxpayer for } \geq 2 \\
\text { years prior to sale. } \\
\text { Otherwise: } 29 \% \text { flat tax } \\
\text { rate is levied ( } 28 \% \text { in } \\
2005) .\end{array}$ & $\begin{array}{l}\text { Taxed at flat rate of } \\
28 \% \text {. }\end{array}$ \\
\hline Germany & $\begin{array}{l}50 \% \text { of dividends are } \\
\text { exempt (half-income } \\
\text { system). Other } 50 \% \text { are } \\
\text { taxed at ordinary } \\
\text { progressive PIT rates. }\end{array}$ & $\begin{array}{l}\text { Shares held } \leq 1 \text { year: half of } \\
\text { the profit is tax-exempt, } \\
\text { other half is taxed at } \\
\text { ordinary progressive PIT } \\
\text { rates on taxable income. } \\
\text { Shares held }>1 \text { year and of } \\
\text { less } 1 \% \text { of the nominal } \\
\text { capital: exempt (if more } \\
\text { than } 1 \% \text { of the nominal } \\
\text { capital: taxed as shares held } \\
\leq 1 \text { year). }\end{array}$ & $\begin{array}{l}\text { Exempt if occupied by } \\
\text { owner for a minimum } \\
\text { period of time. } \\
\text { No exemption where } \\
\text { residence is used in a } \\
\text { business. }\end{array}$ & $\begin{array}{l}\text { Taxed at marginal } \\
\text { ordinary PIT rates. }\end{array}$ \\
\hline Ireland & $\begin{array}{l}\text { Taxed at marginal } \\
\text { ordinary PIT rates }(20 \% \text { - } \\
40 \%)\end{array}$ & Taxed at flat $20 \%$ rate & $\begin{array}{l}\text { Exempt with land of up } \\
\text { to } 1 \text { acre. }\end{array}$ & $\begin{array}{l}\text { Taxed at marginal } \\
\text { ordinary PIT rates } \\
(20 \%-40 \%) \text {. }\end{array}$ \\
\hline Netherlands & $\begin{array}{l}\text { Presumptive capital } \\
\text { income tax treatment: a } \\
\text { return of } 4 \% \text { is deemed to } \\
\text { be received on the value } \\
\text { of the underlying } \\
\text { 'ordinary' shares } \\
\text { (irrespective of actual } \\
\text { return received); this } \\
\text { deemed return is taxed at } \\
\text { a rate of } 30 \% \text {; } 25 \% \text { flat } \\
\text { rate on dividends from a } \\
\text { substantial shareholding. }\end{array}$ & $\begin{array}{l}\text { Same presumptive capital } \\
\text { income tax treatment as } \\
\text { dividends. Realized capital } \\
\text { gains on shares that form a } \\
\text { substantial shareholding: } \\
\text { flat } 25 \% \text { rate. }\end{array}$ & $\begin{array}{l}\text { Exempt, provided the } \\
\text { residence is not used as } \\
\text { business asset. }\end{array}$ & $\begin{array}{l}\text { Same presumptive } \\
\text { capital income tax } \\
\text { treatment as } \\
\text { dividends. }\end{array}$ \\
\hline
\end{tabular}




\begin{tabular}{|c|c|c|c|c|}
\hline Norway & $\begin{array}{l}\text { Dividends are included in } \\
\text { taxable income and taxed } \\
\text { at the flat } 28 \% \text { rate; the } \\
\text { shareholder is entitled to a } \\
\text { full tax credit for the } \\
\text { underlying corporate tax } \\
\text { paid. }\end{array}$ & $\begin{array}{l}\text { Variable partial inclusion in } \\
\text { taxable income, taxed at } \\
28 \% \text { flat rate, under the so- } \\
\text { called RISK system, which } \\
\text { steps-up acquisition cost of } \\
\text { each share by pro-rate share } \\
\text { of retained (after tax) } \\
\text { profits. }\end{array}$ & $\begin{array}{l}\text { Exempt, provided seller } \\
\text { has owned residence for } \\
\geq 1 \text { year, and has used it } \\
\text { as principal residence } \\
\text { for at least one of two } \\
\text { previous years, and } \\
\text { provided the residence } \\
\text { is not used as a business } \\
\text { asset. }\end{array}$ & $\begin{array}{l}\text { Taxed at flat } 28 \% \\
\text { rate. }\end{array}$ \\
\hline Slovak Republic & Exempt. & $\begin{array}{l}\text { Included in net taxable } \\
\text { income, taxed at flat } 19 \% \\
\text { rate. }\end{array}$ & $\begin{array}{l}\text { Exempt if owned/used } \\
\text { as primary residence for } \\
\geq 2 \text { years. Taxable at } \\
19 \% \text { flat rate if used for } \\
\text { business or was rented } \\
\text { out. }\end{array}$ & $\begin{array}{l}\text { Included in net } \\
\text { taxable income, } \\
\text { taxed at flat } 19 \% \\
\text { rate. }\end{array}$ \\
\hline United States & $\begin{array}{l}\text { Qualified dividends taxed } \\
\text { at a flat } 15 \% \text { rate (reduced } \\
\text { to } 5 \% \text { for taxpayers with } \\
\text { marginal PIT rate of } 10 \% \\
\text { or } 15 \% \text { for ordinary tax } \\
\text { purposes). }\end{array}$ & $\begin{array}{l}\text { Shares held } \leq 1 \text { year: taxed } \\
\text { at marginal ordinary PIT } \\
\text { rate. } \\
\text { Shares held }>1 \text { year: taxed } \\
\text { at flat } 15 \% \text { tax rate (reduced } \\
\text { to } 5 \% \text { for taxpayers with } \\
\text { marginal PIT rate of } 10 \% \text { or } \\
15 \% \text { for ordinary tax } \\
\text { purposes). }\end{array}$ & $\begin{array}{l}\text { Gain is included in net } \\
\text { capital gain (net of an } \\
\text { exempt amount) and } \\
\text { taxed at lower capital } \\
\text { gains rate if owned and } \\
\text { occupied by taxpayer as } \\
\text { principal residence for } \geq \\
2 \text { years over prior } 5 \\
\text { years. }\end{array}$ & $\begin{array}{l}\text { Taxed at ordinary } \\
\text { marginal PIT rates. }\end{array}$ \\
\hline
\end{tabular}

Source: OECD Tax Database (www.oecd.org/ctp/taxdatabase), OECD (2006) "Taxation of capital gains of individuals" and European Tax Handbook (2005). 
Table 5. Standard and reduced (targeted) corporate income tax rates for small businesses (2005)

\begin{tabular}{|c|c|c|c|c|}
\hline & $\begin{array}{l}\text { Standard } \\
\text { corporate } \\
\text { income tax } \\
\text { rate }(\%) \\
(2005)^{(1)}\end{array}$ & $\begin{array}{l}\text { Small } \\
\text { business } \\
\text { corporate tax } \\
\text { rate(s) (\%) } \\
(2005)(2)\end{array}$ & $\begin{array}{l}\text { Range of taxable income } \\
\text { where the reduced rate } \\
\text { applies (2005) }\end{array}$ & $\begin{array}{l}\text { Other conditions to benefit from the } \\
\text { reduced rate(s) and/or additional } \\
\text { qualifications (2005) }{ }^{(3)}\end{array}$ \\
\hline Belgium & 33.99 & $\begin{array}{l}\text { 24.9775: } \\
31.93: \\
35.535:\end{array}$ & $\begin{array}{l}\text { EUR } 0-25000 \\
\text { EUR } 25000-90000 \\
\text { EUR } 90000-322500\end{array}$ & $\begin{array}{l}\text { The company cannot be an investment } \\
\text { company; entitlement to the reduced } \\
\text { rates is not granted to companies of } \\
\text { which at least } 50 \% \text { of the shares are } \\
\text { held by one or more companies and to } \\
\text { companies whose dividend distributions } \\
\text { exceed } 13 \% \text { of the paid-up capital at the } \\
\text { beginning of the financial year. }\end{array}$ \\
\hline Canada & 36.1 & $18.62^{(4)}$ & CAD $0-300000^{(5)}$ & $\begin{array}{l}\text { Applies only to the active business } \\
\text { income of a Canadian controlled private } \\
\text { corporation. Preferential rate phased out } \\
\text { for taxable capital between CAD } 10-15 \\
\text { million. The taxable income and } \\
\text { capital limits are shared amongst all } \\
\text { associated companies }\end{array}$ \\
\hline France & 35 & 15.225 & Profits: EUR $0-38120$ & $\begin{array}{l}\text { Firms owned at least for } 75 \% \text { by } \\
\text { individuals and with a turnover of EUR } \\
7630000 \text { or less. }\end{array}$ \\
\hline Japan & 39.54 & $\begin{array}{l}29.34: \\
30.85:\end{array}$ & $\begin{array}{l}\text { JPY } 0-4000000 \\
\text { JPY } 4000000-8000000\end{array}$ & $\begin{array}{l}\text { Reduced rates only for corporations } \\
\text { with capital of JPY } 100 \text { million or less. }\end{array}$ \\
\hline Korea & 27.5 & 14.3 & KRW $0-100$ million & \\
\hline Luxembourg & 30.4 & $\begin{array}{l}\text { 20.8: } \\
\text { 20.8 / 27.04: }\end{array}$ & $\begin{array}{l}\text { EUR } 0-10000 ; \\
\text { Firms with taxable income } \\
\text { between EUR } 10000-15000 \\
\text { pay } 20.8 \% \text { on profits up to EUR } \\
10000 \text { and } 27.04 \% \text { on } \\
\text { remainder such that at } \\
\text { EUR } 15000 \text {, they pay an } \\
\text { average rate of } 22.88 \% \\
\text { (standard central CIT rate) }\end{array}$ & \\
\hline Netherlands & 31.5 & 27 & EUR $0-22689$ & \\
\hline Spain & 35 & 30 & EUR 0 - 120202.41 & \\
\hline United Kingdom & 30 & $\begin{array}{l}0: \\
0 / 23.75:\end{array}$ & $\begin{array}{l}\text { Profits: GBP } 0-10000 \text {; } \\
\text { Firms with profits between } \\
\text { GBP } 10001-\text { GBP } 50000 \text { pay } \\
\text { nothing on the first GBP } 10000 \\
\text { and } 23.75 \% \text { on the remainder, } \\
\text { so that by the upper limit (GBP } \\
50000 \text { ), they are paying at an } \\
\text { average rate of } 19 \% \text {; } \\
\text { Profits GBP } 50000-300000 \text {. }\end{array}$ & $\begin{array}{l}\text { All limits for taxable profits are } \\
\text { proportionately reduced in cases where } \\
\text { there are associated companies, and } \\
\text { where the accounting period is less than } \\
12 \text { months. }\end{array}$ \\
\hline United States & 39.3 & $20.23^{(6)}$ & US\$ $0-50000$ & \\
\hline
\end{tabular}

1. Combined central government and sub-central government standard (top) corporate tax rate.

2. Combined central government and sub-central government corporate tax rate typically applying for or are targeted at 'small (incorporated) business', where such 'targeting' is on the basis of size alone (e.g. number of employees, amount of assets, turnover or taxable income) and not on the basis of expenditures or other targeting criteria.

3. This table summarises the main arguments presented in the Explanatory Annex to Table II.2 of the OECD Tax Database.

4. Includes the sub-central government small business tax rate for the Province of Ontario.

5. Different thresholds are applied by the provinces. Federal thresholds increased effective January 1, 2007.

6. The federal income tax rate of $15 \%$ applies to taxable income under US\$ $50000 ; 25 \%$ applies to taxable income over US\$ 50000 and under US\$ 75 000; 34\% applies to taxable income over US\$ 75000 and under US\$ 10 million; and 35\% applies to taxable income of US\$10 million or more. The benefit of lower rates is recaptured for taxable incomes between US\$100 000 and US\$ 18333333 (federal rates have to be increased with the sub-central rate).

Source: OECD Tax Database: www.oecd.org/ctp/taxdatabase and European Tax Handbook (2005). 
Table 6. Estimated effects of labour taxes on TFP: Industry-level ${ }^{1}$

The estimated empirical model is:

$\Delta I n T F P_{i, j, t}=\delta_{1} \Delta / n T F P_{F, j, t}+\delta_{2} \ln \left(\operatorname{TFP}_{i, j, t-1} / \operatorname{TFP}_{F, j, t-1}\right)+\delta_{3} H K_{i, j, t}+\beta I N D c h a r a c_{j}^{*} T A X_{i, t-1}+\varphi X_{i, j, t-1}+\sum_{i} \sum_{t} D_{i, t}+\sum_{j} D_{j}+\varepsilon_{i, j, t}$

\begin{tabular}{|c|c|c|c|c|}
\hline Dependent variable: TFP growth & (1) & $(2)$ & $(3)$ & $(4)$ \\
\hline \multicolumn{5}{|l|}{ Basic model } \\
\hline \multirow{2}{*}{ Leader TFP growth } & 0.06 & 0.06 & 0.05 & 0.06 \\
\hline & $(0.02)^{\star * *}$ & $(0.02)^{\star * *}$ & $(0.02)^{\star *}$ & $(0.02)^{\star * *}$ \\
\hline \multirow[t]{2}{*}{ TFP relative to leader TFP $(\mathrm{t}-1)$} & -0.01 & -0.01 & -0.01 & -0.01 \\
\hline & $(0.00)^{* * *}$ & $(0.00)^{\star * *}$ & $(0.00)^{* * *}$ & $(0.00)^{* * *}$ \\
\hline \multirow[t]{2}{*}{ Human capital (t-1) } & 0.01 & 0.01 & 0.01 & 0.01 \\
\hline & $(0.00)^{\star *}$ & $(0.00)^{\star *}$ & $(0.00)^{\star \star}$ & $(0.00)^{\star *}$ \\
\hline \multicolumn{5}{|l|}{ Interaction between industry characteristics \& tax } \\
\hline \multirow[t]{2}{*}{ Labour intensity \& social security contributions (t-1) } & -0.01 & & & \\
\hline & $(0.00)^{\star *}$ & & & \\
\hline \multirow[t]{2}{*}{ Labour intensity \& employer's social security contributions (t-1) } & & -0.01 & & \\
\hline & & $(0.00)^{\star *}$ & & \\
\hline \multirow[t]{2}{*}{ Labour intensity \& social security contributions (t-1) with low adm. extension } & & & & -0.01 \\
\hline & & & & $(0.01)$ \\
\hline \multirow[t]{2}{*}{ Labour intensity \& Social security contributions (t-1) with high adm. extension } & & & & -0.01 \\
\hline & & & & $(0.00)^{* *}$ \\
\hline \multirow[t]{2}{*}{ Entry rate $\&$ top personal income tax $(\mathrm{t}-1)$} & & & -0.04 & \\
\hline & & & $(0.01)^{\star \star \star}$ & \\
\hline \multicolumn{5}{|l|}{ Other policy variables } \\
\hline \multirow[t]{2}{*}{ Anti-competitive regulation impact (t-1) } & -0.03 & -0.03 & -0.01 & -0.03 \\
\hline & $(0.01)^{\star * *}$ & $(0.01)^{\star * *}$ & $(0.01)$ & $(0.01)^{\star * *}$ \\
\hline \multirow[t]{2}{*}{ Job turnover \& employment protection legislation } & & & -0.00 & \\
\hline & & & $(0.00)$ & \\
\hline Observations & 2802 & 2802 & 2910 & 2802 \\
\hline \multicolumn{5}{|l|}{ Fixed effects: } \\
\hline Country*year & yes & yes & yes & yes \\
\hline Industry & yes & yes & yes & yes \\
\hline
\end{tabular}

1. In the estimated empirical model $\Delta \operatorname{lnTFP} P_{i, j, t}, \Delta \operatorname{lnTFP} P_{F, j, t}, \ln \left(T F P_{i, j, t-1} / T F P_{F, j, t-1}\right), H K_{i, j, t}, I N D c h a r a c_{j} * T A X_{i, t-1}, X_{i, j, t-1},+\sum_{i} \sum_{i} D_{i, t}+\sum_{j} D_{j}$ refer respectively to (i) TFP growth in a country $i$, industry $j$ and year $t$; (ii) TFP growth in an industry in the best practice country; (iii) the relative difference between TFP in an industry and in that industry in the best practice country; (iv) a human capital measure; (v) the interaction term between industry characteristics and the relevant tax; (vi) other policy variables and (vii) fixed effects. The level of TFP is measured as the "Solowresidual" from a production function. The anti-competitive regulation impact is an industry-specific measure of the degree to which each industry in the economy is exposed to anti-competitive regulation in non-manufacturing sectors. In Column (4) the coefficients of the interaction term between social security contributions and labour intensity are distinguished by the degree of administrative extension of collective wage agreements. In Columns (1)-(2) and (4) the interaction term between job turnover and employment protection legislation is dropped as there may be some collinearity problems related to job turnover and labour intensity. The estimation sample includes 13 OECD countries and 21 industries over the 1981-2001 period. The results are robust to introducing other interaction terms with other tax variables. Robust standard errors are reported in the parentheses. ${ }^{*}$ denotes significance at $10 \% ; * *$ at $5 \% ; * * *$ at $1 \%$ 
Table 7. Estimated effects of corporate taxes on investment: firm-level ${ }^{1}$

The estimated empirical model is

$(I / K)_{i c s t}=\beta_{1}(I / K)_{i c s, t-1}+\beta_{2}(I / K)^{2}{ }_{i c s, t-1}+\beta_{3}(Y / K)_{i c s, t-1}+\beta_{4}(C F / K)_{i c s, t-1}+\beta_{5} U_{C t a x}{ }_{c s, t-1}+\gamma_{s}+\gamma_{c t}+e_{i c s t}$ Dependent Variable: Investment-to-capital ratio

(1)

$(2)$

Basic model

Investment-to-capital ratio (t-1)

$0.532^{* * *} \quad 0.531^{* * *} \quad 0.534^{* * *}$

Investment-to-capital ratio squared (t-1)

(0.026)

(0.026)

$(0.026)$

Investment-to-capital ratio squared (t-1)

$-0.415^{\star * *}$

$-0.414^{* * *}$

$-0.418^{* * *}$

Output-to-capital ratio (t-1)

$(0.025)$

(0.025)

(0.025)

Cashflow-to-capital ratio (t-1)

$0.000^{\star * *}$

$0.000^{* * *}$

$0.000^{* * *}$

$0.048^{\star \star *}$

(0.000)

(0.000)

Tax adjusted user cost (t-1)

(0.003)

$0.048^{* * *}$

$0.047^{* * *}$

$-0.829^{* *}$

(0.003)

(0.003)

Interactions between firm \& sector characteristics \& tax

Profitability \& tax adjusted user cost

(0.410) (0.689)

Tax adjusted user cost (Age $<6 \&$ Empl<30)

Tax adjusted user cost (Age<6\&Empl>=30)

Tax adjusted user cost $($ Age $>=6 \& E m p l<30)$

Tax adjusted user cost (Age $>=6 \& E \mathrm{mpl}>=30)$

Long-run tax adjusted user cost elasticity

$-0.69$

211.599

\section{Fixed effects:}

211,599

211,599

211,599

Sector

Size-age

$\begin{array}{ccc}\text { yes } & \text { yes } & \text { yes } \\ \text { no } & \text { no } & \text { yes } \\ \text { yes } & \text { yes } & \text { yes } \\ 0.12 & 0.12 & 0.12\end{array}$

\section{$\mathrm{R}^{2}$}

0.12

0.12

0.12

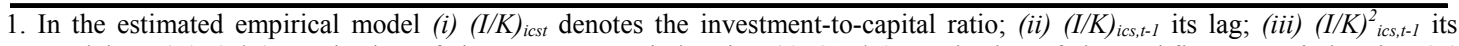
squared lag; (iv) $(Y / K)_{i c s, t-1}$ the lag of the output-to-capital ratio; (v) $(C F / K)_{i c s, t-1}$ the lag of the cashflow-to-capital ratio; (vi) $U_{C t a x}{ }_{c s, t-1}$ the lag of the tax adjusted user cost and (vii) $\gamma_{s}$ and $\gamma_{c t}$ sector and country-year fixed effects, respectively. The estimation sample contains 12 European OECD countries and only observations with investment ratios beween 0 and 1 . Robust standard errors corrected for clustering at the country-sector level in parentheses. $*$ denotes significant at $10 \% ; * *$ at $5 \% ; * * *$ at $1 \%$ 
Table 8. Estimated effects of corporate taxes on investment: Industry-level ${ }^{1}$

The estimated empirical model is:

$\operatorname{In}(I / K)_{i, j, t}=\beta_{1} \operatorname{In}(I / K)_{i, j, t-1}+\beta_{2} U \operatorname{Ctax}_{i, j, t-1}+\beta_{3} \operatorname{DIn} Y_{i, j, t-1}+\beta_{4} P M R_{i, j, t-1}+\varepsilon_{i, j, t}$,

\begin{tabular}{lll}
\hline & $(1)$ & $(2)$ \\
\hline Dependent variable: log of investment-to-capital OLS & System GMM \\
\hline Log of investment-to-capital ratio (t-1) & 0.66 & 0.73 \\
& $(0.02)^{\star * *}$ & $(0.05)^{\star * *}$ \\
Log of tax adjusted user cost (t-1) & -0.12 & -0.26 \\
& $(0.03)^{\star * *}$ & $(0.11)^{\star * *}$ \\
Log difference in value added (t-1) & 0.35 & 0.65 \\
& $(0.10)^{\star * *}$ & $(0.07)^{\star * *}$ \\
Anti-competitive regulation impact (t-1) & -0.21 & 0.33 \\
& $(0.08)^{\star * *}$ & $(0.39)$ \\
\hline Long-run tax adjusted user cost elasticity & -0.35 & -0.98 \\
\hline Observations & 3818 & 3818 \\
\hline Hansen J test & & 0.334 \\
Prob > chi2 = & & \\
Fixed effects & yes & yes \\
country*industry & yes \\
year
\end{tabular}

1. In the estimated empirical model $(I / K)_{i, j, t}, U \operatorname{Ctax}_{i, j, t-1,}, D \ln Y_{i, j, t-1}$ and $P M R_{i, j, t-1}$ refer respectively to (i) investment-to-capital ratio in country $i$, industry $j$ and year $t$; (ii) the tax adjusted user cost; (iii) the relative change in value added and (iv) the impact of anti-competitive regulation. The anti-competitive regulation impact is an industry-specific measure of the degree to which each industry in the economy is exposed to anticompetitive regulation in non-manufacturing sectors. The long run elasticity is computed as $\beta_{2} /\left(1-\beta_{1}\right)$. The effects are similar when a non-log version of the investment equation is estimated. The estimation sample includes 16 OECD countries and 21 industries for period 1983-2001. Robust standard errors are reported in the parentheses. ${ }^{*}$ denotes significance at $10 \% ; * *$ at $5 \% ; * * *$ at $1 \%$. 


\section{Table 9. Estimated effects of corporate taxes on TFP: firm-level ${ }^{1}$}

The estimated empirical model is

$\Delta / n$ TFP $_{i c s t}=d_{1}$ DInTFP $_{F c s t}+d_{2} \operatorname{In}\left(T F P_{i c s, t-1} / T_{F P P_{F c s, t-1}}\right)+d_{3}$ Profit $_{s}{ }^{*} T A X_{c, t-1}+\gamma_{s}+\gamma_{c t}+e_{i c s t}$

Dependent Variable: TFP growth

(1)

(2)

(3)

\section{Basic Model}

Leader TFP Growth

$0.173^{\star * *}$

$0.173^{* * *}$

$0.501^{* * *}$

TFP Relative to Leader (t-1)

(0.019) (0.019) (0.022)

$-0.190^{* * *}-0.190^{* * *}-0.115^{* * *}$

(0.015) (0.015) (0.010)

Interactions between firm \& sector characteristics \& tax

Profitability \& tax

$-0.307^{* *}$

(0.128)

Profitability \& tax $($ Age $<6 \& E m p l<30)$

Profitability \& tax (Age<6\&Empl>=30)

Profitability \& tax (Age>=6\&Empl<30)

Profitability \& tax (Age>=6\&Empl $>=30)$

$(0.134)$

Declining \& profitability \& tax

Rising \& profitability \& tax

Observations

(0.090)

Fixed effects:

287,727

287,727 287,727

Sector

\begin{tabular}{ccc} 
yes & no & no \\
no & yes & no \\
no & no & yes \\
yes & yes & yes \\
0.10 & 0.10 & 0.44 \\
\hline
\end{tabular}

1. In the estimated empirical model (i) $\triangle \operatorname{lnTFP} P_{i c s t}$ denotes TFP growth in firm $i$, country $c$, sector $s$ and year $t$; (ii) $\Delta \ln T F P_{F c s t}$ denotes TFP growth in the technological leader firm; (iii) $\left(T F P_{i c s, t-1} / T F P_{F c s, t-1}\right.$ ) denotes the inverse of distance to the leader; (iv) Profit ${ }_{s}^{*} T A X_{c, t}$ the interaction between profitability and the corporate tax and (v) $\gamma_{s}$ and $\gamma_{c t}$ sector and countryyear fixed effects, respectively. The estimation sample contains 12 European OECD countries over the period 1998-2004. TFP is the residual of a Cobb-Douglas production function estimated at the country-sector level. Robust standard errors corrected for clustering at the country-sector level in parentheses. * denotes significant at $10 \%$; $* *$ at $5 \%$; *** at $1 \%$ 
Table 10. Estimated effects of corporate taxes on TFP: Industry-level ${ }^{1}$

The estimated empirical model is:

$\Delta \operatorname{lnTFP} P_{i, j, t}=\delta_{1} \Delta / n T F P_{F, j, t}+\delta_{2} \operatorname{In}\left(\operatorname{TFP}_{i, j, t-1} / T F P_{F, j, t-1}\right)+\delta_{3} H K_{i, j, t}+\beta I N D \operatorname{Inarac} c_{j}^{*} T A X_{i, t-1}+\varphi X_{i, j, t-1}+\sum_{i} \sum_{t} D_{i, t}+\sum_{j} D_{j}+\varepsilon_{i, j, t}$

\begin{tabular}{|c|c|c|}
\hline Dependent variable: TFP growth & $(1)$ & $(2)$ \\
\hline \multicolumn{3}{|l|}{ Basic model } \\
\hline \multirow[t]{2}{*}{ Leader TFP growth } & 0.04 & 0.05 \\
\hline & $(0.02)^{*}$ & $(0.02)^{\star *}$ \\
\hline \multirow[t]{2}{*}{ TFP relative to leader TFP $(\mathrm{t}-1)$} & -0.01 & -0.01 \\
\hline & $(0.00)^{* * *}$ & $(0.00)^{* * *}$ \\
\hline \multirow[t]{2}{*}{ Human capital (t-1) } & 0.01 & 0.01 \\
\hline & $(0.00)^{\star *}$ & $(0.00)^{\star *}$ \\
\hline \multicolumn{3}{|l|}{ Interaction between industry characteristics \& tax } \\
\hline \multirow[t]{2}{*}{ Profitability \& Corporate tax (t-1) } & -0.04 & \\
\hline & $(0.01)^{* * *}$ & \\
\hline \multirow[t]{2}{*}{ R\&D intensity \& R\&D tax incentives (t-1) } & & 0.003 \\
\hline & & $(0.001)^{\star *}$ \\
\hline \multicolumn{3}{|l|}{ Other policy variables } \\
\hline \multirow[t]{2}{*}{ Anti-competitive regulation impact $(\mathrm{t}-1)$} & -0.01 & -0.01 \\
\hline & $(0.01)^{\star *}$ & $(0.01)^{\star *}$ \\
\hline \multirow[t]{2}{*}{ Job turnover \& employment protection legislation } & -0.00 & -0.00 \\
\hline & $(0.00)$ & $(0.00)$ \\
\hline Observations & 2910 & 2767 \\
\hline \multicolumn{3}{|l|}{ Fixed effects: } \\
\hline Country*year & yes & yes \\
\hline Industry & yes & yes \\
\hline
\end{tabular}

1. In the estimated empirical model $\triangle \ln T F P_{i, j, t}, \Delta \ln T F P_{F, j, t}, \ln \left(T F P_{i, j, t-1} / T F P_{F, j, t-1}\right), H K_{i, j, t}, I N D c h a r a c_{j} * T A X_{i, t-1}, X_{i, j, t-1},+\sum_{i} \sum_{i} D_{i, t}+\sum_{j} D_{j}$ refer respectively to (i) TFP growth in a country $i$, industry $j$ and year $t$; (ii) TFP growth in an industry in the best practice country; (iii) the relative difference between TFP in an industry and in that industry in the best practice country; (iv) a human capital measure; (v) the interaction term between industry characteristics and the relevant tax; (vi) other policy variables and (vii) fixed effects. TFP is measured as the "Solow-residual" from a production function. The anti-competitive regulation impact is an industry-specific measure of the degree to which each industry in the economy is exposed to anti-competitive regulation in non-manufacturing sectors. The estimation sample includes 13 OECD countries and 21 industries over the 1981-2001 period. The results are robust to introducing other interaction terms with other tax variables. Robust standard errors are reported in the parentheses. * denotes significance at $10 \%$; ** at $5 \%$; ** at $1 \%$. 


\section{Table 11. Estimated cross-country effects of the tax mix on long-run GDP per capita ${ }^{1}$}

The estimated empirical model is:

$\Delta \ln y_{\mathrm{it}}=-\Phi_{\mathrm{i}}\left(\ln y_{\mathrm{it}-1}-\theta_{1} \ln s^{\mathrm{k}}{ }_{\mathrm{it}}-\theta_{2} \ln h_{\mathrm{it}}+\theta_{3} n_{\mathrm{it}}+\sum \theta_{\mathrm{j}} \ln V^{\mathrm{j}}{ }_{\mathrm{it}}-\mathrm{a}_{\mathrm{it}}\right)+\mathrm{b}_{1 \mathrm{i}} \Delta \ln s^{\mathrm{k}}{ }_{\mathrm{it}}+\mathrm{b}_{2 \mathrm{i}} \Delta \ln h_{\mathrm{it}}+\mathrm{b}_{3 \mathrm{i}} \Delta n_{\mathrm{it}}+\sum \mathrm{b}_{\mathrm{ji}} \Delta \ln V_{\mathrm{it}}^{\mathrm{j}}+\varepsilon_{\mathrm{it}}$

\begin{tabular}{|c|c|c|c|c|c|}
\hline Dependent Variable: Log GDP p.c. & (1) & $(2)$ & (3) & (4) & (5) \\
\hline \multicolumn{6}{|l|}{ Baseline Model } \\
\hline Physical Capital & $\begin{array}{l}0.18^{* * *} \\
(0.05)\end{array}$ & $\begin{array}{l}0.25^{* * *} \\
(0.05)\end{array}$ & $\begin{array}{l}0.18^{* * *} \\
(0.05)\end{array}$ & $\begin{array}{l}0.16^{* * *} \\
(0.05)\end{array}$ & $\begin{array}{r}0.21 \\
(0.45)\end{array}$ \\
\hline Human Capital & $\begin{array}{l}1.19^{* * *} \\
(0.13)\end{array}$ & $\begin{array}{l}1.30^{* * *} \\
(0.12)\end{array}$ & $\begin{array}{l}1.18^{* * *} \\
(0.13)\end{array}$ & $\begin{array}{l}1.40^{* * *} \\
(0.11)\end{array}$ & $\begin{array}{l}1.57^{* * *} \\
(0.11)\end{array}$ \\
\hline Population Growth & $\begin{array}{l}-0.08^{* * *} \\
(0.01)\end{array}$ & $\begin{array}{l}-0.08^{* * *} \\
(0.01)\end{array}$ & $\begin{array}{l}-0.07^{* * *} \\
(0.01)\end{array}$ & $\begin{array}{l}-0.07^{* * *} \\
(0.01)\end{array}$ & $\begin{array}{l}-0.07^{* * *} \\
(0.01)\end{array}$ \\
\hline \multicolumn{6}{|l|}{ Control variable } \\
\hline $\begin{array}{l}\text { Overall Tax Burden } \\
\text { (Total revenues / GDP) }\end{array}$ & $\begin{array}{l}-0.27^{* * *} \\
(0.05)\end{array}$ & $\begin{array}{l}-0.24^{* * *} \\
(0.05)\end{array}$ & $\begin{array}{l}-0.26^{* * *} \\
(0.05)\end{array}$ & $\begin{array}{l}-0.22 * * * \\
(0.04)\end{array}$ & $\begin{array}{l}-0.14^{* * *} \\
(0.04)\end{array}$ \\
\hline \multicolumn{6}{|l|}{ Tax structure variables } \\
\hline Income Taxes & $\begin{array}{l}-0.98^{* * *} \\
(0.20)\end{array}$ & & & & \\
\hline Personal Income Taxes & & $\begin{array}{l}-1.13^{* * *} \\
(0.19)\end{array}$ & & & \\
\hline Corporate Income Taxes & & $\begin{array}{l}-2.01^{* * *} \\
(0.32)\end{array}$ & & & \\
\hline Consumption \& Property Taxes & & & $\begin{array}{l}0.93^{* * *} \\
(0.20)\end{array}$ & & \\
\hline $\begin{array}{l}\text { Consumption taxes } \\
\text { (excl. property taxes) }\end{array}$ & & & & $\begin{array}{l}0.74^{* * *} \\
(0.18)\end{array}$ & $\begin{array}{l}0.72 * * * \\
(0.19)\end{array}$ \\
\hline Property taxes & & & & $\begin{array}{l}1.45^{* * *} \\
(0.43)\end{array}$ & \\
\hline Property taxes: Recurrent Taxes on Immovable Property & & & & & $\begin{array}{l}2.47^{* * *} \\
(0.84)\end{array}$ \\
\hline Property taxes: Other property taxes & & & & & $\begin{array}{r}-0.34 \\
(0.51)\end{array}$ \\
\hline Observations & 696 & 675 & 696 & 696 & 698 \\
\hline Revenue-neutrality achieved by adjusting & $\begin{array}{l}\text { Cons. \& } \\
\text { Prop. Taxes }\end{array}$ & $\begin{array}{l}\text { Cons. \& } \\
\text { Prop. Taxes }\end{array}$ & $\begin{array}{l}\text { Income } \\
\text { Taxes }\end{array}$ & $\begin{array}{l}\text { Income } \\
\text { Taxes }\end{array}$ & $\begin{array}{l}\text { Income } \\
\text { Taxes }\end{array}$ \\
\hline
\end{tabular}

1. In the estimated model, $\mathrm{y}$ refers to output per capita, $\mathrm{s}^{\mathrm{k}}$ to the investment rate into physical capital, $\mathrm{h}$ to human capital, $\mathrm{n}$ to the population growth rate, respectively. The vector $\mathrm{V}$ contains a set of policy variables. All equations include short-run dynamics, countryspecific intercepts and country-specific time controls. Standard errors are in brackets. *: significant at $10 \%$ level; ** at $5 \%$ level; *** at $1 \%$ level. 
Figure 1.Tax-to-GDP ratios in the OECD area (1975-2006)

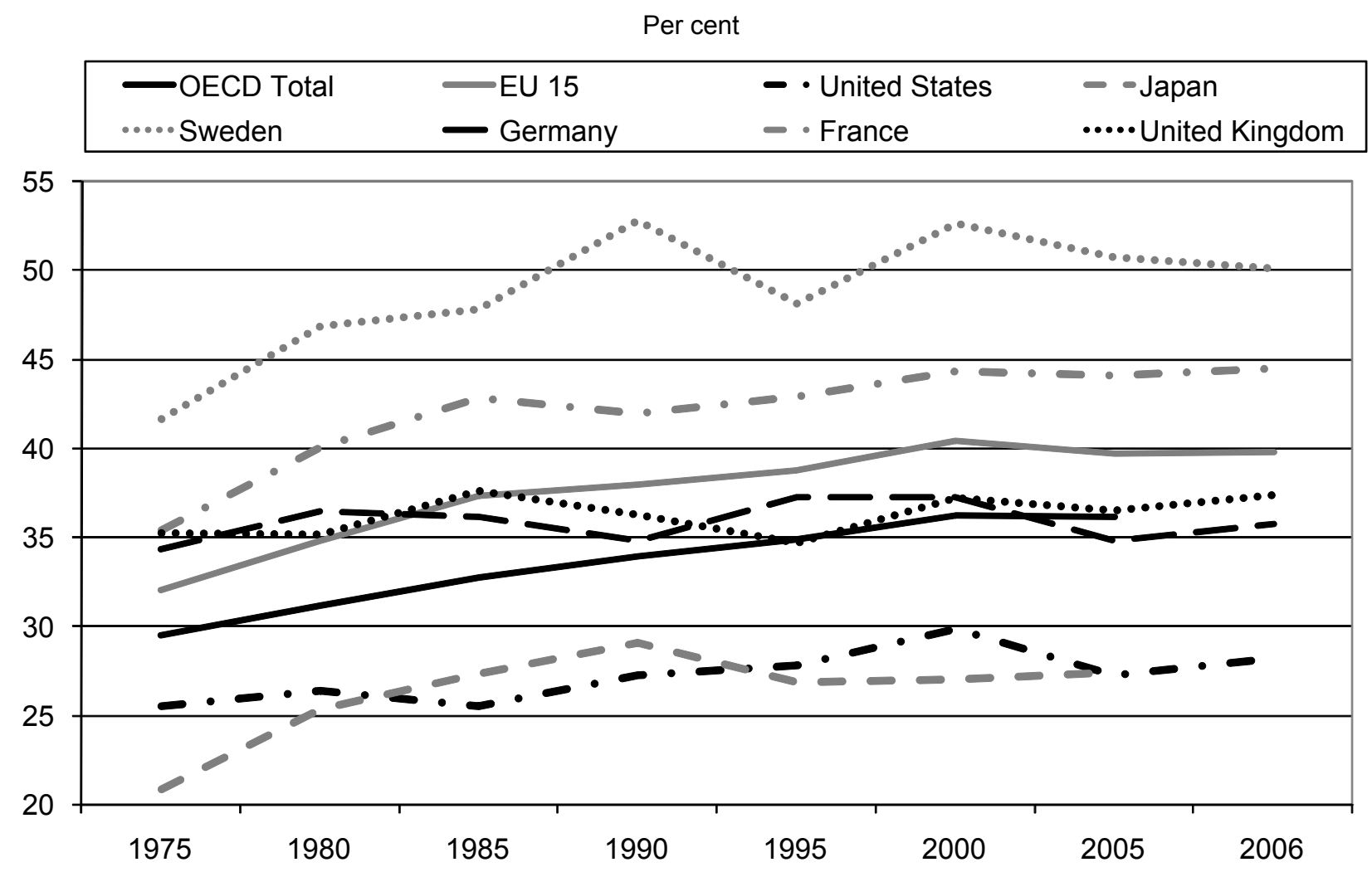

Source : OECD (2007) Revenue Statistics 1965-2006

Figure 2. Tax structures in the OECD, 1985 and 2005 (selected countries/areas)

(per cent)

1985

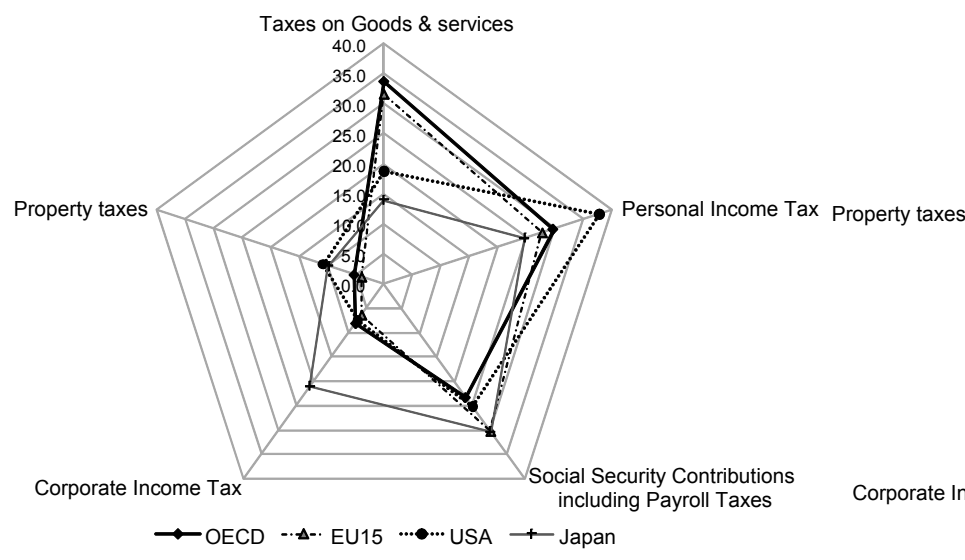

2005

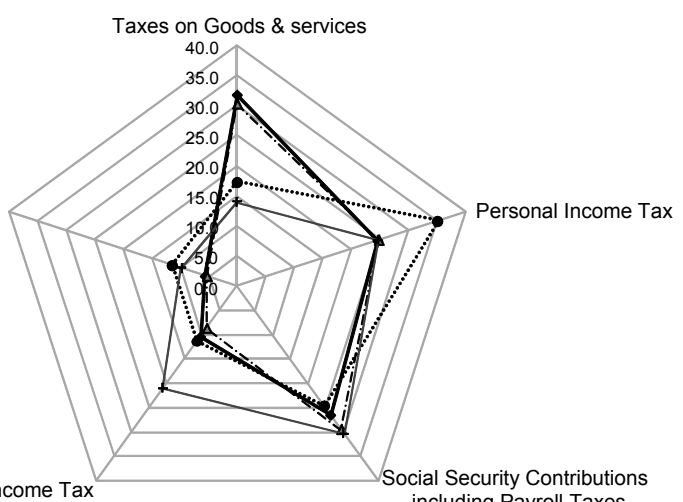

$\rightarrow$ OECD -. A-EU15 ……US + Japan

Source : OECD Revenue Statistics (2007). 
Figure 3. Revenues from environmentally-related taxes in per cent of GDP

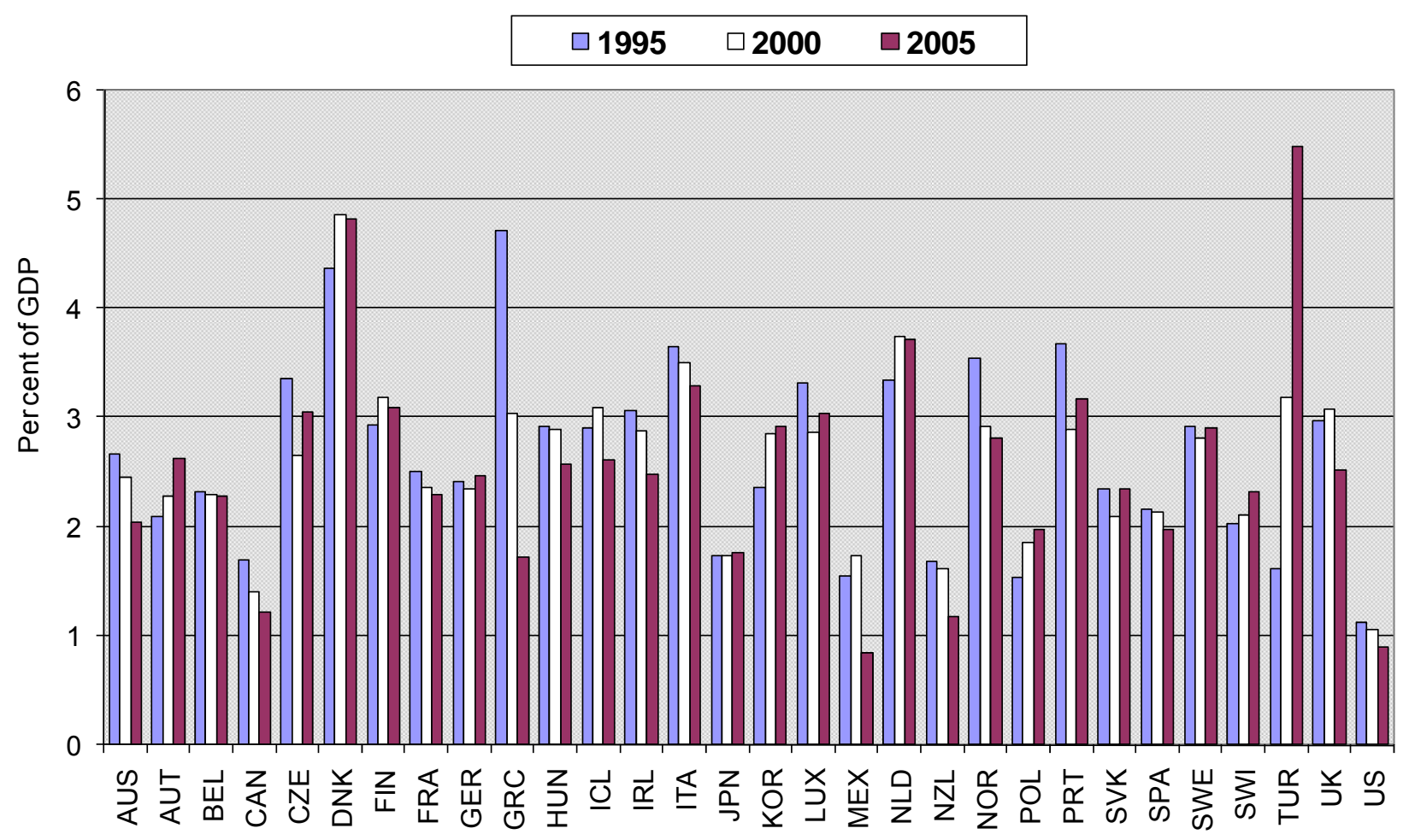

Note: 2005 data not available in the case of France and Iceland (2004 data used) and Korea (2003 data)

Source: OECD Revenue Statistics. 
Figure 4. The evolution of property taxes (as a percentage of GDP)

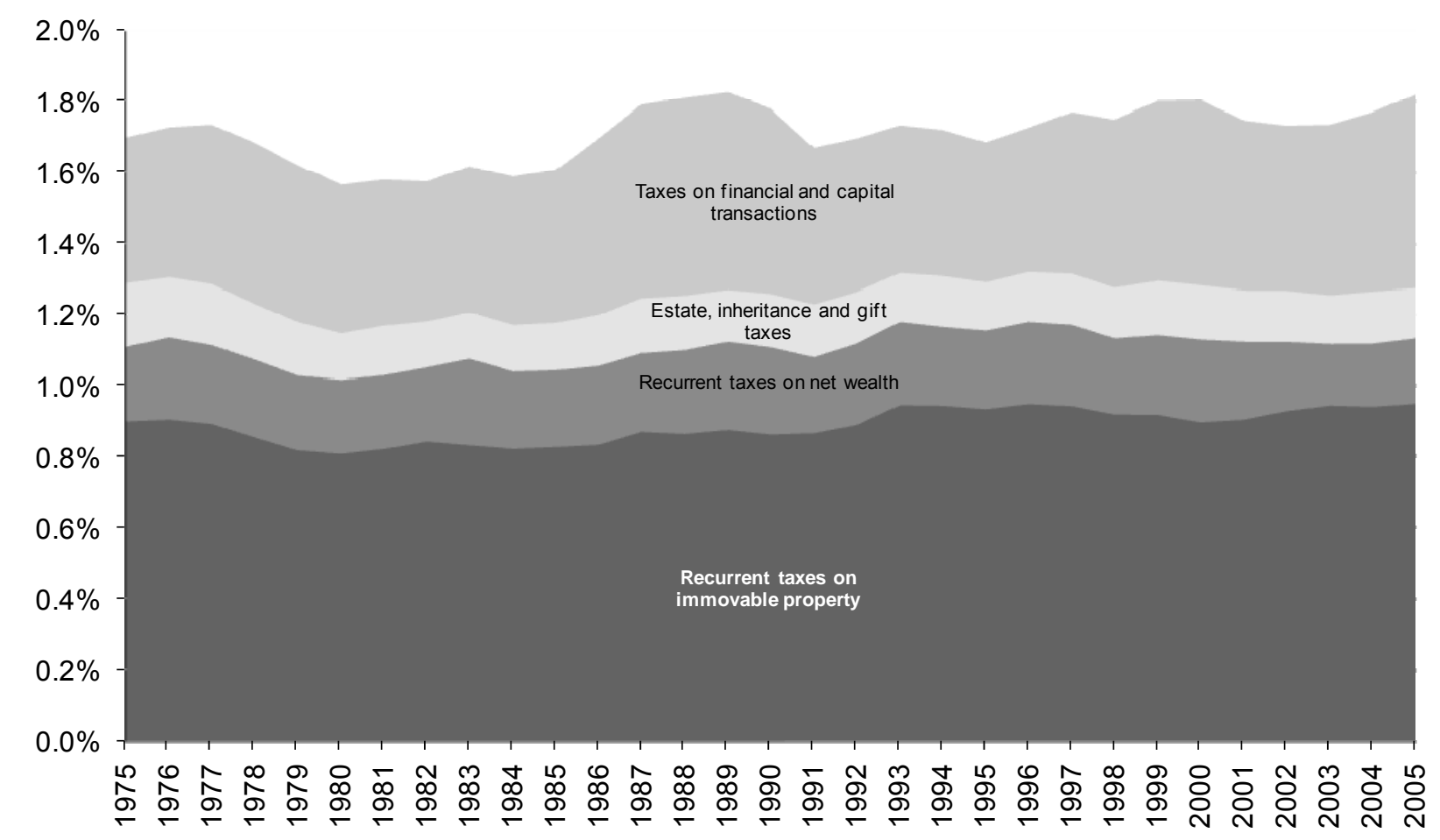

Source: OECD Revenue Statistics. 
Figure 5.Top statutory personal income tax rates on wage income

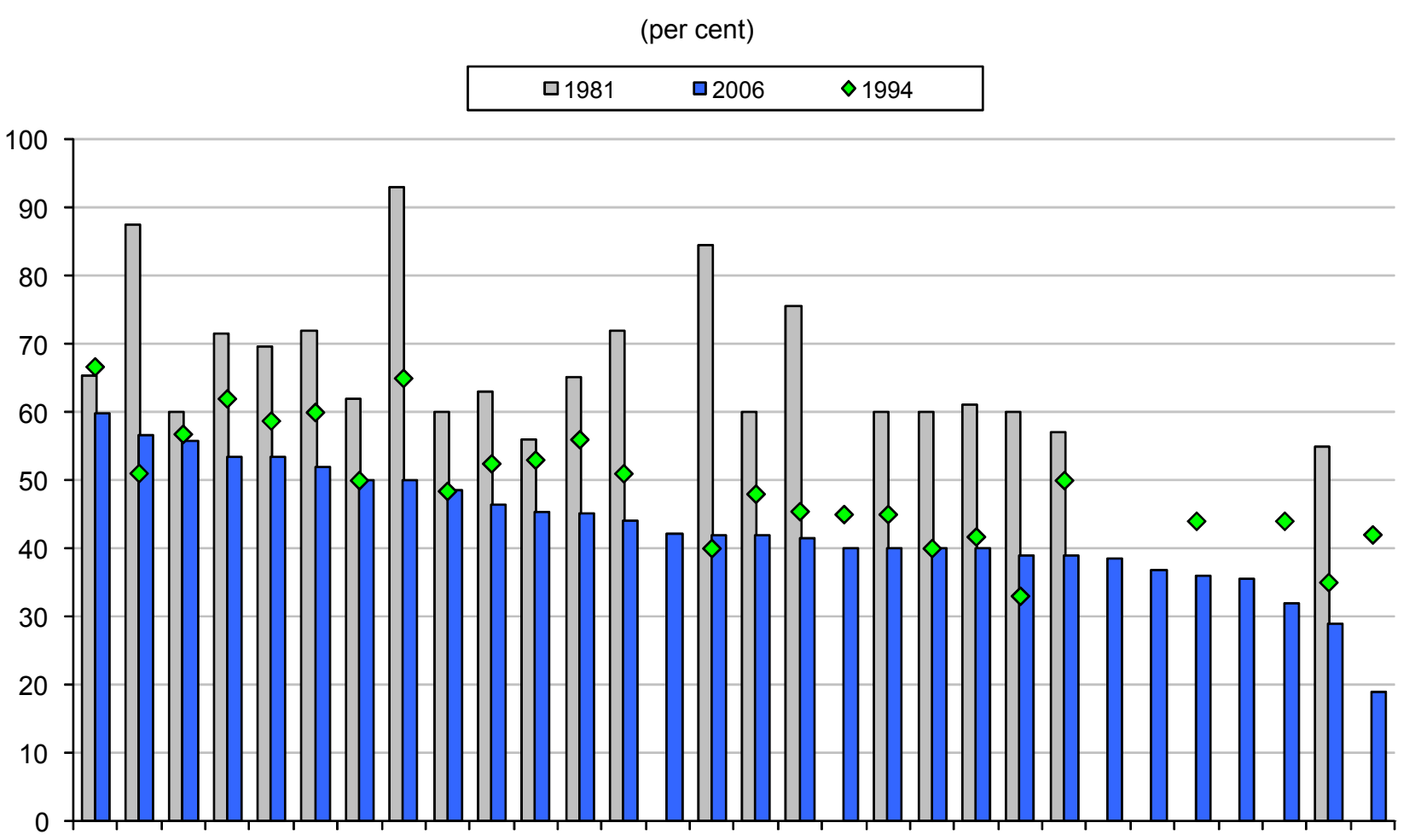

Source: OECD Taxing Wages 2006. 
Figure 6. Average income tax for a single individual at average earnings

(in per cent of gross wage earnings)

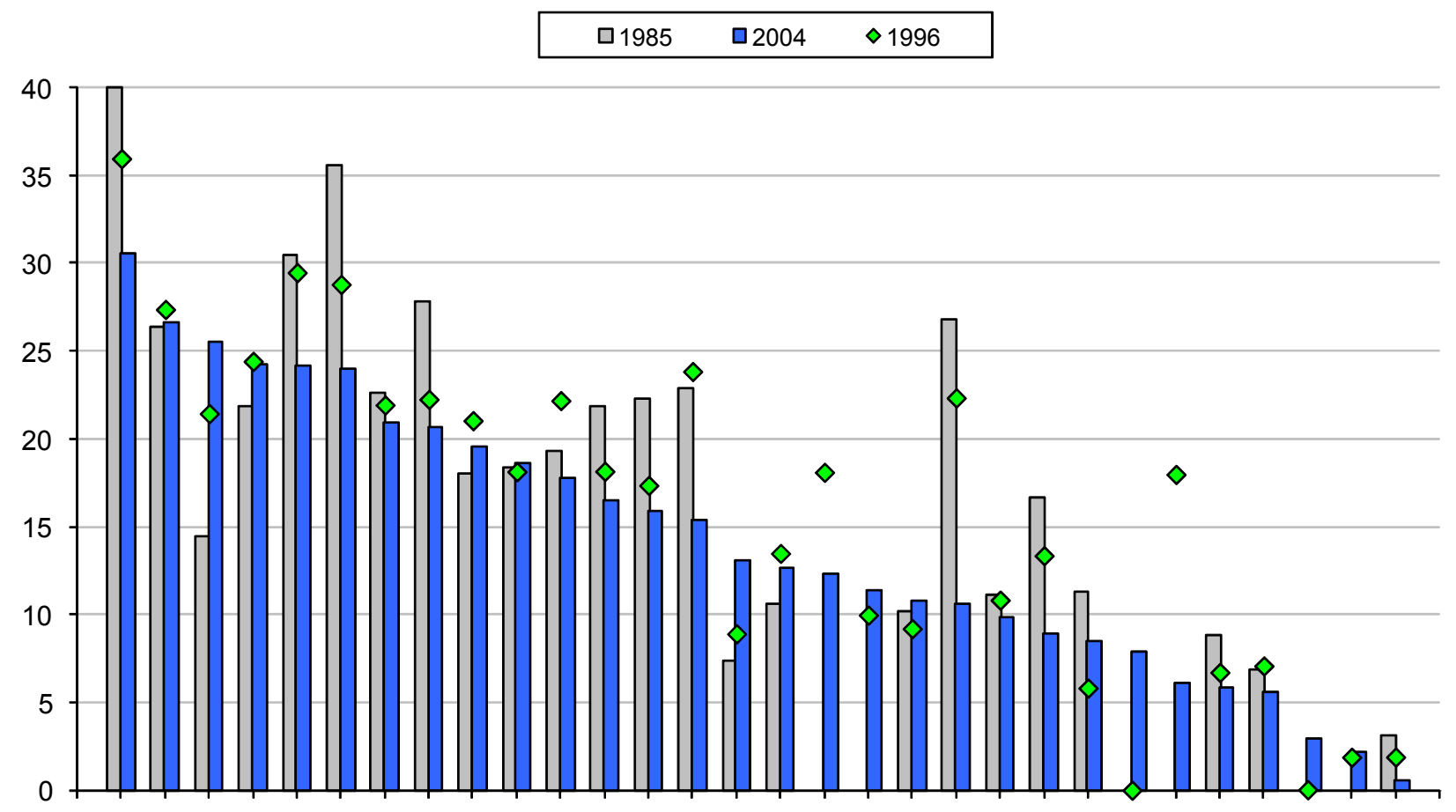

Source: OECD Taxing Wages 2006. 
Figure 7. Statutory income tax progressivity for single individuals at average earnings ${ }^{1}$ (index increasing with progressivity)

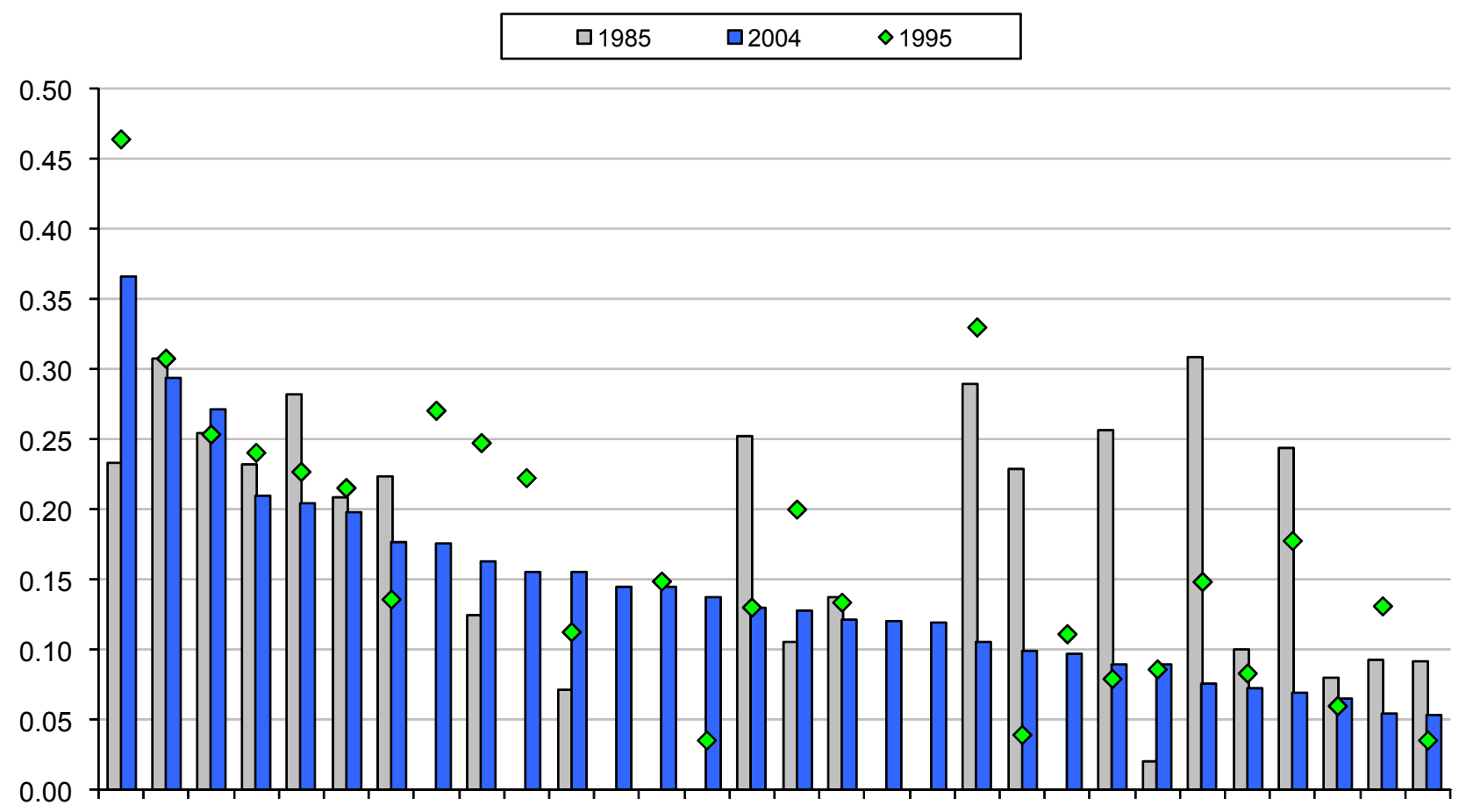

1. The measure of progressivity used is the difference between the marginal and average personal income tax rates, divided by one minus the average personal income tax rate, for an average single production worker. Higher numbers indicate higher progressivity.

Source: OECD Taxing Wages 2006. 
Figure 8. Tax wedge for a single individual at average earnings ${ }^{1}$

(in per cent of total labour costs)

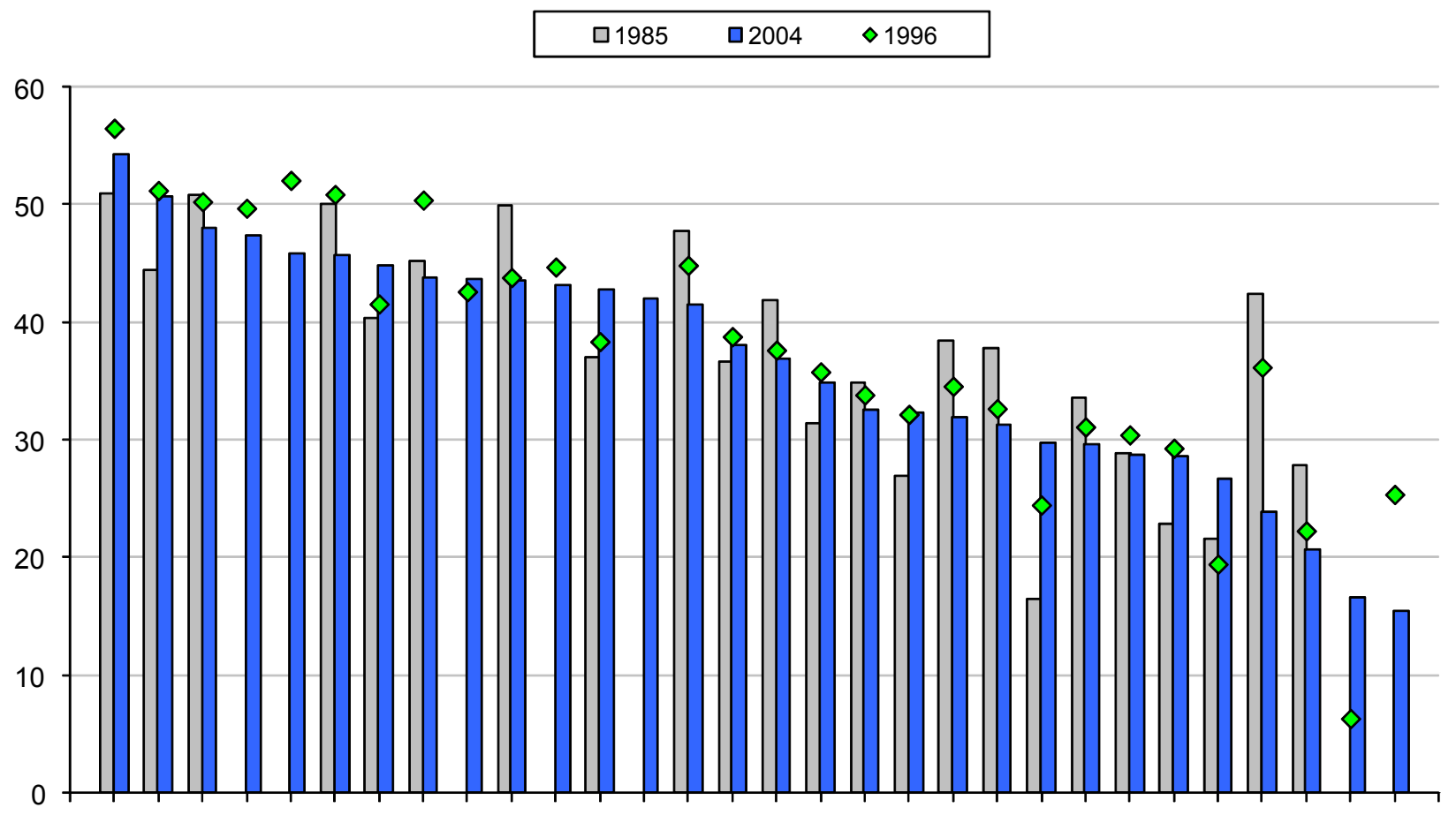

1. The tax wedge measures the amount of personal income tax, employees' and employers' social security contribution and payroll taxes less cash benefits as a proportion of labour costs, defined as the wage plus employers' social security contributions and payroll taxes.

Source: OECD Taxing Wages 2006. 
Figure 9. Statutory corporate income tax rates

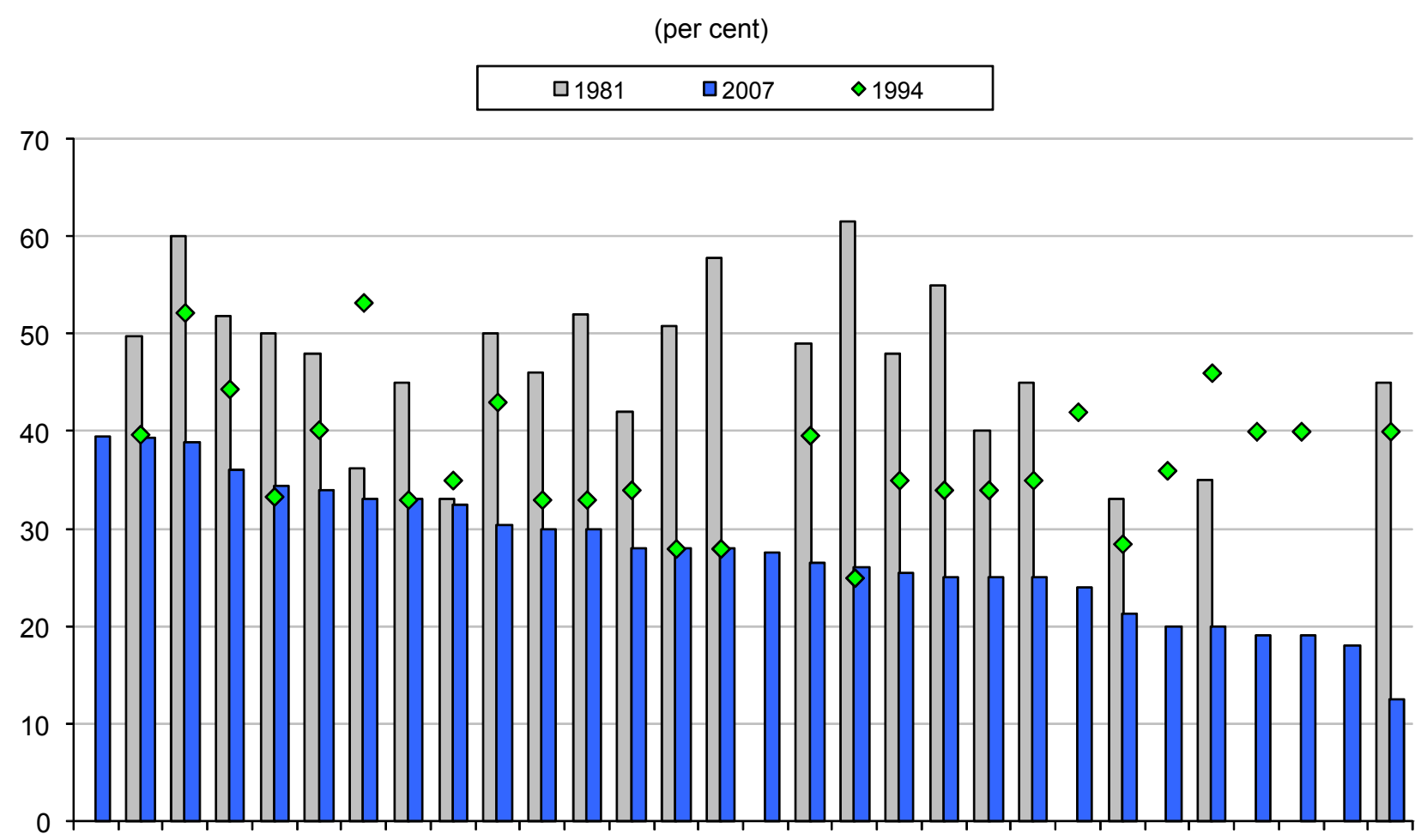

Source: OECD Tax database. 
Figure 10. Overall statutory tax rates on dividend income (2000 and 2007)

(per cent)

$\square$ Part of CIT in overall tax rate on dividends $\quad$ Part of PIT in overall tax rate on dividends

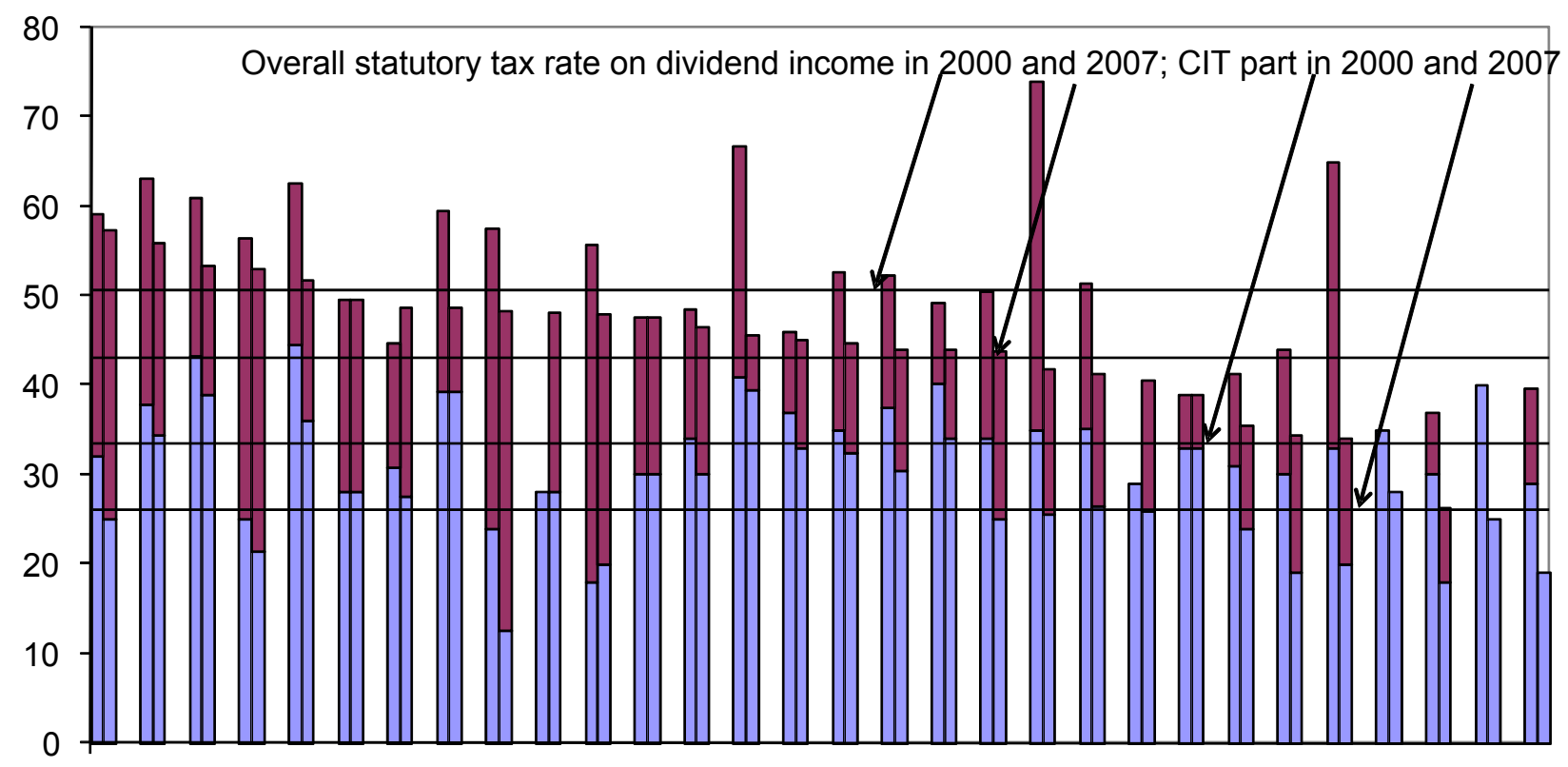

Source: OECD Tax database. 
Figure 11. Tax subsidies for one US $\$$ of research and development in OECD countries (2007) ${ }^{1}$

(in cents)

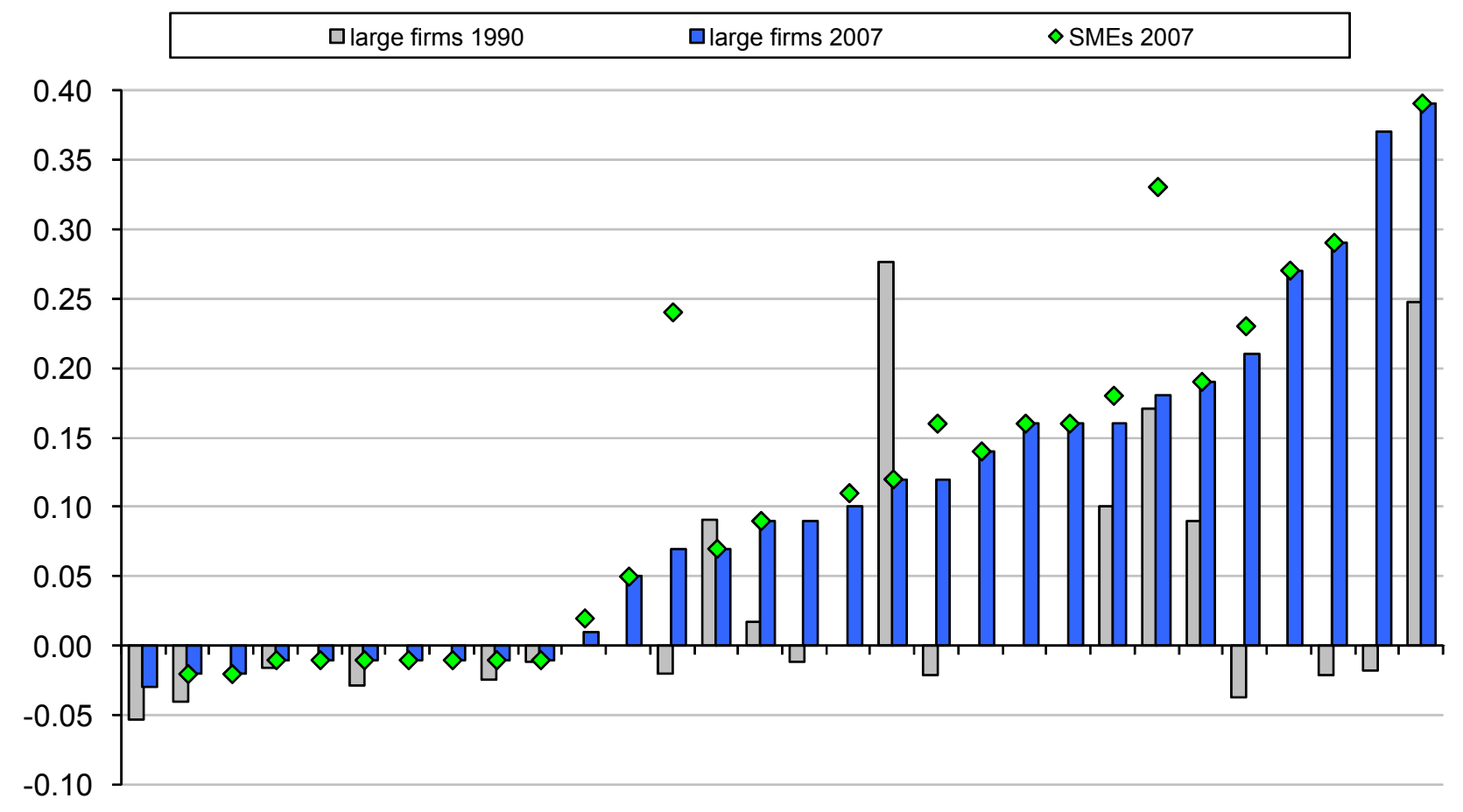

1. This figure shows the amount of tax relief for a unit of R\&D expenditure compared to the benchmark situation of the immediate expensing of the R\&D expenses." Negative values do not necessarily imply that R\&D is not taxed favourably but only imply that R\&D receives a tax treatment that is less generous than would be the case under full immediate expensing

Source: OECD Scoreboard.

Figure 12. Taxes affect the determinants of growth
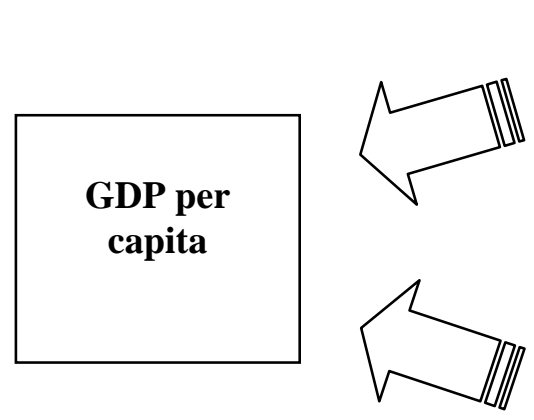

\section{Labour Utilisation}

- Employment

- Hours worked

Labour Productivity

- Physical capital

- Human capital

- Efficiency in the use of inputs

(Total Factor Productivity)

Taxes

- Consumption

- Property

- Personal income

- Corporate income 
Figure 13. C-efficiency for VAT (Average 2002-2004) ${ }^{1}$

(index increasing in efficiency)

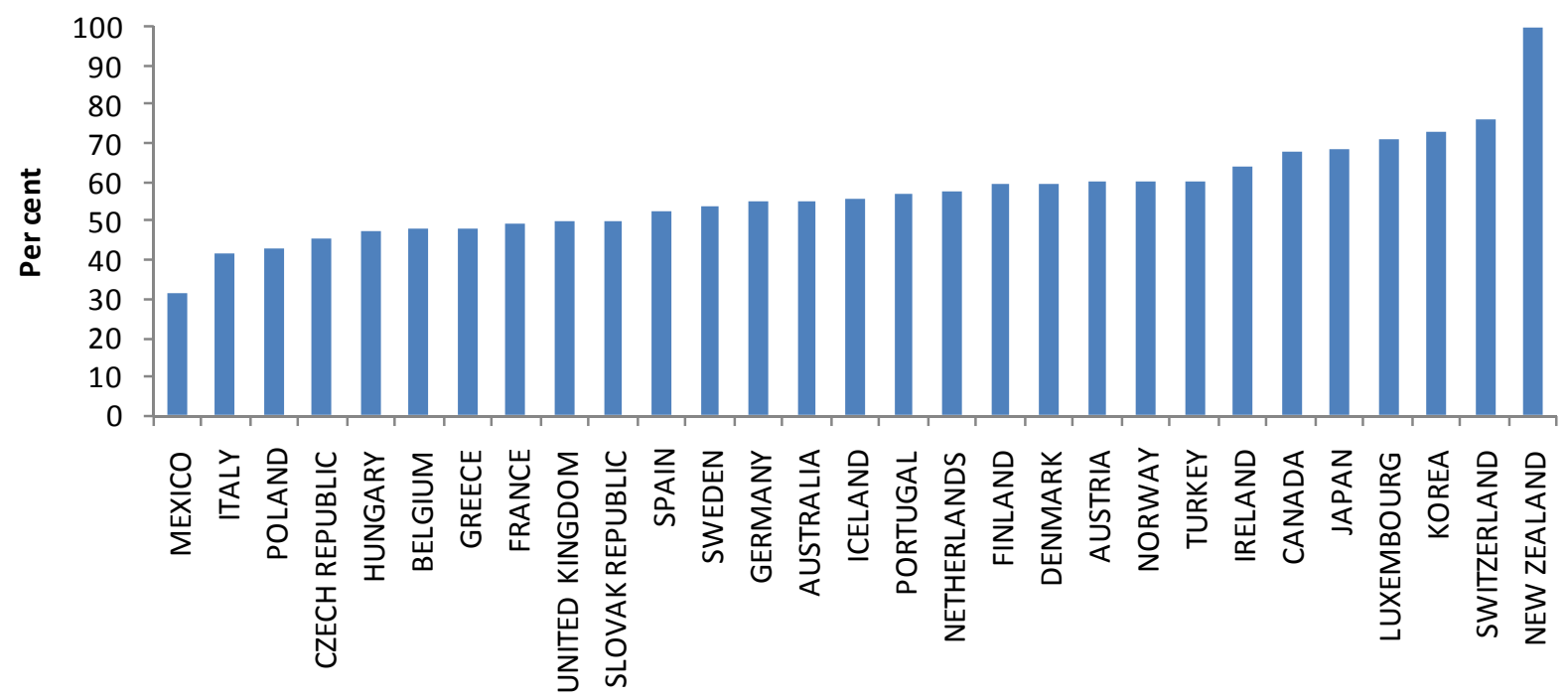

1. The c-efficiency is defined as the ratio of the share of VAT revenues to consumption divided by the standard rate, expressed as a percentage $((\text { VAT revenues/National consumption } \times 100) /(\text { Standard VAT rate }))^{*} 100$

Source: OECD Consumption Tax Trends 2006 and OECD calculations. 
Figure 14. Tax matrix

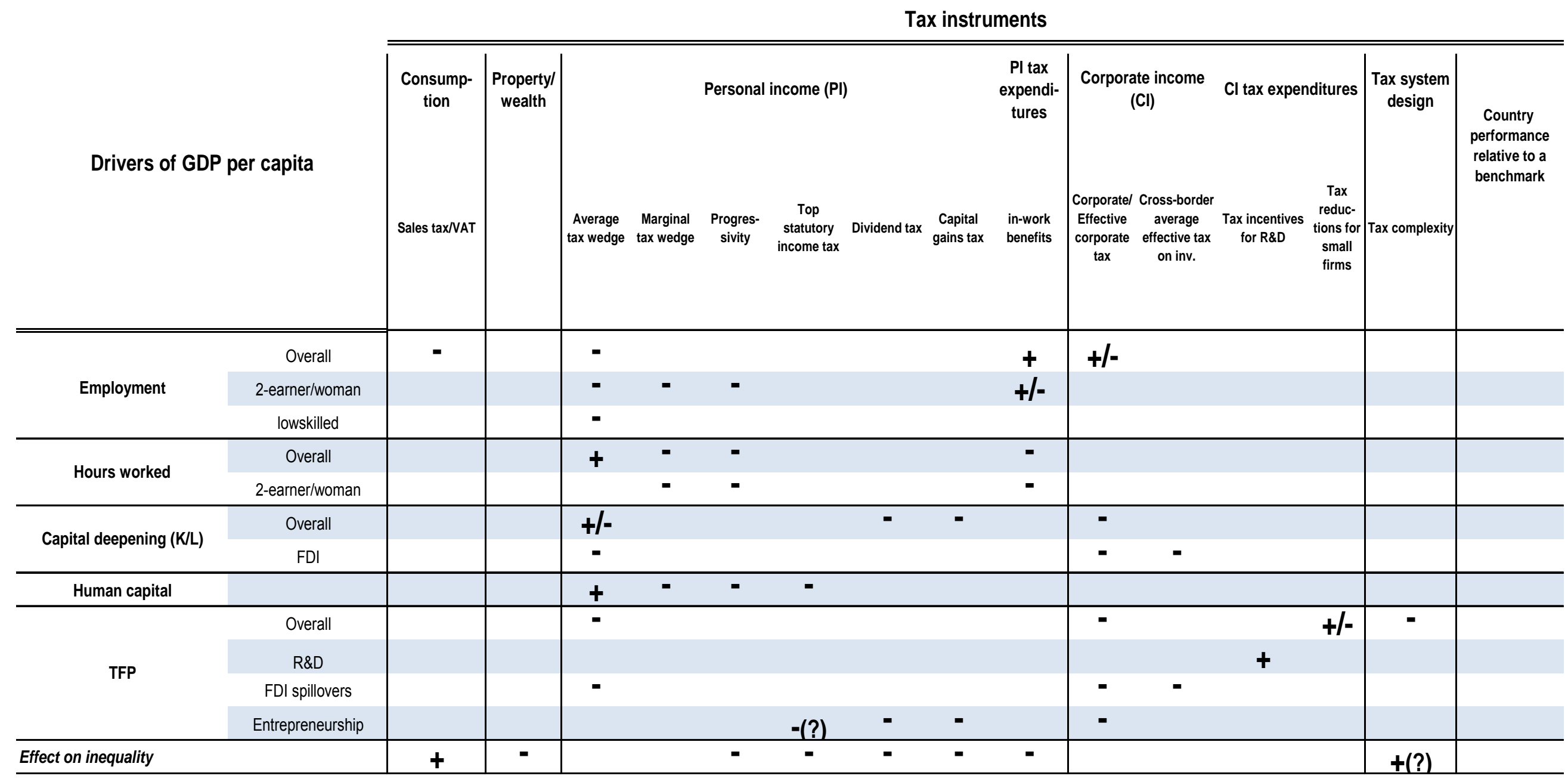


ECO/WKP(2008)28

\section{ANNEX 2: DESCRIPTION OF TAX INDICATORS}

\section{Tax revenue and tax mix}

\section{Total tax revenue as percentage of GDP}

Tax revenue of major taxes as a percentage of Gross Domestic Product (GDP) at market prices: personal income tax, corporate income tax, employees' and employers' social security contributions, taxes on payroll and workforce, property taxes, general consumption taxes, specific consumption taxes (excise taxes, import duties, environmental taxes).

Source: Revenue Statistics, OECD

\section{$\operatorname{Tax} \operatorname{mix}$}

The government's choice of how much revenue to raise from the different major taxes.

Source: Revenue Statistics, OECD

\section{Labour taxes}

\section{Statutory personal income tax rates}

Central plus sub-central tax rates applicable to personal labour income, taking into account any relief given at a higher level of government for taxes paid at a lower level.

Source: Taxing Wages, OECD Tax Database

Average tax wedge

The average tax wedge is the difference between total labour costs to the employer and the corresponding net take-home pay of the employee. It is calculated by expressing the sum of personal income tax, employees' plus employers' social security contributions together with any payroll tax less cash benefits, as a percentage of total labour costs, defined as the wage plus employers' social security contribution and payroll taxes.

Source: Taxing Wages, OECD Tax Database

\section{Marginal tax wedge}

The marginal tax wedge is the percentage of any small rise in labour costs that ends up as government revenue through the personal income tax and both employees' and employers' social security contributions and payroll taxes.

Source: Taxing Wages, OECD Tax Database 
(All-in) Top marginal rate of personal income tax

Additional central and sub-central government personal income tax, plus employee social security contribution, resulting from a unit increase in gross wage earnings. This rate is calculated at the income level where the top statutory rate first applies.

Source: OECD Tax Database

Progressivity of the personal income tax system

Rate at which the income tax burden increases with income. The measure of progressivity used in this report is the difference between the marginal and average personal income tax rates, divided by one minus the average personal income tax rate, for an average single production worker. A higher number indicates higher progressivity.

Source: Taxing Wages, OECD Tax Database

\section{Capital Taxes}

\section{(Standard) Statutory corporate tax rate}

Central plus sub-central (non-targeted) tax rate levied on corporate profits, taking into account any relief given at a higher level of government for taxes paid at a lower level. This is the rate which applies to the majority of corporations. Where a progressive (as opposed to flat) rate structure applies, the top marginal rate is used.

Source: OECD Tax Database

\section{Targeted or reduced combined corporate rate for small business}

Central government corporate rate plus the sub-central rate (net rate where the central government provides a deduction in respect of sub-central income tax) typically applying for or targeted at 'small (incorporated) business', where such 'targeting' is on the basis of size alone (e.g. number of employees, amount of assets, turnover or taxable income) and not on the basis of expenditures or other targeting criteria.

A 'small business corporate tax rate' may be a special statutory corporate tax rate applicable to (all or part of) the taxable income of qualifying 'small' firms (e.g. meeting a turnover, income, or asset test), or an effective corporate tax rate below the basic statutory corporate rate provided through a tax deduction or credit for 'small' firms determined as a percentage of qualifying taxable income (e.g. up to a given threshold). These reduced rates are intended to reduce the effect of corporate taxation on the investment of these corporations.

Source: OECD Tax Database

Tax capital depreciation allowances

Present value of deductions from taxable income due to depreciation of capital over time.

Source: Institute for Fiscal Studies (IFS). 
ECO/WKP(2008)28

\section{Average effective tax rate}

The average effective tax rate (AETR) measures the impact of corporate taxation on investments as the proportion of the pre-tax economic profit taken by the government; i.e. the AETR measures how taxation affects the net present value of a firm for a given pre-tax rate of return. It takes into account not only the statutory corporate tax rate but also other aspects of the tax code such as, for example, depreciation allowances. It is a forward-looking measure in the sense that it computes the net present value of a hypothetical potential investment in the presence and absence of tax.

Source: Institute for Fiscal Studies (IFS).

\section{Marginal effective tax rates}

The marginal effective tax rate (METR) measures the impact of taxation on marginal investments under the assumption that all potential investment projects earn at least the cost of capital; i.e. the minimum pretax rate of return on an investment required by the investor (marginal finance rate of return). It takes into account not only the statutory corporate tax rate but also other aspects of the tax code such as, for example, depreciation allowances. It is a forward-looking measure in the sense that it computes the net present value of a hypothetical potential investment in the presence and absence of tax, in contrast to use actual data on tax revenues or the tax liabilities of firms (backward-looking measures).

Source: Institute for Fiscal Studies (IFS).

\section{Cross-border average effective tax rates}

The cross-border average effective tax rate measures the impact of corporate taxation on cross-border investments as the proportion of the pre-tax economic profit taken by the host and home governments. It takes into account different aspects of home and host countries tax codes that are relevant for foreign direct investment (FDI) decisions by multinational enterprises (MNEs) such as home/host statutory corporate tax rates, withholding taxes, depreciation allowances in the host country, tax treatment of foreign source income in the home country. It is a forward-looking measure in the sense that it computes the net present value of a hypothetical potential investment in the presence and absence of tax, in contrast to use actual data on tax revenues or the tax liabilities of firms.

Source: Yoo, 2003.

\section{Overall taxation of dividend income}

Effective corporate plus personal tax rate on distributed profit calculated as:

[(pre-tax distributed profits - distributed profits + net personal tax $) /$ pre-tax distributed profits $]^{*} 100$;

where:

For a distribution of 100 , the distributed pre-tax profit is calculated as $100 /(1-u)$ where $u$ denotes the corporate income tax rate on distributed profits.

The net personal tax is defined as the net top statutory rate to be paid at the shareholder level, taking account of all types of reliefs and gross-up provisions at the shareholder level.

Source: OECD Tax Database 


\section{$R \& D$ tax subsidies / incentives}

Tax subsidies for $R \& D$ include $R \& D$ tax credits that are deductible from taxable income, and investment and depreciation allowances that are deductible from tax liability. To measure the generosity of R\&D tax subsidies, this report employs a measure of R\&D tax treatment called the B-index (Warda, 2006). The Bindex measures the minimum value of before-tax income that a firm needs to cover the cost of R\&D investment where the cost is standardized to one dollar. R\&D tax subsidies are determined as one minus the B-index which captures the tax subsidy per dollar invested in R\&D. Negative values do not necessarily imply that $R \& D$ is not taxed favourably but only imply that $R \& D$ receives a tax treatment that is less generous than would be the case under full immediate expensing.

Source: OECD Science, Technology and Industry Scoreboard.

\section{Consumption taxes}

\section{C-efficiency for VAT}

The C-efficiency ratio for VAT is a measure of the broadness of the tax base, the extent of the use of reduced rates and of the effectiveness with which taxes are collected. It expresses the revenue collected from the actual VAT in a country as a proportion of the revenue that would be raised if the main rate of VAT were applied to all consumption. A high ratio suggests a uniformly applied VAT on a broad base with effective tax collection while a low ratio may indicate an erosion of the tax base either by exemption or reduced rates, poor compliance or poor tax administration or a combination of these.

Source: OECD Tax Database; OECD Consumption Tax Trends (2006) 
ECO/WKP(2008)28

\section{BIBLIOGRAPHY}

Abramovsky, L., R. Griffith and R. Harrisson (2005), "Background Facts and Comments on 'Supporting Growth in Innovation: Enhancing the R\&D Tax Credit'", IFS Briefing Note, No. BN68, Institute for Fiscal Studies, London.

Adam, S., M. Brewer and A. Shephard (2006a), "Financial Work Incentives in Britain: Comparison over Time and between Family Types", IFS Working Paper, No. W06/20, Institute for Fiscal Studies, London.

Adam, S., M. Brewer and A. Shephard (2006b), The Poverty Trade-off: Work Incentives and Income Redistribution in Britain, Jospeh Rowntree Foundation, New York.

Adema, W and M. Ladaique (2005), 'Net Social Expenditure, 2005 Edition”, OECD Social, Employment and Migration Working Papers No. 29.

Alesina, A., S. Ardagna, G. Nicoletti and F. Schiantarelli (2005a), "Regulation and Investment", Journal of the European Economic Association, June 2005, 3: pp.791-825.

Alesina, A., E. Glaeser and B. Sacerdote (2005b), "Work and Leisure in the US and Europe: Why So Different?”, NBER Working Paper No. 11278.

Antolin, P, A. de Serres, and C. de la Maisonneuve (2004), "Long-Term Budgetary Implications of TaxFavoured Retirement Saving Plans", OECD Economic Studies No. 39, 2004/2.

Arnold, J. (2008), "Do Tax Structures Affect Aggregate Economic Growth? Empirical Evidence from a Panel of OECD Countries", OECD Economics Department Working Papers, forthcoming.

Auerbach, A.J. (2002), “Taxation and Corporate Financial Policy”, in Auerbach, A.J. and M. Feldstein (eds.), Handbook of Public Economics Vol. 3, Elsevier, North-Holland.

Auerbach, A.J. (2006), “The Future of Capital Income Taxation”, Fiscal Studies, Vol. 27, no. 4.

Barker, K. (2006), “Delivering Stability: Securing our Future Housing Needs”, Barker Review of Housing Supply - Final Report, available at: www.barkerreview.org.uk.

Bassanini, A. and R. Duval (2006), "Employment Patterns in OECD Countries: Reassessing the Role of Policies and Institutions, OECD Economics Department Working Papers, No. 486.

Bloom, N., R. Sadun and J. van Reenen (2007), “Americans Do I.T. Better: US Multinationals and the Productivity Miracle”, NBER Working Paper, No. 13085, National Bureau of Economic Research, Cambridge MA.

Blundell, R., A. Duncan and C. Meghir (1998), "Estimating Labor Supply Responses Using Tax Reforms” Econometrica, Vol 66. 
Blundell, R., A. Duncan, J. McCrae,. and C. Meghir (2000), "The Labour Market Impact of the Working Families' Tax Credit." Fiscal Studies, 2000, 21(1), pp. 75-103.

Blundell, R. and T. MaCurdy (1999), "Labor Supply: A Review of Alternative Approaches" in O. Ashenfelter and R. Layard (eds.), Handbook of Labor Economics, Vol. 3A, Amsterdam, North Holland.

Boersch-Supan, A. (1998). "Capital's Contribution to Productivity and the Nature of Competition", Brookings Papers on Economic Activity, Microeconomics.

Brandt, N. (2005), "Business Dynamics and Policies", OECD Economic Studies No. 38, 2004/1.

Causa, O. (2008), "Explaining Differences in Hours Worked Among OECD Countries: An Empirical Analysis", OECD Economics Department Working Papers No. 596.

Card, D. and P.K. Robins (1998), "Do Financial Incentives Encourage Welfare Recipients to Work?" Research in Labor Economics, 17, pp. 1-56.

Conway. P, D. De Rosa, F. Steiner and G. Nicoletti (2006)" Regulation, Competition and Productivity Convergence", OECD Economic Studies No. 43/2 2006.

Corlett, W.J. and D.C. Hague (1953) "Complementarity and the Excess Burden of Taxation." Review of Economic Studies 21.

Criscuolo, C. (2006), "Foreign Affiliates in OECD Economies: Presence, Performance and Contribution to Host Countries' Growth", OECD Economic Studies No. 41, 2005/2.

Crawford, C. and J. Freedman (2007), "Small Business Taxation: A Special Study in Selected Issues Undertaken for the Mirlees Review", Mimeo.

Dahlby, B. (2003), "Restructuring the Canadian Tax system by Changing the Mix of Direct and Indirect Taxes", Tax Reform in Canada: Our Path to Greater Prosperity.

Daveri, F. and T. Tabellini (2000), "Unemployment and Taxes: Do Taxes Affect the Rate of Unemployment?”, Economic Policy.

Deaton, A. and N. Stem (1986), "Optimally Uniform Commodity Taxes, Taste Differences and Lump-Sum Grants”, Economic Letters, Vol. 20, pp.263-6.

Devereux, M.P. and P.B. Sorensen (2006), “The Corporate Income Tax: International Trends and Options for Fundamental Reform, European Commission, Economic Papers No. 264.

Devereux , M.P. and R. Griffith (2003), "Evaluating Tax Policy for Location Decisions”, International Tax and Public Finance, 10, pp.107-126.

Diamond, P.A. and J.A. Mirrlees (1971), “Optimal Taxation and Public Production", American Economic Review, Vol. 61.

Disney, R. (2004), “Are Contributions to Public Pension Programmes a Tax on Employment?”, Economic Policy.

Ebrill, L., M. Keen, J-P. Bodin and V. Summers (2001), “The Modern VAT”, IMF. 
European Commission (2006), "Macroeconomic Effects of a Shift from Direct to Indirect Taxation: Simulation for 15 EU Member States", Note presented at WP2 in November 2006.

Evers, M., R.A. de Mooij and D.J. van Vuuren (2006), "What Explains the Variation in Estimates of Labour Supply Elasticities?", Tinbergen Institute Discussion Paper 2006-017/3.

Feldstein, M. (2006), “The Effect of Taxes on Efficiency and Growth”, NBER Working Paper, No. 12201, NBER, Cambridge.

Gentry, W. and R.G. Hubbard (2000), "Tax Policy and Entrepreneurial Entry”, American Economic Association Papers and Proceedings, Vol. 90, No. 2, May 2000.

Gordon, R.H., and J.R. Hines, Jr. (2002). “International Taxation”, NBER Working PaperNo 8854.

Griffith, R., S. Redding and H. Simpson (2006), 'Technological Catch-Up and the Role of Multinationals," revised version of CEPR Discussion Paper No. 3765.

Griffith, R., S. Redding and H. Simpson (2004), "Foreign Ownership and Productivity: New Evidence from the Services Sector and the R\&D Lab", CEP Discussion Paper, No. 649, Centre for Economic Performance, London.

Guellec, D. and B. van Pottelberghe (2000), OECD Science, Technology and Industry Working Papers $2000 / 4$.

Guhl, N. and D. Hughes (2006), "Cigarette Smoking and Market Failure: A Determination of the Economically Efficient Cigarette Tax Rate, B>Quest research articles.

Hajkova, D., G. Nicoletti, L. Vartia and K.Y. Yoo (2006), "Taxation and Business Environment as Drivers of Foreign Direct Investment in OECD Countries”, OECD Economic Studies No. 43/2 2006.

Hall, R.E., and D. Jorgenson (1967), "Tax Policy and Investment Behavior." American Economic Review, Vol. 57.

Hall, R.E (1988), “Intertemporal Substitution in Consumption”, Journal of Political Economy, 96.

Heady, C. (1987), "A Diagrammatic Approach to Optimal CommodityTtaxation", Public Finance, 42 (1987), 250-263.

Heckman, J. (1993) "What Has Been Learned About Labor Supply In The Past Twenty Years?," American Economic Association Papers and Proceedings, (May 1993), 83(2), 116-121.

Immervoll, H. and D. Barber (2005), "Can Parents Afford to Work? Childcare Costs, Tax-Benefit Policies and Work Incentives", OECD Social, Employment and Migration Working Papers No. 31.

International Tax Dialogue (2007), "Taxation of Small and Medium Enterprises", Background paper for the International Tax Dialogue Conference, Buenos Aires, October 2007, available at: http://www.itdweb.org/smeconference/documents/itd\%20global\%20conference\%20\%20background\%20paper.pdf

Jaumotte, F., and N. Pain (2005a), "From Ideas to Development: the Determinants of R\&D and Patenting", OECD Economics Department Working Papers, No. 457. 
Jaumotte, F. and N. Pain (2005b), "Innovation in the Business Sector", OECD Economics Department Working Papers, No. 459.

Jaumotte, F. (2003), "Female Labour Force Participation : Past Trends and Main Determinants in OECD Countries", OECD Economics Department Working Papers, No. 376.

Jeanrenaud, C. and N. Soguel (Ed.) (1999): "Valuing the Cost of Smoking: Assessment Methods, Risk Perception and Policy Options, " Studies in Risk and Uncertainty, V35, Kluwer Academic Publishers, Norwell, MA.

Joumard, I. and. P.M. Kongsrud (2003), "Fiscal Relations Across Government Levels", OECD Economics Department Working Paper No. 375.

Keller, W. (2004), "International Technology Diffusion", Journal of Economic Literature, Vol. 42, No. 3.

Klevmarken, N.A. (2000), "Did the Tax Cuts Increase Hours of Work? A Statistical Analysis of a Natural Experiment", KYKLOS, 53, 337-362.

Koskela, E. (2002), "Labour Taxation and Employment in Trade Union Models: A Partial Survey", in S Ilmakunnas ans E. Koskela (eds), Towards Higher Employment: The Role of Labour Market Institutions, Helsinki.

Layard. R., S. Nickell and R. Jackman (1996) “Combatting Unemployment: Is Flexibility enough?” In OECD: Macroeconomic Policies and Structural Reform, Paris.

Layard, R.,S. Nickell and R. Jackman (1991), Unemployment: Macroeconomic Performance and the Labour Market, Oxford University Press.

Meghir, C. and D. Phillips (2007), "Labour Supply and Taxes”, Mimeo.

Meyer, B.D. and D.T. Rosenbaum (2001) "Welfare, the Earned Income Tax Credit, and the Labor Supply of Single Mothers." Quarterly Journal of Economics, 117(3), pp. 1063-1114.

de Mooij, R.A. and G. Nicodème (2007), "Corporate Tax Policy and Incorporation in the EU", Working Papers CEB 07-016.RS, Université Libre de Bruxelles, Solvay Business School, Centre Emile Bernheim (CEB).

Myles, G. (2008), "Economic Growth and the Role of Taxation", OECD Economics Department Working Papers, (forthcoming).

Nickell, S. (2004), “Employment and Taxes”, CEP Discussion Paper, No. 634.

Nickell, S.J., L. Nunziata, W. Ochel and G. Quintini (2003), “The Beveridge Curve, Unemployment and Wages in the OECD from the 1960s to the 1990s", in P. Aghion, R. Frydman, J. Stiglitz and M. Woodford (eds.), Knowledge, Information and Expectations in Modern Macroeconomics: In Honor of Edmund S. Phelps, (Princeton: Princeton University Press).

OECD (1995), Transfer Pricing Guidelines for Multinational Enterprises and Tax Administrations, OECD, Paris.

OECD (2004), Economic Studies, Special Issue: Tax-favoured retirement saving, OECD Economic Studies No. $39,2004 / 2$. 
OECD (2005a), "How Persistent are Regional Disparities in Employment?", Chapter 2, OECD Employment Outlook.

OECD (2005b), OECD Jobs Strategy: Lessons from a Decade's Experience, Main Report, $\mathrm{ECO} / \mathrm{CPE} / \mathrm{WP} 1(2006) 1$.

OECD (2005c), Taxing Working Families: A Distributional Analysis, OECD Tax Policy Studies No. 12.

OECD (2006a), Consumption Tax Trends, VAT/GST and Excise Rates, Trends and Administration Issues, OECD 2006.

OECD (2006b), Fundamental Reform of Personal Income Tax, OECD Tax Policy Studies No. 13.

OECD (2006c), Taxation of Capital Gains of Individuals: Policy Considerations and Approaches, OECD Tax Policy Studies No. 14.

OECD (2006d), The Political Economy of Environmentally Related Taxes, OECD.

OECD (2007a), "Financing Social Protection: the Employment Effect", Chapter 4, OECD Employment Outlook.

OECD (2007b), Fundamental Reform of Corporate Income Tax, OECD Tax Policy Studies No. 16.

OECD (2007c), Tax Effects on Foreign Direct Investment: Recent Evidence and Policy Analysis, OECD Tax Policy Studies No. 17.

OECD (2007d), OECD Revenue Statistics.

OECD (2007e), “Going for Growth”, Economic Policy Reforms, OECD.

OECD (2007f), "Factors Explaining Differences in Hours Worked Across OECD Countries", ECO/CPE/WP1(2007)11.

Oliveira Martins J., R. Boarini, H. Strauss, C. de la Maisonneuve and and C. Saadi (2007), "The Policy Determinants of Investment in Tertiary Education", OECD Economics Department Working Papers, No. 576 .

Pissarides, C. (1998), "The Impact of Employment Tax Cuts on Unemployment and Wages: the Role of Unemployment Benefits and Tax Structure", European Economic Review, Vol. 42.

Poterba, J.M. (1989), “Capital Gains Tax Policy towards Entrepreneurship.” National Tax Journal No. 42(3).

Prescott, E. (2004), "Why Do Americans Work So Much More Than Europeans?”, Federal Reserve Bank of Minneapolis Quarterly Review, Vol. 28, pp.2-13.

Rajan, R and L. Zingales (1998), "Financial Dependence and Growth", American Economic Review, 88, 559-586.

Ramsey, F. P. (1927): “A Contribution to the Theory of Taxation.” Economic Journal 37 47-61. 


\section{ECO/WKP(2008)28}

Scarpetta, S. and T. Tressel (2002), "Productivity and Convergence in a Panel of OECD Industries: Do Regulations and Institutions Matter?," OECD Economics Department Working Papers No. 342.

Schwellnus, C. (2008), "Do corporate taxes reduce productivity and investment at the firm-level? Crosscountry evidence from the Amadeus dataset" OECD Economics Department Working Papers, forthcoming.

Slemrod, J., J. Whiting and J. Shaw (2007), "Tax Implementation Issues in the United Kingdom", draft paper prepared for the IFS Conference on "Reforming the Tax System for the 21st Century: The Mirrlees Review", Cambridge, 12 April, available at: www.ifs.org.uk/mirrleesreview/publications.php

Summers, L.H. (1982), “Tax Policy and the Return to Savings”, NBER Working Papers No. 995.

Sørensen, P.B (1998), "Recent Innovations in Nordic Tax Policy: from the Global Income Tax to the Dual Income Tax", in: Tax Policy in the Nordic countries, Macmillan Press.

Yoo, K.-Y. and A. de Serres (2004), Tax Treatment of Private Pension Savings in OECD Countries, OECD Economic Studies, OECD Paris.

Yoo, K.-Y. (2003), “Corporate Taxation of Foreign Direct Investment Income 1991-2001”, OECD Economics Department Working Papers No .365.

Vartia, L. (2008), "How Do Taxes Affect Investment and Productivity? - Industry Level Analysis of OECD Countries", OECD Economics Department Working Papers, forthcoming. 
ECO/WKP(2008)28

\section{WORKING PAPERS}

The full series of Economics Department Working Papers can be consulted at www.oecd.org/eco/Working_Papers/

619. Coping with labour shortages: How to bring outsiders back to the labour market (July 2008) Ekkehard Ernst

618. Achieving sustainability of the energy sector in Canada (June 2008) Annabelle Mourougane

617. The Dutch tax-benefit system and life-cycle employment. Outcomes and reform options (June 2008) Ekkehard Ernst and Timo Teuber

616. Regulation, Allocative Efficiency and Productivity in OECD Countries: Industry and Firm-Level Evidence

(May 2008) Jens Arnold, Giuseppe. Nicoletti, and Stefano Scarpetta

615. Public social spending in Korea in the context of rapid population ageing (May 2008) Randall S. Jones

614. Enhancing the globalisation of Korea (May 2008) Randall S. Jones and Taesik Yoon

613. Reforming housing and regional policies in Korea (May 2008) Randall S. Jones and Tadashi Yokoyama

612. Moving towards more sustainable healthcare financing in Germany (May 2008) N. Brandt

611. Improving education outcomes in Germany (May 2008) David Carey

610. Have developed countries escaped the curse of distance? (May 2008) Hervé Boulhol and Alain de Serres

609. Measures of international transport cost for OECD countries $\mid$ (April 2008) Stephen S. Golub and Brian Tomasik

608. Encouraging labour force participation in Chile (April 2008) D. Contreras, L. de Mello and E. Puentes

607. Tackling business and labour informality in Chile (April 2008) D. Contreras, L. de Mello and E. Puentes

606. Delivery cost-efficient public services in health care, education and housing in Chile (April 2008) D. Contreras, L. de Mello and E. Puentes

605. Managing Chile's macroeconomy during and after the copper price boom (April 2008) Luiz de Mello 
604. Avoiding the value added tax: Theory and cross-country evidence (April 2008) Luiz de Mello

603. Oil Price Shocks, Rigidities and the Conduct of Monetary Policy: Some Lessons from a New Keynesian Perspective (April 2008) Romain Duval and Lukas Vogel

602. The Contribution of Economic Geography to GDP Per Capita (April 2008) Hervé Boulhol, Alain de Serres and Margit Molnar

601. Estimating a supply block for Poland (April 2008) Rafal Kierzenkowski, Patric Ollivaud, Franck Sédillot and Philippe Briard

600. Product market regulation and economic performance across Indian states (March 2008) Paul Conway, Richard Herd and Thomas Chalaux

599. Improving product market regulation in India: an international and cross-state comparison (March 2008) Paul Conway and Richard Herd

598. Revenue buoyancy and its fiscal policy implications (February 2008) Isabelle Joumard and Christophe André

597. Monetary policy, market excesses and financial turmoil (February 2008) Rudiger Ahrend, Boris Cournède and Robert Price

596. Explaining differences in hours worked among OECD countries: an empirical analysis (February 2008) Sven Blondal and Jean-Marc Burniaux

595. Fiscal policy in India: past reforms and future challenges (February 2008) Richard Herd and Willi Leibfritz

594. The significance of Switzerland's enormous current-account surplus (March 2008) Peter Jarrett and Céline Letremy

593. Interdependencies between monetary policy and foreign-exchange intervention under inflation targeting: the case of Brazil and the Czech Republic (January 2008) Jean-Yves Gnabo, Luiz de Mello and Diego Moccero

592. Solow or Lucas? Testing growth models using panel data from OECD countries (December 2007) Jens Arnold, Andrea Bassanini and Stefano Scarpetta

591. The private internal rates of return to tertiary education: new estimates for 21 OECD countries (December 2007) Romina Boarini and Hubert Strauss.

590. Making federalism work (December 2007) Alexandra Bibbee

589. The wage premium on tertiary education: New estimates for 21 OECD countries (December 2007) Hubert Strauss and Christine de la Maisonneuve 